\title{
1991 OCRWM Bulletin Compilation and Index
}

May 1992

U.S. Department of Energy

Office of Civilian Radioactive Waste Management

Washington, DC 20585 


\section{DISCLAIMER}

This report was prepared as an account of work sponsored by an agency of the United States Government. Neither. the United States Government nor any agency thereof, nor any of their employees, make any warranty, express or implied, or assumes any legal liability or responsibility for the accuracy, completeness, or usefulness of any information, apparatus, product, or process disclosed, or represents that its use would not infringe privately owned rights. Reference herein to any specific commercial product, process, or service by trade name, trademark, manufacturer, or otherwise does not necessarily constitute or imply its endorsement, recommendation, or favoring by the United States Government or any.agency thereof. The views and opinions of authors expressed herein do not necessarily state or reflect those of the United States Government or any agency thereof. 


\section{DISCLAIMER}

Portions of this document may be illegible in electronic image products. Images are produced from the best available original document. 


\section{Introduction}

The OCRWM Bulletin is published by the Department of Energy, Office of Civilian Radioactive Waste Management, to provide current information about the national program for managing spent fuel and high-level radioactive waste. This document is a compilation of issues from the 1991 calendar year. A table of contents and an index have been provided to reference information contained in this year's Bulletins. Consecutive page numbers can be found at the bottom of each page.

\section{Table of Contents}

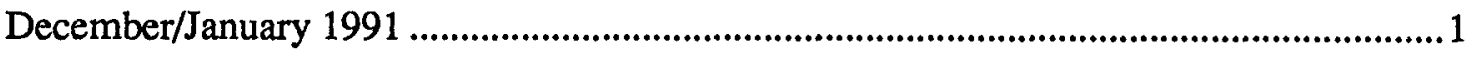

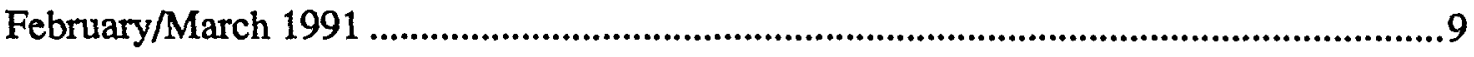

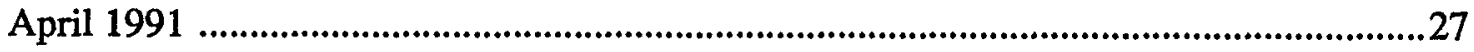

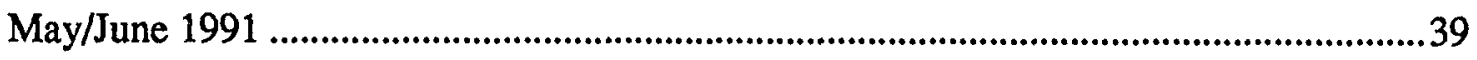

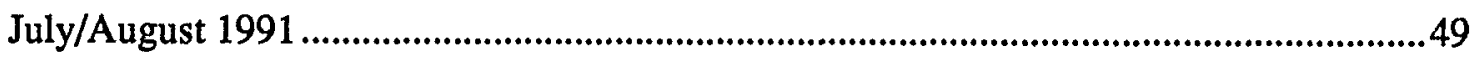

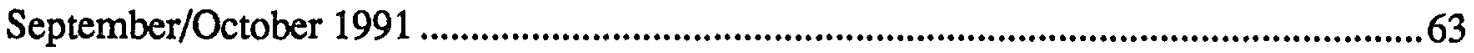

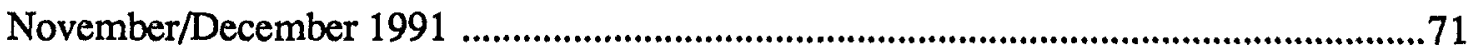

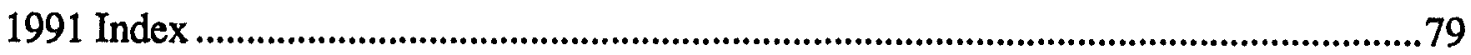




\section{OCRWM Bulletin}

United States Department of Energy

Office of Civilian Radioactive Waste Management

Washington, DC 20585

December 1990IJanuary 1991

\section{DOE Issues Assessment of Nuclear Waste Fund Fee Adequacy}

In December 1982, Congress passed the Nuclear Waste Policy Act (NWPA) which included a direction that a fee of 1.0 mill per kilowatt-hour ( $\mathrm{kWh}$ ) of electricity generated and sold by a nuclear utility shall be collected into a NWF to pay the full costs of the program to dispose of civilian nuclear waste. In addition, DOE would pay its fair share of the costs to permanently dispose of the high-level radioactive waste generated by its weapons production activities.

Through Fiscal Year (FY) 1989, approximately $\$ 4.0$ billion has been paid by the utilities into the NWF. The NWF has earned $\$ 609$ million on interest on investments in Government securities through FY 1989. At the end of FY 1989, the NWF had a balance of $\$ 2.2$ billion. The FY 1990 financial figures are currently being audited. The unaudited NWF balance for FY 1990 is $\$ 2.6$ billion.

It is to be expected that the NWF will exhibit a large positive balance when program expenses are low. The fund balance is presently estimated to peak in the mid-2020s, and then decline steadily to zero at the end of the repository decommissioning about the year 2075 .

Congress anticipated the potential need at some time in the life of the program for changing the 1.0 mill per $\mathrm{kWh}$ fee, and provided a method for recommending a change. DOE has recognized in previous fee adequacy reports that the fee may need to be increased at some time in the future.

DOE's policy is to conduct a thorough analysis annually, and to recommend a change in the fee when there is a compelling case for the change. Two methods have been considered by DOE for adjusting the fee when necessary. They are (1) indexing to inflation and (2) less frequent step adjustments. DOE's preferred method for changing the fee is the step adjustment. This method provides for a change in the fee based upon programmatic as well as economic factors, and requires DOE to fully justify each fee change proposed.

DOE's current evaluation, the sixth in a series of fee adequacy reports, considers all program changes that have taken place since the last report was published in June 1987. In making this evaluation, analyses were made of a variety of scenarios involving construction of either one or two repositories, and various inflation rate projections. Based on the findings in the analysis for a base-case scenario utilizing an inflation rate of 4 percent and a real interest rate of 3 percent, DOE does not find a compelling case for recommending a fee adjustment at this time. The report, "Nuclear Waste Fund Fee Adequacy: An Assessment," DOE/ RW-0291P, contains the methodology, assumptions and analyses supporting this conclusion. A copy of this report is available on request by calling (202) 586 5722 or by writing to the U.S. Department of Energy, OCRWM (RW5.1), 1000 Independence Avenue, S.W., Washington, DC 20585.

\section{In This Issue}

DOE Issues Assessment of Nuclear Waste Fund Fee Adequacy

DOE and Office of Nuclear Waste Negotiator Sign Memorandum of Understanding

Nuclear Waste Technical Review

Board Issues Its Second Report to Congress and the Secretary of Energy

OCRWM Holds Workshops on Waste Management Policies and Strategic Principles

Senior Staff Meet with Foreign Counterparts for Radioactive Waste Management Committe for Radioactive Waste Management
and Bilateral Agreement Meetings

DOE Issues Progress Report on the Scientific Investigation Program for the Nevada Yucca Mountain Site

New Publications and Documents

DOE Holds Project Update Meetings in Nevada

Transportation Coordination Group Meets in Albuguerque, NM

Selected Events Calendar

NOTE TOREADERS:The OCRWMBulletin is avaiblable to users of INFOLINKII about one week before publication. To beplaced on the mailing list, to make any address corrections, or to request multiplo copies of the OCRWM Bulletin, please contact Judy Hockenberry, MA-234-2, DOE, Germantown Building, Weshington, DC 20545, (301) 353-3118. 


\section{DOE and Office of Nuclear Waste Negotiator Sign Memorandum of Understanding}

The Office of the Nuclear Waste Negotiator (ONWN), an independent office in the Executive Branch, was established by amendments to the Nuclear Waste Policy Act in 1987. The mission of ONWN is to attempt to reach a proposed agreement between the United States and a State or Indian Tribe willing to host a monitored retrievable storage facility or a permanent repository within their jurisdiction as part of an integrated waste management system for the disposal of spent nuclear fuel and highlevel radioactive waste.
On November 29,1990 , the Negotiator and the Secretary of Energy signed an initial Memorandum of Understanding (MOU) that specifies the working relationship and points of contact between the two organizations. This agreement facilitates the use of DOE services, personnel, facilities, and information in furtherance of the objectives of ONWN while maintaining the integrity and inde-pendence of both organizations. DOE intends to cooperate fully with the ONWN, in accordance with the Secretary's rights and responsibilities under the amended NWPA.

Subsequent MOUs may be entered into at a later date regarding other provisions of the NWPA, as amended, addressing such matters as the environmental assessment of potential sites for a monitored retrievable storage facility or a permanent repository, and financial assistance grants to potential host jurisdictions to assess the feasibility of siting a monitored retrievable storage facility.

\section{Nuclear Waste Technical Review Board Issues lts Second Report to Congress and the Secrefary of Energy}

Congress created the Nuclear Waste Technical Review Board (NWTRB) in 1987 to evaluate the scientific and technical validity of activities undertaken by DOE in its civilian high-level nuclear waste disposal program. In accordance with the requirements of the amended NWPA, the NWTRB submitted its second report to Congress and DOE Secretary Watkins on November 27, 1990. This report contains the following recommendations:

Effects of seismicity and faulting on facility design and site suitability

1. Increasedemphasis shouldbeplaced on understanding the engineering, public safety, and environmental consequences of seismic events at Yucca Mountain, including earthquakes of magnitudes larger than those that are likely to occur during the lifetime of the facility.

2. Discussions of site suitability should be based on the likelihood of adverse consequences and not on the occurrence of earthquake ground motion or fault displacement alone.

3. Formulation of a specific tectonic model, acceptable with ahigh degree of confidence, should not be viewed as prerequisite to site suitability or to ensuring public safety and environmental protection.

4. Geologic licensing criteria and standards for the repository and its surface facilities should reflect the nature and relative vulnerability of the repository complex and the problems it poses. The criteria and standards should ensure public safety and environmental protection in the light of current scientific knowledge and engineering practice, including the feasible mitigation of adverse consequences.

\section{Testing for site suitability}

5. Planned scientific testing of the Yucca Mountain geologic block should be re-evaluated to give highest priority to those tests and studies that provide the data essential to assess the suitability of the site. Each proposed study should be evaluated in terms of procedures, technologies, test locations, and appropriateness in meeting stated objectives.
6. The DOE should consider expanding its development program for dry-drilling equipment to include the capability to drill inclined holes.

\section{Performance Assessment}

7. The DOE should continue using decision-aiding methodology to provide more explicit and formal means for relating program decisions to risk and performance issues. Such issues should be used in an iterative and ongoing fashion to explain the reasoning behind major programmatic decisions before these decisions are committed. The four existing DOE task force studies applying these methods should be closely coordinated.

8. The DOE should continue to develop methods for assessing expert judgment in areas of significant uncertainty. Furthermore, the DOE should incorporate into the current task force studies the views of technical experts outside the DOE and its contractors. The basis for each expert judgment needs to be carefully documented.

(continued on page 3) 


\section{Nuclear Waste Technical Review Board Issues lts Second Report to Congress and the Secretary of Energy}

(continued from page 2)

9. The DOE should consider investigating more extensively the use of natural analogues to support performance assessment for a potential repository at the Yucca Mountain site.

\section{Long'lived waste packages}

10. At a future meeting, the $D O E$ should respond to the Engineered Barrier System (EBS) Panel's four questions of January 6,1990 , relating to EBS performance. It should be emphasized that the NWTRB interest in a robust, extended-life EBS does not imply a diminished interest in the geologic barrier's contribution to overall repository performance; rather, the Board is suggesting engineered barriers may reduce the adverse consequences associated with difficult-to-predict geologic or climatological events.

11. A workshop should be held to investigate the practicality, advantages, and disadvantages of developing a robust, extended-life EBS that would contribute to containment for periods of time well beyond 1,000 years. The NWTRB would be pleased to assist in developing an agenda for such a workshop.

Waste container materials, configurations, and disposal environments

12. Studies of alternative materials should be restarted. These studies should include evaluation of container materials and designs, emplacement designs, and container configurations, including both internal absorbing materials and external back-fill materials.
13. Heater tests should be reinitiated. These tests should examine the effects of alternative emplacement orientations and three-dimensional and multiple heat sources for a range of thermal loads.

14. The EBS development and testing program should be coordinated and funded at a level sufficient to produce a statistical basis for assessing its contribution to longterm predictions of repository. behavior. Tests should be longterm, preferably exceeding five years, and include both laboratory and field testing.

\section{Coordination and integration of environmental studies}

15. The DOE should continue to include in its study plans the interests and concerns of Native Americans, the States of California and Nevada, the National Park Service, the Soil Conservation Service, and the U.S. Fish and Wildlife Service.

16. The DOE and the State of Nevada should explore the possibility of initiating a cooperative program to develop baseline environmental information.

17. All environmental programs at the Yucca Mountain site funded by the Nuclear Waste Fund should be developed and conducted in a manner that the data obtained are appropriate to and can be used during licensing.

18. An integrated environmental program that takes cognizance of ecosystem processes should be developed for the Yucca Mountain

‥ . site. The results of this program should permit assessment of the effects of site characterization and repository construction and operation on the local ecosystem. The program should also provide a basis for understanding ecologic pathways for any radioactive materials that might escape containment during repository construction, operation, and decommissioning.

Human factors and system safety in transportation and handling of spent fuel

19. The NuclearRegulatory Commission should develop policy statements, program guidelines, and, iffeasible, criteria documents in human factors and system safety engineering that will help ensure that the DOE's and utilities' system acquisition programs address future accident potentials. The goal should be for the system acquisition programs to be complete in all the technologies that can contribute to operational safety and efficiency including emergency and mitigation planning.

20. Priority should be placed on developing a high-level waste management system that minimizes handling of spent fuel.

In its concluding perspectives, the NWTRB expressed its pleasure with DOE's efforts to address issues and concerns that the Board has raised. It also indicated that the DOE has made a goodfaith effort to address the recommendations contained in the First Report of NWTRB. OCRWM is currently reviewing the Second Report of NWTRB, and a response is scheduled for May 1991.
古 


\section{OCRWM Holds Workshops on Waste Management Policies and Strategic Principles}

The OCRWM Bulletin for October/ November 1990 announced workshops on waste management policies and strategic principles to be held on December 4-5, 1990, in Salt Lake City, UT, and January 15-16, 1991, in Washington, DC. These workshops are part of DOE's ongoing effort to secure the effective participation by affected and involved parties in the development of waste management policies and strategic principles that will be used for planning, decision making, and to guide program implementation.

The Salt Lake City workshop focused primarily on strategic principles relating to ensuring public safety and protecting the environment. Because of the very productive dialogue that took place during this meeting, a third workshop will be scheduled to inform intcrested parties

\section{Senior Staff Meet with Foreign Counferparts for Radioactive Waste Management Commiftee and Bilateral Agreement Meetings}

During the period September 3 - 13, 1990, Dr. J. W. Bartlett, Director of OCRWM, and Mr.T.H. Isaacs, Director of the Office of Strategic Planning and International Programs, traveled to France, Switzerland, and Sweden for Radioactive Waste Management Committee and Bilateral Agreement meetings.

The purpose of Dr. Bartlett's travel to the Organization for Economic Cooperation and Development/Nuclear Energy Agency (OECD/NEA) in Switzerland and Sweden was to meet with official representatives from other nations to discuss salient fcatures of, and to exchange information relevant to, high-level radioactive waste management programs. In addition, the bilateral agreement meeting with Sweden provided Dr. Bartlett the opportunity to sign an extension of the U.S./Sweden radioactive waste management agreement through September 9, 1995.

Isaacs travelled to France in order to officially represent the United States at the OECD/ NEA Radioactive Waste Management Committee meeting to present U.S. positions on OECD/NEA agenda items and present the current U.S. program status.

Isaacs' travel to Switzerland and Sweden was to represent OCRWM as the Principal Coordinator at the bilateral agreement meetings with the Swiss National Cooperative for the Disposal of Radioactive Waste (NAGRA) and the Swedish Nuclear Fuel and Waste Management Company. The purposes of the bilateral agreement meetings were to: 1) conduct a brief review of each organization's radioactive waste management program; 2) assess current exchange activities and organizational interactions; and 3) to identify, discuss, and record plans for implementation of cooperative activities.

The NAGRA/OCRWM bilateral agreement meeting also provided the opportunity for the U.S. representatives to discuss plans associated with implementation of the latest Project Agreement. Several site visits took place to establish an improved understanding of both Swiss and Swedish programmatic activities for identification-of sites for radioactive waste disposal and underground research. about DOE's response regarding the issues raised at the earlier workshops.

The Washington, DC, workshop, concentrated on the stewardship of resources and the effectiveness of operations. Discussions at this workshop were directed at the specific issues addressing the use of dual purpose casks for transportation and storage, contingency planning, the role of utilities and the Federal Government in the management of spent fuel before disposal, monitored retrievable storagerelated issues, and management issues.

In order to ensure full and free discussion, the workshops are moderated by a neutral facilitator experienced in guiding such public discussions. Participants areasked to speak as individuals rather than as official representatives of specific organizations. Notes are taken for use in further development of strategic principles for the program, but individual participants will not be quoted in written products prepared on the basis of conference discussions. This approach is being taken in order to encourage all parties to express their views at the workshops. 


\section{DOE Issues Progress Report on the Scientific Investigation Program for the Nevada Yucca Mountain Site}

In accordance with the requirements of the amended Nuclear Waste Policy Act, DOE has preparedareporton the progress of scientific investigation activities at Yucca Mountain, NV, from October 1, 1989, through March 31, 1990. This progress report is the second of a series of reports that are issued at intervals of about six months during site characterization. The first progress report was issued in February 1990 (see OCRWM Bulletin, February/March, 1990, for a description). This and future progress reports will be submitted to the Nuclear Regulatory Commission (NRC) and to the Governor and legislature of Nevada. It will also be made available to the Nuclear Waste Technical Review Board, affected units of local government, and the general public.

The progress report provides highlights of work started during the period, work in progress, and work completed and documented during the reporting period. Among the highlights of the report are:

- A formal evaluation of configuration and construction alternatives for the exploratory shaft facility (ESF) was initiated during the October 1989-March 1990 period. The study began by establishing a formal decision methodology to evaluate the relative attributes of various exploratory shaft and ramp configurations at the Yucca Mountain site. In parallel, 17 options for the ESF configuration have been developed that incorporate shafts and ramps at various locations and have been integrated with conceptual layouts for a potential repository at Yucca Mountain.

- In February 1990, the U.S. Fish and Wildlife Service issued a Biological Opinion that scientific investigation activities at Yucca Mountain would not jeopardize the continued existence of the desert tortoise. The Biological Opinion contained specific terms and conditions that the DOE is implementing to minimize the potential effects on the tortoise.

- DOE continued efforts to qualify the quality assurance (QA) programs of OCRWM and participating organizations. Following the November 1989 and March 1990 audits of Los Alamos National Laboratory, OCRWM has determined that all primary participant QA programs are acceptable for further implementation. In addition, all project participant QA Program Plans submitted during the reportingperiod were accepted by the NRC.

- Anew Yucca Mountain Information Office was opened in Las Vegas in March 1990. Both this office and the information office in Beatty, $\mathrm{NV}$, are open daily to the public to provide additional information about the program and scientific investigation activities.

- A report was issued entitled "The Potential Use of Lead in the Waste Package for a Geologic Repository at Yucca Mountain, Nevada" (see OCRWM Bulletin, February/March, 1990, for a description).

- Work continued on the characteristics and behavior of the waste form. Amodel torepresent the stress dependence on the platelet orientation of hydride precipitates was completed.

The report also provides updated schedule information relevant to scientific investigations and a list of documents cited in the text. In addition, the report includes a selective annotated bibliography of recent publications relevant to the scientific investigations. Copies of the reportare available from the U.S. Department of Energy, Office of Scientific and Technical Information, P.O. Box 62, Oak Ridge, TN 37831.

\section{New Publications and Documents}

Nuclear Waste Fund Fee Adequacy: An Assessment, DOE/RW-0291P, November 1990.

This report provides a description of the methodology, assumptions, and analysis used to assess the adequacy of the Nuclear Waste Fund fee. For more details, see article on page 1.

Progress Report on the Scientific Investigation Program for the Nevada Yucca Mountain Site, October 1, 1989 - March 31, 1990, Number 2, DOE/RW-0292P, November 1990.

This report describes the progress of scientific investigation activities at Yucca Mountain, NV. For more details, see article on page 5.

Second Report to the U.S. Congress and the U.S. Secretary of Energy, November 1990.

This report by the Nuclear Waste Technical Review Board tracks progress on topics that were identified in the Board's first report (March 1990) and discusses issues central to determining the suitability of the proposed site for a geologic repository at Yucca Mountain, NV. Copies of the Second Report can be requested in writing from the Superintendent of Documents, U.S. Government Printing Office, Washington, DC 20402. (Stock number 061-000-00752-1: \$4.75) is 


\section{Iransportation Coordination Group Meets in Albuquerque, NM}

More than 112 people attended the Group Meeting on December 4 and 5, 1990, in Albuquerque, NM. Attendees included representatives from Federal, State, local, and Tribal governments, as well as their contractors, representatives from the transportation industry, interest groups, utilities, and education groups.

The meeting began with presentations by representatives of DOE, the State of Nevada, utilities, affected Nevada counties, and national and regional groups. In the afternoon, attendees broke into small groups for workshops devoted to discussions on the operations and institutional programs. These workshops continued the following morning. A panel discussion and wrap-up briefing for all attendees concluded the meeting in the afternoon. twelfth Transportation Coordination
The institutional session participants focused their discussion on the preliminary draft document, "Strategy to Provide Training Assistance as Required by Section 180 (c) of the Nuclear Waste Policy Act, as Amended," which was sent to them before the meeting. In this draft, OCRWM outlines its proposed five-step implementation strategy as follows:

1) Continue efforts with the interested groups to resolve assistance issues;

2) Develop a policy options paper identifying possible implementation processes;

3) Issue an assistance policy statement identifying the option selected;

4) Issue a plan detailing the implementation process; and

5) Initiate training assistance.
Panel discussions at the conclusion of the workshop sessions helped facilitate interaction among participants. One panel, with representatives from the DOE, the Federal Emergency Management Agency, the Western Interstate Energy Board, the ShoshoneBannock Indian Tribes, and the Commercial Vehicle Safety Alliance initiated discussion on issues presented in the Section 180(c) strategy. Audience feedback during these discussions focused on elements of potential training assistance.

The operations session discussion focused on the current activities in the following seven areas:

1) Transportation requirements and description;

2) Overview of current operations planning activities;

3) Potential impacts on the transportation system in implementing waste acceptance;

4) Cask maintenance - requirements and feasibility study;

In order to provide the public with current information, and to answer questions about DOE's Yucca Mountain studies to determine the possible suitability of the site for a geologic repository for nuclear waste, the DOE Yucca Mountain Site Characterization Project Office held Project Update Meetings in Hawthome, Amargosa Valley, and Henderson, NV, on November 7, 8, and 20, respectively.

The meetings in Amargosa and Henderson were well attended, while the meeting in Haw thorne attracted only a few interested citizens. During the Amargosa and Henderson meetings, Project Manager Carl P. Gertz gave a general overview of the current status of the Project. A representative from Clark County also gave a presentation during the Henderson meeting. This was followed by a question and answer session conducted by Gertz. The State of Nevada declined an invitation to participate in the meetings.

Following the question and answer sessions at the three meetings, audience members had the opportunity to join in informal "poster sessions." During these sessions, scientists gave brief presentations in their respective fields of expertise. This allowed more personalized discussion between Project staff and community members. Some of the topics discussed during the "poster sessions" were transportation, seismology, hydrology, Native American Indian cultural resources, and radiation. t)
5) Facility constraints;

6) Infrastructure studies; and

7) Site specific service planning and OCRWM observations of ongoing handling/shipping activities.

The opportunity for a predecisional forum to comment on the Section 180 (c) strategy and make recommendations prior to its being presented to the public was well received. DOE representatives encouraged the audience to submit written comments on the draft by January 31, 1991, for evaluation. To receive further information regarding this meeting, please contact Christopher Kouts at (202) 586-9761. 


\section{Selected Events Calendar}

Feb. 24-28

Waste Management '91, Holiday Inn Downtown, Tucson, AZ. Contact Roy Post, (602) 621-6158.

Apr. 28-May 2

'91 International High-Level Radioactive Waste Management Conference. Sponsored by DOE, ASCE, and ANS, Las Vegas, NV. Contact Robert Philpott, (202) 586-5396.

May 2-4

National Conference of State Legislatures State-Federal Assembly, Grand Hyatt, Washington, DC. Contact NCSL Meetings Office, (202) 624-5400.

June $2-6$

American Nuclear Society Annual Meeting, Marriott's Orlando World Center, Orlando, FL. Contact John DeMastry, (407) 694-3616.

\section{DOE/NRC INTERACTION MEETINGS}

Feb. 20

Seismic Hazards Investigation Staff Technical Position. (Location To Be Determined.)

Mar. 12

Procedural Agreement Meeting. (Location To Be Determined.)

Mar. 20-21

Radionuclide Retardation Testing Modeling. (Location To Be Determined.)

Apr. 16

Thermal Loads and Repository Design. (Location To Be Determined.)

For details on DOE/NRC meetings call (1/800) 368-2235 for a recorded message. In the Washington, DC, area call 479-0487.

A telephone recording service has been established for the announcement of upcoming meetings related to the waste management program of the NRC. The number is (1/800) 368-5642, ext. 20436. Washington, DC, area residents should call 492-0436.

For information on meetings and events occurring between issues of the OCRWM Bulletin use OCRWM INFOLINK, a computerized data base containing information about the OCRWM program. The OCRWM Bulletin is also available online through INFOLINK. 
United States Department of Energy Office of Civilian Radioactive Waste Management Washington, DC 20585

February/March 1991

\section{OCRWM Fiscal Year 1992 Budget Request}

The Department of Energy's (DOE) FY 1992 request for the Nuclear Waste Fund is $\$ 305.1$ million as compared to $\$ 242.8$ million for FY 1991 (see table below and accompanying budget allocation chart). The FY 1992 budget request for the

Civilian Radioactive Waste Research and Development program, as part of DOE's Energy Supply Research and Development programs is $\$ 0.7$ million. Highlight of OCRWM's request, including a budget table, a budget allocation chart, and a summary of the budget are provided.

\section{FY 1992 Congressional Budget Request, Nuclear Waste Fund (Dollars in Thousands)}

$$
\underset{\text { Appropriation }}{\text { FY } 1990} \text { FY } 1991
$$

FY 1992

Request

First Repository

$$
\text { Operating Expenses }
$$

Subtotal

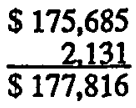

$$
\begin{array}{r}
\$ 154,180 \\
1,000 \\
\hline \$ 155,180
\end{array}
$$

$\begin{array}{r}\$ 170,241 \\ 2,000 \\ \hline \$ 172,241\end{array}$

Monitored Retrievable

Storage

Operating Expenses

Subtotal

$$
\begin{array}{r}
\$ 3,000 \\
\hline \$ 3,000
\end{array}
$$

$\$ 32,225$

$\frac{0}{\$ 32,225}$

\$ 8,797

$\frac{0}{\$ 8,797}$

\$ 27,483

$\frac{0}{\$ 27,483}$

$\$ 38,851$

$\frac{0}{\$ 38,851}$
$\$ 22,000$
$\$ 22,000$

$\$ 65,240$

$\frac{0}{\$ 65,240}$

$\$ 51,173$

200

$\$ 51,373$

$\$$

$\$ 242,833$

$\$ 241,633$

$\frac{1,200}{\$ 242,833}$ (continued on page 2)

\section{In This Issue...}

OCRWM Fiscal Year 1992 Budget Request

Page

DOE Publishes Preliminary Estimates of the Toual 3 System Cost for the Restructured Program

DOE Issues Comment Response Document for the 4 Secretary of Energy's "Report to Congress on

Reassessment of the Civilian Radioactive Waste

Management Program"

DOE Issues Annual Capacity Report

DOE Ready to Begin New Work at

Yucca Mountain, Nevada

NWTRB Reviews DOE Ouality

Assurance Procedures

DOE Issues Environmental Protection

Implementation Plan for the

Yucca Mountain Project

Second Annual Intemational High-Level Waste Maragement Conference To Be Held

OCRWM ro Hold Third

Strategic Principles Workshop

Yucca Mountain Engineered Barrier System Concepts Worteshop

NCAI Conducts Workshop on

Radioactive Waste Issues

Selected Events Calendar

New Publications and Documents

Index to all Issues of 1990 OCRWM Bulletins

NOTETOREADERS:The OCRWMBullesinis availableto users of INFOL DNK about one week before publication. To be placed on the meiling list, tomekexny address corrections, or to request multiple copies of the $O C R$ WHM Bulletin, pleaso contset Judy Hockenberry, MA-234-2, DOE, Germintown Building, Weshington, DC 20545, (301) 353-3118.

Publlshed by the U.S. Department of Energy (DOE), Office of Clvillan Radloactive Waste Management (OCRWM)

For further information about the national program or for coples of new OCRWM publications and documents listed in the OCRWM Bulletin contact the U.S. Department of Energy, OCRWM, Office of External Relations, Mail Stop RW-5.1, 1000 Independence Avenue, S.W., Washington, DC 20585, (202) 586-5722. The OCRWM information Services Directory ls available to provide sources of program information. 


\section{OCRWM Fiscal Year 1992 Budget Request \\ (continued from page 1)}

Highlights of activities to be undertaken during FY 1992 include:

First Repository (\$172.2 million)

- Continue data collection from existing monitoring stations and initiate new surface-based testing activities including Midway Valley and Trench 14 field activities $\$$ \$4.2 million);

- Complete exploratory shaft facility (ESF) design and initiate site preparation construction activities. Continue Title II design for ESF surface and sub-surface facilities. Begin planning for long lead-time procurements to support the commencement of ESF construction in FY93 (\$24.4 million);

- Ensure regulatory requirements are maintained. Continue interaction with the Nuclear Regulatory Commission (NRC), Nuclear Waste Technical Review Board, Advisory Committee on Nuclear Waste, Environmental Protection Agency, and the State of Nevada (\$20.2 million);

- Provide financial assistance to the State of Nevada (grants and payments-equal-to-taxes), grants to affected local governments, and grants directly to Nevada universities (\$13.0 million); and

- Intemationalactivities ( $\$ 8.0$ million).

\section{Monitored Retrievable Storage (MRS) (\$32.2 million)}

- Principal MRS activities include the initiation and completion of Title I design, initiation of Title II design, issuance of a final Environmental Assessment, initiation of the license application, MRS prototype demonstrations, and continued support to the Negotiator.

\section{OCRWM Program Proposed FY 1992 Request}

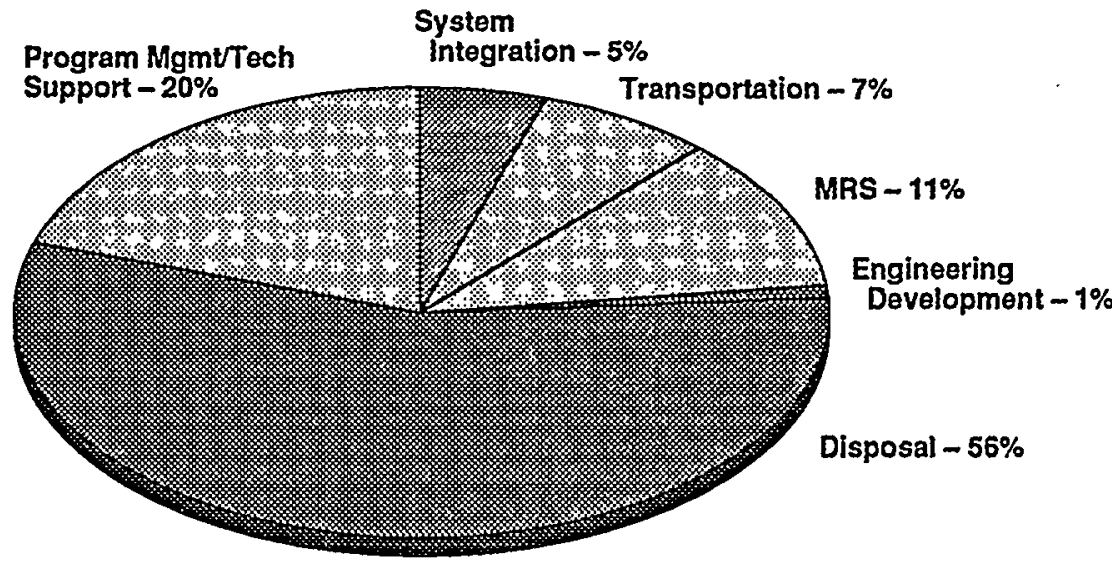

\section{Systems Integration (\$15.0 million)}

- Ensure integration of various system components into a single waste management system and

- Conduct special studies on programmatic needs and recommendations from program participants and oversight groups.

\section{Engineering Development (\$2.5 million)}

- Continue development and demonstration of new, cross-cutting technologies to support the operation of the waste management system and

Program ManagementandTechnical Support (\$61.8 Million)

- Provide for salaries, benefits, travel, and contractual services and supplies. Fund technical support services.
Transportation (\$21.4 million)

- Completeand submit Safety Analysis Report for Packaging to the NRC for certification of Legal-Weight Truck Cask and Rail/Barge Cask designs;

- Continue existing cooperative agreements with various national, regional and local groups. Add Northeastern Regional Group to the existing agreement;

- Support MRS planning activities by conducting MRS environmental assessment transportation analyses; and

- Continue the development of capabilities for operational testing and develop alternative testing scenarios. 


\section{DOE Publishes Preliminary Estimates of the Total-System Cost for the Restructured Program}

Each year a comprehensive analysis of the total cost of the radioactive waste management system over its complete lifecycle isperformedas anaid to financial planning for the OCRWM program. The primary use of the total-system life cycle cost (TSLCC) analysis is to provide cost data necessary for determining whether the fees paid by the waste generators will be sufficient to cover fully the costs of the program (see the fee adequacy analysis discussion in the December 1990/January 1991 issue of the OCRWM Bulletin).

In May 1989, DOE published its fifth Analysis of the Total-System Life Cycle Cost for the Civilian Radioactive Waste Management Program. Shortly after this analysis was completed, work was initiated to assess the overall program strategy. This activity culminated in November 1989, when the Secretary of Energy issued the Report to Congress on Reassessment of the Civilian Radioactive Waste Management Program (DOE's response to the comments on this report appear on page 4).

The current TSLCC study was prepared as an addendum to the May 1989 TSLCC report, and represents a preliminary assessment of the impact of the restructured program on the total-system costs. This study provided the basis for the sixth annual fee adequacy assessment. A more thorough evaluation of the cost impacts associated with the restructured program will be contained in the next complete TSLCC analysis.

\section{Analysis Results}

Total-system life cycle costs were estimated for three cases that are distinguished by thenumber of repositories and the quantity of spent fuel requiring disposal. The principal findings of this analysis follow:

- The total-system cost for a single repository system is estimated at
$\$ 25.6$ billion (in constant 1988 dollars) based on the no-new-orders, end-of-the-reactor-life spent-fuel projection.

- The total-system cost for a two repository system is estimated at $\$ 33.6$ billion for the no-new-orders, end-of-reactor-life spent-fuel projection, or $\$ 34.6$ billion for an upper reference case spent-fuel projection.

- The defense waste share of the totalsystem cost is estimated torange from $\$ 3.8$ billion (single repository system) to $\$ 5.8$ billion (two repository system).

\section{Changes from the May 1989 TSLCC Analysis}

The table below summarizes the cost impact by major cost component of the changes from the previous analysis:

(continued on page 6)

\section{Comparison of total-system costs to previous estimates (Millions of 1988 dollars)}

\begin{tabular}{|c|c|c|c|c|c|c|}
\hline \multirow[b]{2}{*}{ Cost category } & \multicolumn{3}{|c|}{$\begin{array}{l}\text { Single Repository } \\
\text { No-new-orders }\end{array}$} & \multicolumn{3}{|c|}{$\begin{array}{l}\text { Two Repository } \\
\text { No-new-orders }\end{array}$} \\
\hline & $\begin{array}{l}\text { May } 1989 \\
\text { TSLCC }\end{array}$ & $\begin{array}{c}1990 \\
\text { TSLC̣C }\end{array}$ & Change & $\begin{array}{l}\text { May } 1989 \\
\text { TSLCC }\end{array}$ & $\begin{array}{c}1990 \\
\text { TSLCC }\end{array}$ & Change \\
\hline $\begin{array}{l}\text { Development and } \\
\text { evaluation }\end{array}$ & 9,650 & 11,508 & $+1,858$ & 13,055 & 15,033 & $+1,978$ \\
\hline MRS facility & 1,809 & 1,862 & +53 & 1,387 & 1,613 & +226 \\
\hline Transportation & 2,614 & 2,803 & +189 & 2,325 & 2,658 & +333 \\
\hline First repository & 9,063 & 8,735 & -328 & 7,006 & 6,992 & -14 \\
\hline Second repository & $\mathrm{NA}^{\circ}$ & NA & NA & 6,582 & 6,551 & -31 \\
\hline Benefits payments & 701 & 657 & -44 & 856 & 793 & -63 \\
\hline Total-System Cost & 23,837 & 25,565 & $+1,728$ & 31,211 & 33,640 & $+2,429$ \\
\hline
\end{tabular}

Not applicable

(NOTE: Columns may not add to totals due to independent rounding.) 


\section{DOE Issues Comment Response Document for the Secrefary of Energy's "Report to Congress on Reassessment of the Civilian Radioactive Waste Management Program"}

On November 29, 1989, the Secretary of Energy published his Report to Congress on the Reassessment of the Civilian Radioactive Waste Management Program, and sent copies to numerous interested parties for their review and comment. Twenty-five letterscommenting on the Report were received. In these letters, 130 comments were identified that related to the following seven categories: management, institutional, regulatory, transportation, monitored retrievable storage, scheduling, and the repository.

DOE has issued a comment response document that provides a synopsis of the comments received, and DOE's current responses to those comments. DOE's views on these matters will be further reflected in the Draft Mission Plan Amendment, also to be issucd for public comment. The comment response

\section{DOE Issues Annual Capacity Report}

The Standard Contract for Disposal of Spent Nuclear Fuel and/or High-Level Radioactive Waste (10 Code of Federal Regulations 961) provides for the acquisition of title to spent nuclear fuel (SNF) and/or high-levelradioactive waste (HLW) by DOE, its transportation to DOE facilities, and its subsequent disposal. It also requires DOE to issue an Annual Capacity Report (ACR) for planning purposes to project DOE's annual SNF/ HLW receiving capacity and present the annual acceptance ranking of the Purchasers for 10 years following the projected commencement of DOE facility operations. Beginning in April 1991, the contract requires an annual Acceptance Priority Ranking Report.

This 1990 issue of the ACR utilizes two projected WMS waste acceptance schedules as the bases for allocation of acceptance capacity to the Purchasers for a 10-year period following the projected commencement of facility operations. The acceptance schedules were selected to be representative of upper and lower boundaries for a WMS which includes an MRS facility capable of receiving and storing SNF starting in 1998. Use of an MRS facility would require early MRS facility siting and modifications to the licensing conditions of the Nuclear Waste Policy Amendments Act.
During the first 10 years of projected WMS operation, the total quantity of spent fuel that could be accepted is projected to be: 24,100 Metric Tons Uranium (MTU) for the upper bounding case, as projected in the Draft 1988 Mission Plan Amendment; and7,375MTU for the lower bounding case. Acceptance priority ranking for the annual allocation of this WMS capacity is based on assigning the highestpriority, on an industry-wide basis, to the owners of the oldest SNF as determined by the date of Cinal discharge. The annual acceptance rates provide an approximation of the system throughput rates for the two selected waste acceptance schedules and are subject to change as program activities progress.

Section 1.0 of the ACR provides a discussion of the requirement for the ACR and the role it plays in DOE's interaction with the Purchasers in implementing the provisions of the Standard Disposal Contract. The two selected bounding cases for WMS waste acceptance schedules are presented in Section 2.0. Section 3.0 discusses the basis and procedure for allocating this capacity to each Purchaser, and summarizes the annualallocations for each selected receipt rate for the 10-year period covered by this report. A description of the ACR issue

(continued on page 7) document also includes as appendices: (1) a list of commenters; (2) a matrix that maps the comments highlighted in each letter to the appropriate section of the response summary that addresses that comment; (3) copiesof the commentletters with specific comments bracketed for response; and (4) copies of DOE response letters.

In general, the comments supported the Secretary's revised program strategy, including the reorganization of the Office of Civilian Radioactive Waste Management, the appointment of the OCRWMDirector, and a more aggressive management of the waste management program. Although many commenters stated their concern about the delay in the repository schedule, most agreed that the revised schedule was a more accurate indication of the amount of the work to be accomplished prior to waste acceptance at the repository. There were many comments supporting the emphasis on surface-based testing and the DOE's new approach to the scientific investigation of Yucca Mountain. Many commenters indicated that some linkages should be maintained between the repository and monitored retrievable storage (MRS) facility, and that the MRS facility should not become a de facto repository. Others noted that the schedule adjustments will actually reduce the time available for certain transportation-related activities, including route selection, mix of transport modes, and provision of emergency response training. There were also numerous comments on the role of affected parties in the DOE's management of the waste program.

For copies of the comment response document, contact the U.S. Department of Energy, OCRWM, Office of External Relations, Mail Stop RW-5.1, 1000 Independence Avenue, S.W., Washington, DC 20585, (202) 586-5722. 


\section{DOE Ready to Begin New Work at Yucca Mountain, Nevada}

Several sites in Midway Valley (east of Yucca Mountain) offer potential locations for repository surface facilities if Yucca Mountain is determined to be a suitable site. As part of site characterization, the geologic stability of Midway Valley must be determined.

DOE has completed the necessary study plans and readiness review, and received Nuclear Regulatory Commission (NRC) approval on the study plans. DOE is now ready to begin new site characterization work associated with Midway, Valley Trenching.

Study plans havealso been developed and approved to study the large vein-like deposits of calcite and silica that occur in faults near the site to determine the origin and age of the calcite and silica veins and infer possible future hydrologic conditions at the site.

However, before new site characterization activities could be undertaken it was necessary for OCRWM to verify through itsreadinessireview, and the $N$ RC toagree, that the Quality Assurance (QA) program was being effectively implemented. The NRC staff stated that the OCRWM QA program is acceptable for new site characterization activities limited to those associated with the Midway Valley Trenching and Calcite-Silica Activities, provided that certain recommended actions in a QA audit were completed and verified. A satisfactory resolution of the recommended action was completed, and the NRC was notified on January 31 , 1991.

Despite the actions described above, the State of Nevada, by refusing to issue necessary environmental permits, continues to impede OCRWM's Congressionally mandated responsibility to conduct scientific investigations to determine whether or not the Yucca Mountain site is suitable for a high-level radioactive waste repository.

\section{NWTRB Reviews DOE Quality Assurance Procedures}

Two panels of the Nuclear Waste Technical Review Board will hold a joint meeting on March 26, 1991, in Dallas, TX, to review the quality assurance (QA) program that DOE has implemented for the design and construction of an exploratory shaft facility at Yucca Mountain, NV. Pending resolution of a suit filed by the State of Nevada, the DOE intends to sink an exploratory shaft at the site at Yucca Mountain, which is being characterized by DOE as a possible location of a repository for permanent disposal of spent nuclear fuel and defense high-level waste. The meeting, which will be sponsored by the panels on Structural Geology and Gcoengineering and Quality Assurance, will run from 8:30 a.m. to 5:00 p.m. and will be held at the Adolphus Hotel, Sam Rayburn Room, 1321 Commerce, Dallas, TX 75202; (214) 742-8200.

(continued on page 8)

\section{DOE Issues Environmental Protection Implementation Plan for the Yucca Mountain Project}

The Yucca Mountain Site Characterization Project is committed to performing its activities in an environmentally safe and sound manner that complies with all applicable environmental statutes and regulations. To achieve that objective, an environmental program has been establishcd for the Yucca Mountain Site Characterization Project that includes the plansand activities necessary to satisfy applicable environmental regulatory and programmatic requircments as documented in a recently issued Environmental Protection Implementation Plan (EPIP) and in the Environmental Program Overview (see OCRWM Bulletin, Dccmber 1988).

It is important to note that the Project is not a DOE industrial, production, or operating type of facility. The Project is currently performing only the following activities: operation of a sample management facility; small scale, low impactgeological, ecological and archaeological studies; and ongoing meteorological, radiological, and air quality monitoring.

This EPIP addresses environmental protection only during site characterization of the Yucca Mountain site. The Project site characterization program is described in the Site Characterization Plan (see OCRWM Bulletin, December 1988). If Congress approves Yucca Mountain as the location for the high-level nuclear waste repository, a new EPIP will be prepared during site characterization to address environmental protection during construction, operation, and closure of the repository.

The EPIP applies to all Project activities, including management, administration, planning, design, construction, and operation. It also applies to all Project staff and the various Projectparticipants involved in performing parts of the environmental protection program.

Requests for copies and information regarding details of the EPIP should be addressed to Kathleen Grassmeicr, Chicf, Operations Control Branch, U.S. Department of Energy, Yucca Mountain Site Charactcrization Project Office, P.O. Box 98608, 101 Convention Center Drive, Las Vegas, NV 99193-8606, (702) 794-7525. 


\section{Second Annual International High-Level Radioactive Waste Management Conference to be Held}

The Second Annual International HighLevel Radioactive Waste Management Conference will be held on April 28 - May 2, 1991, at Caesar's Palace Hotel, Las Vegas, NV. The Conference will be an international forum featuring presentations and the discussion of scientific and technical information on management and disposal of high-level radioactive wastes. More information regarding topics to be addressed at the conference can be found on the program shown on page 7.

Papers presented at the Conference will be distributed there. Abstracts of these papers have been peer reviewed. Key speakers who are expected to address the Conference include John W. Bartlett (Director, OCRWM); Sten Bjurstrom (President, SvenskKarnbranslehantering); JamesR.Curtiss (Commissioner, Nuclear Regulatory Commission); Don U. Deere
(Chairman, Nuclear Waste Technical Review Board); Kunihiko Uematsu (Director General, Nuclear Energy Agency); and Michael M. Wilson (Commissioner, Florida Public Service Commission). The keynote speaker will be Margaret Maxey of the University of Texas, Austin.

The Conference is expected to provide an informative exchange of scientific and technical information. In addition, a variety of exhibits sponsored by leading contractors and businesses providing safety and security services and products dealing with high-level radioactive waste will be shown. For morc information on the Conference contact Robert Philpott, U.S. Department of Energy, Office of External Relations, 1000 Independence Avenue, S.W., Washington, DC 20585, (202) 586-5396.

Ł

\section{DOE Publishes Preliminary Estimates of the Total-System Cost for the Restructured Program (continued from page 3)}

The majority of the assumptions and methodologies remain the same in boith estimates. However, a major change in the schedule as a result of the restructured program had a significant impact on the updated estimates. The overall impact ranges from an increase of approximately $\$ 1.7$ billion for the single-repository case to approximatcly $\$ 2.4$ billion for the two-repository case.

For both cases, the majority of the cost impact of the restructured program is due to an increase of approximately $\$ 2.0$ billion in the development and evaluation cost (D\&E) component. This component covers all siting, preliminary design devclopment, testing, regulatory compliance, and institutional activities for the program. It also includes the costs of administration by the Federal government and the fees charged by the Nuclear Regulatory Commission for licensing. The increase in D\&E cost is due to additional costs from the delay in the start of repository operations.

For copies of the Preliminary Estimates of the Total-System Cost for the Restructured Program: An Addendum to the May 1989 Analysis of the Total-System Life Cycle Cost for the Civilian Radioactive Waste Management Program, contact the U.S. Department of Energy, OCRWM, Office of External Relations, Mail StopRW-5.1, 1000) Independence Avenue, S.W., Washington, DC 20585, (202) 586-5722.

\section{OCRWM to Hold Third Strategic Principles Workshop}

On April 3-4, 1991, in Denver, CO, OCRWM will hold the third in a series of workshops on waste management policies and strategic principles. In the first workshop, held in Salt Lake City, UT, the discussion focused primarily on strategic principlesrelated to ensuring public safety and protecting the environment. The second workshop, held in Washington, $D C$, dealt with thestewardship of resources and effectiveness of operations. Because of the very productive dialogue in the first two workshops, a third workshop has been scheduled to focus on the approach that OCRWMplans totakeregarding the issues discussed at the earlier workshops. The results of these workshops will be considered in preparing an amended Mission Plan to be issued later this year.

The meetings will beopen to the public, as they were during the previous workshops. In order to ensure full and free discussion, they will be moderated by a professional and neutral facilitator experienced in guiding such public discussions. Participants will be asked to speak as individuals rather than as official representatives of their organizations. Notes will be taken, but individual participants will not be quoted in written products prepared on the basis of conference discussions. This approach is being taken in order to encourage parties to express their diverse views at the workshops.

Dr.JohnW.Bartlett, Director of OCRWM, will be attending the conference. For further information, contact Richard Blaney, U.S. Department of Energy, OCRWM, 1000 Independence Avenue, SW, Mail Stop RW-42, Washington, DC 20585, (202) 586-1252. 


\section{PROGRAM}

\section{International High-Level Radioactive Waste Management Conference April 28 - May 2, 1991 - Caesars Palace Hotel - Las Vegas, Nevada}

\begin{tabular}{|c|c|c|c|c|c|}
\hline \multirow{2}{*}{$\begin{array}{l}\text { Monday, Aprll } 29 \\
\text { 1:30 pm-2:30 pm. } \\
\text { Natural Systems } \\
\text { Plenary }\end{array}$} & \multicolumn{2}{|c|}{ Tuesday, Aprll 30} & \multicolumn{2}{|c|}{ Wednesday, May 1} & \multirow{2}{*}{$\begin{array}{l}\text { Thursday, May } 2 \\
\text { 11:00 a.m. 12:30 pm. } \\
\text { Rapporteur Session }\end{array}$} \\
\hline & $\begin{array}{c}\text { 8:30 am.-0:30 a.m. } \\
\text { Engineered Systems } \\
\text { Plenary }\end{array}$ & $\begin{array}{l}\text { 1:45 pm.-2:45 p.m. } \\
\text { Integrated Systems } \\
\text { Plenary }\end{array}$ & $\begin{array}{l}8: 30=\mathrm{m} .9: 30=\mathrm{m} . \\
\text { Social Systems } \\
\text { Plenary }\end{array}$ & - & \\
\hline $\begin{array}{l}\text { 2:45 p.m.5:00 p.m. } \\
\text { Current issues in U.S. } \\
\text { and Internatlonal HLW } \\
\text { Regulations }\end{array}$ & $\begin{array}{c}\text { 9:45 am.-12 noon } \\
\text { Aspects of Repository } \\
\text { Performance Under EPA } \\
\text { Regulations }\end{array}$ & $\begin{array}{l}\text { 3:00 p.m.-5:15 p.m. } \\
\text { Utility Regulatory } \\
\text { Experionce Appliod to } \\
\text { the High-Lovel Wasto } \\
\text { Repository Program }\end{array}$ & $\begin{array}{l}\text { 9:45 am.-12 noon } \\
\text { Regutatory Aspects of } \\
\text { Site Characterization }\end{array}$ & $\begin{array}{l}\text { 1:45 pm.-5:00 pm. } \\
\text { Implementalion of } \\
\text { Selocted Regulatory } \\
\text { Processes }\end{array}$ & \\
\hline $\begin{array}{l}\text { 2:45 pm.5:00 pm. } \\
\text { Transport Cask Systems } \\
\text { Deslgn and Technology }\end{array}$ & $\begin{array}{l}\text { 9:45 am,-12 noon } \\
\text { Underground Facility } \\
\text { Design }\end{array}$ & $\begin{array}{l}\text { 3:00 p.m-5:15 p.m. } \\
\text { Transportation } \\
\text { Systems-1 }\end{array}$ & $\begin{array}{c}9: 45 \text { a.m.-12 noon } \\
\text { Waste-Package } \\
\text { Materials }\end{array}$ & $\begin{array}{l}\text { 1:45 p.m.-5:00 p.m. } \\
\text { Transport Cask Testing } \\
\text { and Analyses }\end{array}$ & $\begin{array}{l}\text { 8:30 a.m. }-10: 45 \text { am. } \\
\text { Transportation } \\
\text { Systems-ll }\end{array}$ \\
\hline $\begin{array}{l}\text { 2:45 pm.-5:00 pm. } \\
\text { Solsmotectonles and } \\
\text { Volcanology }\end{array}$ & $\begin{array}{l}\text { 9:45 am-12noon } \\
\text { Al-Reactor Storage }\end{array}$ & $\begin{array}{l}\text { 3:00 pm.-5:15 pm. } \\
\text { Monitored Retrlovable } \\
\text { Storage }\end{array}$ & $\begin{array}{l}9: 45 \text { am.-12 noon } \\
\text { Unsaturated Zone } \\
\text { Hydrologic Testing }\end{array}$ & $\begin{array}{l}\text { 1:45 p.m.-5:00 pm. } \\
\text { Saturated Zone } \\
\text { Hydrology }\end{array}$ & \\
\hline $\begin{array}{l}\text { 2:45 p.m.-5:00 pm. } \\
\text { Spent Fuel } \\
\text { Characterlstles }\end{array}$ & $\begin{array}{l}9: 45 \text { a.m.-12 noon } \\
\text { Vitrifled Waste } \\
\text { Processing }\end{array}$ & $\begin{array}{l}\text { 3:00 pam.-5:15 pm. } \\
\text { Vitrifiod Waste Forms } \\
\text { Characteristics }\end{array}$ & $\begin{array}{l}\text { 9:45 a m.-12 noon } \\
\text { Intergovernmental issues }\end{array}$ & $\begin{array}{l}\text { 1:45 p.m.-5:00 p.m. } \\
\text { Institutional Approaches to } \\
\text { Fesolving Technical lssues }\end{array}$ & $\begin{array}{l}\text { 8:30 am.-10:45 am. } \\
\text { Soclooconomic Impact } \\
\text { Assessment }\end{array}$ \\
\hline $\begin{array}{l}\text { 2:45 p.m.5:00 pm. } \\
\text { Sclonce Education and } \\
\text { Publlc Awareness }\end{array}$ & $\begin{array}{l}\text { 9:45 a.m.-12 noon } \\
\text { Internatlonal Panol on } \\
\text { Publlc Education About } \\
\text { High-Lovel Waste }\end{array}$ & $\begin{array}{l}\text { 3:00 p.m-5:15 p.m. } \\
\text { Risk Perception and } \\
\text { Public Involvement }\end{array}$ & $\begin{array}{l}9: 45 \text { a.m.-12 noon } \\
\text { Radionuclide Release } \\
\text { from the Engineered } \\
\text { Barier System }\end{array}$ & $\begin{array}{l}\text { 1:45 p.m.-5:00 pm. } \\
\text { Near-Frold Procosses } \\
\text { Aflecting the Engineered } \\
\text { Systems }\end{array}$ & $\begin{array}{l}\text { 8:30 a.m.-10:45 a.m. } \\
\text { Thermal Considerations } \\
\text { In Undarground Design }\end{array}$ \\
\hline $\begin{array}{l}\text { 2:45 p.m.5:00 p.m! } \\
\text { Transport Processes }\end{array}$ & $\begin{array}{l}9: 45 \text { am.-12 noon } \\
\text { Geochomistry-1 }\end{array}$ & $\begin{array}{l}\text { 3:00 p.m.-5:15 pm. } \\
\text { Geotechnical Exploration }\end{array}$ & $\begin{array}{l}\text { 9:45 a.m.-12 noon } \\
\text { Assessment and } \\
\text { Evaluation of } \\
\text { Underground Excavation } \\
\text { Techniques }\end{array}$ & $\begin{array}{l}\text { 1:45 p.m.-5:00 p.m. } \\
\text { Geochemistry-ll }\end{array}$ & $\begin{array}{l}\text { 8:30 a.m.-10:45 a.m. } \\
\text { Underground Mechanical } \\
\text { Excavation Techniques } \\
\text { and Technology }\end{array}$ \\
\hline $\begin{array}{l}\text { 2:45 pm.5:00 p.m. } \\
\text { Design Control } \\
\text { Methodology }\end{array}$ & $\begin{array}{l}\text { 9:45 a.m-12 noon } \\
\text { Unsaturated Zone } \\
\text { Hydrology-1 }\end{array}$ & $\begin{array}{l}\text { 3:00 p.m.5:15 p.m. } \\
\text { Unsaturated Zone } \\
\text { Hydrology-II }\end{array}$ & $\begin{array}{l}\text { 9:45 a.m.-12 noon } \\
\text { Waste Management } \\
\text { System Development }\end{array}$ & $\begin{array}{l}\text { 1:45 p.m.-5:00 pm. } \\
\text { Environmemal Resource } \\
\text { Assessments and Modeling }\end{array}$ & $\begin{array}{l}\text { 8:30 am.-10:45 am. } \\
\text { Intertm Storage }\end{array}$ \\
\hline $\begin{array}{l}\text { 2:45 p.m.5:00 pm. } \\
\text { Goomechanics : }\end{array}$ & $\begin{array}{l}\text { 9:45 am.-12 noon } \\
\text { in-Sxu and Laboratory } \\
\text { Testing }\end{array}$ & $\begin{array}{l}\text { 3:00 p.m.5:15 p.m. } \\
\text { Performance Assessment } \\
\text { Scientific Basis and } \\
\text { Regulatory Noeds }\end{array}$ & $\begin{array}{l}9: 45 \text { a.m.-12 noon } \\
\text { Performance Assessment } \\
\text { Case Studies }\end{array}$ & $\begin{array}{l}\text { 1:45 p.m.5:00 pm. } \\
\text { Performance Assessment } \\
\text { Scenarios and } \\
\text { Uncertaintles }\end{array}$ & $\begin{array}{l}\text { 8:30 a.m.-10:45 am. } \\
\text { Performance Assossment } \\
\text { System Analysis }\end{array}$ \\
\hline
\end{tabular}

\section{DOE Issues Annual Capacity Report (continued from page 4) .}

resolution process and a report on its current status are contained in Section 4.0 along with DOE's responses to Purchaser comments on previous ACRs. Annual acceptance capacity allocated to each Purchaser, based on the chronological listing of spent fuel assembly final discharge dates and the two selected WMS acceptance rates is summarized in
Appendix A. Appendix B is a detailed listing of the eligible SNF, by date of final discharge, covered by the Standard Disposal Contract. These data will be the basis for the Acceptance Priority Ranking report.

Comments on this ACR should be addressed to Mr. Alan Brownstein,
Department of Energy, OCRWM, RW-43, 1000 Independence Avenue, S.W., Washington, DC 20585. For copies of the Annual Capacity Report, contact the U.S. Department of Energy, OCRWM, Office of External Relations, Mail Stop RW-5.1, 1000 Independence Avenue, S.W., Washington, DC 20585, (202) $586-5722$. 


\section{Yucca Mountain Engineered Barrier System Concepts Workshop}

DOE is seeking participants who may be interested in presentingEngineered Barrier System (EBS) concepts at a workshop to be held June 18-20, 1991, in Denver, CO.

The objectives of the workshop are to: (1) provide a forum for the discussion of engineered barrier system concepts and their applicability to extended life performance, and (2) solicit the opinions of experts regarding extended life engineered barrier system concepts at the potential high-level radioactive waste repository at Yucca Mountain, NV. The EBS is defined as the waste packages and the underground facility including openings and backfill materials, but excluding shafts, boreholes, and their seals. Extended life refers to exceeding the regulatory performancestandardsimposed on the EBS and its components.

Participants for the workshop will be selected based on their personal qualificationsand their technical submittal of the proposed concept. Interested parties should submit a qualification statement that includes a one-page discussion on why the individual believes he or she is qualified to address the subject. DOE will then ask those who havequalified to submit a technical analysis. This analysis should include a description of the concept, physical and/or chemical processes relied on forcontainmentand isolation, predicted performance, degree of insensitivity to variations in service environment, fabrication andemplacementaspects, and rough cost estimates.

DOE will send an information package about requirements imposed on design when requests for technical analyses of the qualifying parties are issued. This invitation for participation in the workshop should not be construed as a request for a proposal for future work in this area or as acommitment to compensate participants in any manner.
Individuals interested in participating in the workshop should submit their qualifications by March 15, 1991, for consideration by DOE. Requested technical submittals will be due to DOE by April 19, 1991. Send qualification

statement to Diane J. Harrison-Geisler, U.S. Department of Energy, Yucca Mountain Site Characterization Project Office, M/S 523, P.O. Box 98608, Las Vegas, NV 89193-8608.

\section{NCAI Conducts Workshop on Radioactive Waste Issues}

As part of an ongoing cooperative agreement between the National Congress of American Indians (NCAI) and DOE, the NCAI conducted a workshop on January 1516,1991 , in Sacramento, CA. The purpose of the workshop was to provide a forum where the DOE and tribal officials could present information and their respective views regarding the DOE's radioactive waste programs and the possible impact of these programs on Indian Tribes.

The workshop consistcd of presentations by NCAI, DOE and NRC officials, question and answer sessions, and a film. The NCAI presentations focused on Tribal plans, needs, and priorities for Tribal radioactive waste programs, as well as current Tribal activities in these programs. Other presentations discussed the spiritual and cultural bases of Tribal concerns about radioactive waste issues.

DOE presented an overview of the U.S. high-level waste programs as well as more specific topics such as the Yucca Mountain investigations, environmental restoration activities, transportation plans, and the Waste Isolation Pilot Plant with emphasis on Tribal interests. Other presentations included a discussion of the NRC's role in highlevel nuclear waste, and other DOE programs of special interest to Indian Tribes.

\section{NWTRB Reviews DOE Quality Assurance Procedures (continued from page 5)}

The next day, March 27, 1991, the Quality Assurance Panel will hold a meeting from 10:30 a.m. to 4:00 p.m. in the same room to review several aspects of the DOE's overall QAprogram fordesigning and constructingapermanentrepository. DOE representatives will update panel members on recent progress in remedying a number of QA implementation problems and brief members on an important component in the QA process called "grading," which refers to the process of determining whether and how an activity should be subjected to the $Q A$ process.

The members of the Quality Assurance Panel also are hoping to be briefed by a member of a new QA technical advisory committee, which is being created to address QA problems raised by researchers in the DOE's site-characterization program.

The public is welcome to attend the meeting as observers. Transcripts of the meeting will be available on a library-loan basis beginning April 22, 1991, from Ms. Victoria Reich, Board librarian. 


\section{Selected Events Calendar - 1991}

March 26

March 27

March 30-April 4

April 3-4

April 15-19

April 23-25

April 28-May 2

May 2-4
Nuclear Waste Technical Review Board, Joint Panel Meeting in Dallas, TX, of Quality Assurance Panel and Structural Geology and Geoengineering Panel on Quality Assurance of Exploratory Shaft Facility Preliminary Design. Contact Paula Alford, (703) 235-4473.

Nuclear Waste Technical Review Board, Quality Assurance Panel on DOE Quality Assurance Program, Dallas, TX. Contact Paula Alford, (703) 235-4473.

Commercial Vehicle Safety Alliance Spring Conference, Colorado Springs, CO. Contact Russ Fiste, (202) $775-8658$.

OCRWM Workshop on Waste Management Policies and Strategic Principles, Denver, CO. Contact Richard Blaney, (202) 586-1252.

Nuclear Waste Technical Review Board, Second Annual Full Board Meeting, Reno, NV. Contact Paula Alford, (703) 235-4473.

Nuclear Regulatory Commission Committee on Nuclear Waste, Bethesda, MD. ContactBarbara Jo White; (301) 492-7288.

2nd Annual International High-Level Radioactive Waste Management Conference sponsored by DOE, American Society of Civil Engineers, and American Nuclear Society, Las Vegas, NV. Contact Robert Philpott, (202) 586-5396.

National Conference of State Legislatures State-Federal Assembly, Grand Hyatt, Washington, DC. Contact NCSL Meetings Office, (202) 624-5400.

\section{New Publications and Documents}

Annual Capacity Report, DOE/RW-0294P, December 1990.

This report describes two selected bounding cases for waste management system waste acceptance schedules and discusses the basis and procedure for allocating capacity to each Purchaser. For more details, see article on page 4.

Preliminary Estimates of the Total-System Cost for the Restructured Program: An Addendum to the May 1989 Analysis of the TotalSystem Life Cycle Cost for the Civilian Radioactive Waste Management Program, DOE/RW-0295P, December 1990.

This report contains updates of estimates contained in the May 1989 Total-System Life Cycle Cost analysis that are affected by the restructured program strategy. For more details, see article on page 3.

Comment Response Document for the Secretary of Energy's Report to Congress on Reassessment of the Civilian Radioactive Waste Management Program, DOE/RW-0298P, November 1990.

This report summarizes comments received on the Secretary's Rcport and presents the DOE's current responses to those comments. Included as appendices are a list of commenters, a crosswalk showing where each comment is addressed, the comment letters themselves with specific comments delineated, and the DOE's responses to those letters. For more details, see article on page 4.

Environmental Protection Implementation Plan for the Yucca Mountain Site Characterization Project, November 1990.

This document describes the Yucca Mountain Site Characterization Project Environmental Implementation Protection Plan including environmental protection program plans and monitoring programs. For more details, see article on page 5. 

Accident dose criteria, Jn:3

effect during licensing phase, $\mathrm{Jn}: 3$

request for rulemaking, Jn:2-3

Advisory Council on Historic Preservation, F/Mr:11

\section{American Indian Tribes}

and cooperative agreement with OCRWM, S:4

development of news reports, $\mathrm{S}: 4$

feasibility grants, $\mathrm{O} / \mathrm{N}: 1$

National Congress of American Indians, S:4

and potential negotiated MRS site, $S: 4$

and potential negotiated repository site, $S: 4$

review of cultural resources studies, F/Mr:11, 13

technical assistance

information needs, $S: 4$

public safety, Jn:2

Apache Leap, Arizona, Jn:4 and Forest Service land, Jn:5

prototype drill site, photo $\mathrm{In}: 4$

Babcock \& Wilcox, Ja:3

Battelle Memorial Institute, F/Mr:4

Bechtel Systems Management, Inc. (BSMI), Jl/Ag:5

Brookhaven National Laboratory, F/Mr:4

Index Note. Page citations list teferences by date of isstie and page number. The page is cited after the colon. Seven issues were published in 1990 .

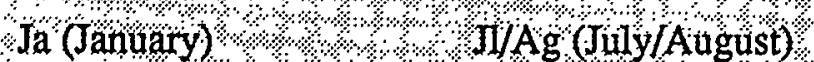

F/Mr (February/March) $\mathrm{S}$ (September)

Ap/My (April/May) ) O/N (October)

Jn? (June)

November)
Bureau of Land Management, O/N:4

Casks (see Transportation)

Churchill County, Nevada, Ap/My:2

Civilian Radioactive Waste Management Program concerns with management, F/Mr:1 review by Secretary of Energy, F/Mr:1

Clark County, Nevada, F/Mr:8

Code of Federal Regulations

10 CFR 60, Jn:2-3

40 CFR 191, F/Mr:10; J/Ag:3

Commission of European Communities, J/Ag:3

Conferences

Conference of Radiation Control Program Directors (CRCPD), Jn:2; J/Ag:5

International High-Level Radioactive Waste

Management Conference, Ap/My: 1

National Conference of State Legislatures, S:4-5

31st Annual Meeting of the Institute of Nuclear Materials Management (INMM), J//Ag:4

Consultation and cooperation, $\mathrm{J} / \mathrm{Ag}: 3$

Controlled zones, figure In:3

accident control zone (proposed), Jn:3

routine access zone (proposed), $\mathrm{Jn}: 3$

Cooperative agreements, J//Ag:5; S:4

with Conference of Radiation Control Program Directors, Jl/Ag:5

with National Conference of State Legislatures, S:4

with National Congress of American Indians, S:4 
Department of Justice, on Nevada and environmental permits, $\mathrm{O} / \mathrm{N}: 4$

Document integration, Jn:1

Education (see Science education)

Educational fellowships, S:5

Emergency preparedness, Jn:2

Environmental permits impasse on approval, F/Mr: 10

refusal to grant and effect on schedule for site investigation, Jn: 1

Environmental Protection Agency, J1/Ag:3 performance limits for radionuclide release from repository, J/Ag:4

and standards, F/Mr: 10

suggested review by, Jl/Ag:3

Environmental recommendations for Yucca Mountain studies, F/Mr:10

Environmental restoration, F/Mr: 1

Environmental studies, desert tortóise, F/Mr:8

Exploratory Shaft Facility, F/Mr:2, 6-7

Federal Register Notice, S:5

Federal Waste Management System, S:1

Fenix and Scission, $\mathrm{O} / \mathrm{N}: 5$

Forest Service, Jn:5

Funding

accountability as guiding principle, $\mathrm{S}: 1$

budget request, F/Mr:6-7, figure F/Mr: 6

costs of nuclear-generated energy, Ap/My:4

credits for past Nuclear Waste Fund overpayments, $S: 5$

economic incentives for potential host State or Indian Tribe, S:4-5

feasibility grants, $\mathrm{O} / \mathrm{N}: 1$

and grants to States, Indian Tribes, or units of local Lincoln County, Nevada, F/Mr:8

National Congress of American Indians fund for technical assistance, $\mathrm{S}: 4$

Nuclear Waste Fund, $S: 3,5$

fee calculation, $S: 3,5$

status of, F/Mr:7

summary, figure F/Mr:7

payments-equal-to-taxes (PETT), F/Mr:3

General Atomics, Ja:3

Highway route selection, Jn:2

Holmes \& Narver, O/N:5

Hydrogeology, recommendations at Yucca Mountain site, F/Mr:5, 9

Idaho National Engineering Laboratory (INEL), F/Mr:4

Indian Tribes (see American Indian Tribes)

INFOLINK II, S:6

Interim storage, $\mathrm{Ap} / \mathrm{My}: 4$

International Atomic Energy Agency (IAEA), $\mathrm{Jl} / \mathrm{Ag}: 3$

International cooperation, $\mathrm{Jl} / \mathrm{Ag}: 3$

International Lead Zinc Research Organization, F/Mr:4

Lawrence Livermore National Laboratory (LLNL), F/Mr:4; O/N:5

Lawsuits (see Litigation)

Legislation (see Nuclear Waste Policy Act, as amended, and Public Laws)

Licensing dose requirements, Jl/Ag:3

Nuclear Regulatory Commission requirements, Jl/Ag:3

process, Ja:2

government, $\mathrm{F} / \mathrm{Mr}: 7$ 


\section{Litigation \\ appeal by State of Nevada intended on Ninth \\ Circuit Court's decision, O/N:4 \\ and award of systems engineering, development, and management contract, J/Ag:5 \\ countersuit by DOE on disapproval of Yucca \\ Mountain site, Ja:1-2 \\ by Department of Justice to permit scientific investigations, $\mathrm{F} / \mathrm{Mr}: 2-3 ; \mathrm{O} / \mathrm{N}: 4$ \\ and environmental permits, Ja: 1 \\ by Nevada, F/Mr:2-3 \\ ruling in suit brought by State of Nevada, O/N:4 \\ and scientific studies of Yucca Mountain, Ja:1-2 \\ and Systems Engineering, Development, and \\ Management Contract, J1/Ag:5}

\section{Management Systems Improvement Strategy, \\ $\mathrm{S}: 1-2 ; \mathrm{O} / \mathrm{N}: 1 ;$ figure $\mathrm{S}: 3$}

initiatives and tasks, $S: 1-2$

management control systems, $\mathrm{O} / \mathrm{N}: 1$

Management Systems Improvement Plan, Jn:1, 6

Mission Plan Amendment, O/N:4

discussion draft of policies and strategic

principles, $\mathrm{O} / \mathrm{N}: 4$

workshops on key issues, $\mathrm{O} / \mathrm{N}: 4$

Monitored Retrievable Storage (MRS) facility, Ja:3; F/Mr:7; Ap/My:4; Jn:2, 6 economic incentives to host State or American Indian Tribe, $S: 5$

key activities, figure $\mathrm{O} / \mathrm{N}: 2$

linkages with repository schedule, F/Mr:2, 3

potential negotiated site, S:5

potential value of, F/Mr:5

schedule, F/Mr:2

shared oversight responsibilities at negotiated site, $\mathrm{S}: 5$

site selection, F/Mr:2

strategy to ensure spent fuel acceptance, S:1

summary of DOE position, $S: 1$

support for, $\mathrm{O} / \mathrm{N}: 1$

National Academy of Engineering, Jl/Ag:3

National Academy of Sciences, JV/Ag:3; O/N:1-2

National Conference of State Legislatures

(NCSL), S:4, 5
National Congress of American Indians (NCAI), $\mathrm{S}: 4$

National Energy Strategy, Ap/My:2, 4

National Research Council, Jl/Ag:3

Board on Radioactive Waste Management, $\mathrm{Jl} / \mathrm{Ag}: 3 ; \mathrm{O} / \mathrm{N}: 3$

recommendations, J//Ag:3, 6

National Science Foundation, Jl/Ag:3

Native American Tribes (see American Indian Tribes)

Nevada State Historic Preservation Office (NSHPO), F/Mr:11

Nominations

Office of Civilian Radioactive Waste Management Bartlett, J.W., Director, Ja:1; F/Mr:2

Office of the Nuclear Waste Negotiator Leroy, D.H., Negotiator, Jn:1

Nuclear Energy Agency of the Organization for Economic Cooperation and Development

(OECD/NEA), JV/Ag:3; O/N:3

Nuclear Regulatory Commission (NRC), Ja:2;

F/Mr:2, 10; Jn:1, 3; Jl/Ag:3

and cask certification, $\mathrm{Jn}: 2$

requirements for quality assurance program, $\mathrm{O} / \mathrm{N}: 5$

Nuclear Waste Fund (see Funding)

Nuclear Waste Negotiator (see Office of the Nuclear Waste Negotiator)

Nuclear Waste Policy Act, as amended, Ja:1, 2; F/Mr:10, 11; Ap/My:1; Jn:2; S:3, 4 and attempted veto of site characterization activities, $\mathrm{O} / \mathrm{N}: 4$

initiatives to meet requirements of, F/Mr:1 required payments, $\mathrm{F} / \mathrm{Mr}: 3$ 


\section{Nuclear Waste Technical Review Board \\ (NWTRB, also referred to as TRB), \\ F/Mr:2; Jl/Ag:4}

DOE to brief on spent fuel studies, Jl/Ag:5

Engineered Barrier System Panel, JV/Ag:4-5

and independent review, $\mathrm{O} / \mathrm{N}: 1-2$

interaction with $\mathrm{DOE}, \mathrm{F} / \mathrm{Mr}: 10$

issuance of first report, $\mathrm{F} / \mathrm{Mr}: 5$

panels, Jn: 6

public comment invited, J//Ag:4

relocation, J1/Ag:5

technical and scientific recommendations,

$\mathrm{F} / \mathrm{Mr}: 5,9,10$

Transportation Panel meeting, J/Ag:4

Nye County, Nevada, Ap/My:2

Office of Civilian Radioactive Waste

Management (OCRWM), J/Ag:1-2, chart

Jl/Ag:2

action plan, $\mathrm{O} / \mathrm{N}: 4$

appointments, Ap/My:1; J1/Ag:1-2, figure

J/Ag:2

direct-line reporting with Yucca Mountain

Project Office, F/Mr:3 .

facility siting, Ap/My:1

independent review of management, F/Mr:3

management approach, $\mathrm{Ap} / \mathrm{My}: 3$

management review, Jn: 1

1989 Publications, figure Ja:5

program planning, Ap/My:1, 3; Jn:2

reorganization of, J/Ag: $1-2,4 ; \mathrm{O} / \mathrm{N}: 3$

Office of the Nuclear Waste Negotiator, F/Mr:2;

$\mathrm{Jn}: 1 ; \mathrm{S}: 4 ; \mathrm{O} / \mathrm{N}: 1$

authorization to offer incentives, $S: 4-5$

international precedent for negotiated waste sites, S:5

nomination of Negotiator, Jn:1

timely siting, Ap/My:1

\section{Office of Quality Assurance, O/N:5}

\section{Organization for Economic Cooperation and}

Development (see Nuclear Energy Agency)

\section{Oversight}

cultural study review by American Indian Tribes,

$\mathrm{F} / \mathrm{Mr}: 11,13$

independent review, F/Mr:4; Jl/Ag:3; O/N:1-2 international scientific review recommended for

DOE plans, Jl/Ag:3

review of transportation program, $\mathrm{O} / \mathrm{N}: 5$

shared responsibilities at a negotiated facility,

S:5

Pacific Northwest Laboratories (PNL), F/Mr:4

Packaging alternatives, J//Ag:5

Performance assessment, J1/Ag:3, 4; O/N:1

Professional society participation, Jl/Ag:4

Program planning, Jn:1; Jl/Ag:3; S:1

contingency planning, Jl/Ag:3-4

reorganization, J/Ag:1

transportation, $\mathrm{Jn}: 2$

workshops with external parties, O/N:1

Prototype testing, Jn:4

development of methods, Jn:4

dry drilling and coring, $\mathrm{Jn}: 4$

dry drilling techniques, $\mathrm{F} / \mathrm{Mr}: 10$

dual wall drilling/coring system, figure $\mathrm{Jn}: 5$

dust collection and sampling, photo Jn:4

steps for dry drilling, Jn:4-5

Public communication, O/N:3

Public health, safety, and environment, F/Mr:4

Public laws

National Historic Preservation Act (NHPA), $\mathrm{F} / \mathrm{Mr}: 11$

release of Bureau of Land Management land, $\mathrm{O} / \mathrm{N}: 4$

Public participation, F/Mr:4; O/N:4-5

and historic preservation at Yucca Mountain, F/Mr:11, 13

and National Energy Strategy, Ap/My:2

and Nuclear Waste Technical Review Board's

Transportation Panel, Jl/Ag:4

and public confidence, F/Mr:4; Ap/My:2

perceptions of risks, Ap/My:2

in repository program, J/Ag:3

through cooperative agreements, $\mathrm{S}: 4$

and Yucca Mountain Information Office, Ja:2 
Quality assurance, F/Mr:7; S:1

current NRC acceptance of laboratory and contractor programs, $\mathrm{O} / \mathrm{N}: 5$

as guiding principle, $S: 1$

implementation of controls, Jn:1; O/N:5

monthly briefings with NRC, F/Mr:10

and oversight, $\mathrm{O} / \mathrm{N}: 5$

postponement of audits, Jn: 1,6

Quality Assurance Qualification Audits, $\mathrm{Jn}: 1, \mathrm{O} / \mathrm{N}: 5$

required certification of all $\mathrm{DOE}$ and $\mathrm{DOE}$ contractor personnel, $\mathrm{O} / \mathrm{N}: 5$

\section{Radiation safety}

radionuclide adsorption workshop, F/Mr:9

safety, Jn:3

\section{RADTRAN (computer code), F/Mr:9}

Regulations for geologic repositories, Jl/Ag:3

Reorganization, OCRWM (see Office of Civilian Radioactive Waste Management)

\section{Reports}

Annual Capacity Report for 1989, Jn:6

Annual Report for the Programmatic Agreement on Historic Preservation, F/Mr:11

Directory of State Agencies Concerned with the Transportation of Radioactive Material, $\mathrm{Jl} / \mathrm{Ag}: 5$

Draft floodplain/wetlands assessment, Ja:3

Environmental Field Activity Plan for Soils, Ap/My:5

Environmental Monitoring and Mitigation Plan, F/Mr:11

Environmental Program Overview, Ap/My:5

interim report on National Energy Strategy, Ap/My:2

legal developments reports (Transportation Legislative Data Base), Ap/My:5

Management Systems Improvement Strategy, S:1-2

Mission Plan Amendment (in development), $\mathrm{O} / \mathrm{N}: 4$

Notice of Proposed Rulemaking on fee calculation, $S: 3$

Reclamation Feasibility Plan, Ap/My:5

Report to Congress on the Reassessment of the Civilian Radioactive Waste Management Program, Jn:1; S:1; O/N:4
Rethinking High-Level Radioactive Waste Disposal, J/Ag:3, 6; O/N:3

Safety Analysis Report, requirements, Jn:2 Site Characterization Plan, F/Mr:10

Research and development cask development, Ja:3

possible research center for host of waste facility, Ap/My:1

regulatory compliance in waste package design, $\mathrm{F} / \mathrm{Mr}: 4$

use of lead in repository waste package, F/Mr:4 waste disposal technologies, Ap/My:4

\section{Reynolds Electric and Engineering Company,} $\mathrm{O} / \mathrm{N}: 5$

\section{Right-of-Way-Reservation (ROWR), O/N:4}

Risk communication, Ap/My:4; J1/Ag:2, 3

\section{Safety}

as guiding principle, $S: 1$

and performance standards, J/Ag:3

public and environmental safety workshop,

$\mathrm{O} / \mathrm{N}: 4$

and public perceptions, Ap/My:4

radiation, $\mathrm{Jn}: 3$

and radiation protection standards, F/Mr:10

recommendations by NWTRB, F/Mr:9

transportation, Jn:2

Sandia National Laboratories, Ja:3; O/N:5

Savannah River Laboratory, Jl/Ag:5

\section{Schedule}

and delays, F/Mr:1-2; Ap/My:2

and postponement of quality assurance audits, Jn:6

for prototype drilling, Jn:4

recommendations by National Research Council, $\mathrm{Jl} / \mathrm{Ag}: 3$

for repository program, Ja:2; F/Mr:10; Jn:6

for restructured radioactive waste management program, S:2

for site investigation, Jn:1

for spent fuel acceptance, Ap/My:1; Jn:2; O/N:5 


\author{
Science education \\ importance of, F/Mr:4; S:5 \\ initiatives, $\mathrm{O} / \mathrm{N}: 3$ \\ OCRWM graduate fellowship program, S:5; \\ $\mathrm{O} / \mathrm{N}: 3$ \\ partnerships, S:5
}

Scientific investigations, F/Mr:5, 11; Jn:1; S:4;

$\mathrm{O} / \mathrm{N}: 1$ (see also Site characterization)

key activities, figure $\mathrm{O} / \mathrm{N}: 2$

near-term emphasis on identification of potentially unsuitable site conditions, $\mathrm{O} / \mathrm{N}: 1$

\section{Secretary of Energy's Energy Advisory Board, $\mathrm{O} / \mathrm{N}: 1-2$}

\section{Senate Committee on Appropriations, F/Mr:4}

Site characterization, F/Mr:1; Jn:4 (see also

Scientific investigations)

and biological assessment of desert tortoise,

$\mathrm{F} / \mathrm{Mr}: 8$

environmental program, Ap/My:5

focus on key suitability issues, $\mathrm{F} / \mathrm{Mr}: 2$

and historic preservation, $\mathrm{F} / \mathrm{Mr}$ : 11

litigation by State of Nevada, Ja:1

progress report, F/Mr: 10

and quality assurance audits on controls, $\mathrm{O} / \mathrm{N}: 5$

studies and need for required permits, Ja:2;

F/Mr:2

surface-based tests, F/Mr:2

training programs to protect archaeological and historic resources, F/Mr: 11,13

Site selection, repository, Ap/My:1

grants and tax incentives, $\mathrm{S}: 5$

opportunity for negotiated site, $S: 4-5$

Site selection, Monitored Retrievable Storage

(MRS) facility, F/Mr:2; Ap/My:1

\section{Spokesmen}

DOE Representatives

Watkins, J.W., Ja:1-2; F/Mr:5; S:1

Bartlett, J., Ja:1; Jn:1, 2; Jl/Ag:4; S:1, 4

Rousso, S., Ap/My:1

Office of the Nuclear Waste Negotiator

Leroy, D., Jn:1; O/N:1
State of Nevada, F/Mr:10

Nuclear Waste Project Office, F/Mr:8

and quality assurance oversight, $\mathrm{O} / \mathrm{N}: 5$

Subcommittee on Nuclear Regulation of the Senate Committee on Environment and Public Works, O/N:1

Subseabed disposal, Jl/Ag:3

Systems engineering, development, and management, J1/Ag:5

Technical exchanges, F/Mr:10

Testimony, Congressional, by Bartlett, J.W., $\mathrm{O} / \mathrm{N}: 1$

Training, Jn:2; S:2; O/N:3

TRANSNET (computer code), F/Mr:9

Transportation (see also Reports)

cask design

capacity, Ja:3

certification, Ja: 3

"from-reactor" casks, Ja:3

legal-weight truck cask, Ja:3

overweight truck cask, Ja:3

rail/barge design, Ja:3

cask development, $\mathrm{F} / \mathrm{Mr}: 8 ; \mathrm{O} / \mathrm{N}: 1$

cask certification, $\mathrm{F} / \mathrm{Mr}: 8 ; \mathrm{Jn}: 2$

cooperative agreement with Conference of

Radiation Control Program Directors, J/Ag:5

defense high-level waste, Ja:3

directory of State agencies, J/Ag:5

identification of routes, $\mathrm{Jn}: 2$

independent review of OCRWM plans, $\mathrm{O} / \mathrm{N}: 5$

institutional issues, $\mathrm{Jn}: 2$

key activities, figure $\mathrm{O} / \mathrm{N}: 3$

legal-weight truck casks, F/Mr:8

Nuclear Waste Technical Review Board

Transportation Panel, public hearing, Jl/Ag:4

plan for safety during increased spent fuel

shipments, Jn:2

program planning, $3, \mathrm{Jn}: 2$

proposed safety program, F/Mr:9

rail/barge casks, F/Mr:8 
rate of spent fuel shipments, Jn:2

reduction in cask design studies, F/Mr:7

review team head, Dr. Edward Bentz, O/N:5

safety, Jn:2

seminar on design and development of transport casks, Ja:2

system design, $\mathrm{O} / \mathrm{N}: 5$

technical assistance to American Indian Tribes, S:4

\section{Transportation Coordination Group}

Albuquerque, New Mexico meeting, O/N:5 Lexington, Kentucky meeting, Ja:2; F/Mr:8 and National Congress of American Indians, S:4

Transportation Legislative Data Base (TLDB), Ap/My:5

Transportation program activities, figure $\mathrm{O} / \mathrm{N}: 3$

Tribal issues (see American Indian Tribes)

TRW Environmental Safety Systems, Inc. (TRW), Jl/Ag:5

U.S. Bureau of Mines, F/Mr:4

U.S. Fish and Wildlife Service (FWS), F/Mr:8

U.S. Geological Survey (USGS), O/N:5

Utilities Transportation Working Group, F/Mr:8

Waste acceptance, Ap/My:1; Jn:2; O/N:5

Waste Isolation Pilot Plant (WIPP), F/Mr:1

Waste package, use of lead, F/Mr:4

Westinghouse Electric Corporation, Ja:3
Yucca Mountain Information Office, Ja:2

Yucca Mountain Project (1990 terminology), $\mathrm{F} / \mathrm{Mr}: 8$

equipment testing, Jn:4

and information offices, Ja:2

and quality assurance, $\mathrm{Jn}: 1$

Update Meeting, Ap/My:2

Yucca Mountain Project Office (1990

terminology for the present Yucca Mountain

Site Characterization Project Office),

F/Mr:3, 11

Yucca Mountain site, F/Mr:6; O/N:1

and assertion of disapproval by State of Nevada, $\mathrm{O} / \mathrm{N}: 4$

and desert tortoise, F/Mr:8

and environmental permit applications, Ja:1-2

examination of potentially unsuitable conditions, $\mathrm{O} / \mathrm{N}: 1$

historic preservation at, $\mathrm{F} / \mathrm{Mr}: 11$

hydrogeology, F/Mr:5, 9

inapplicability of lead-based foreign waste package designs at, $\mathrm{F} / \mathrm{Mr}: 4$

independent review, $\mathrm{Ja}: 2$

and proposed radionuclide adsorption workshop, $\mathrm{F} / \mathrm{Mr}: 9$

prototype drilling equipment for, $\mathrm{Jn}: 4$

and quality assurance audits on controls, $\mathrm{O} / \mathrm{N}: 5$

and radionuclide retention in potential repository, $\mathrm{Jl} / \mathrm{Ag}: 4$

reclamation, Ap/My:5

schedule for repository operation, Ja:2

site suitability, Ja:2; F/Mr:2; Ap/My:1, 3; S:1

surface-based tests, $\mathrm{F} / \mathrm{Mr}: 2$

technical and scientific recommendations, F/Mr:5, 9, 10 


\section{Status of Nuclear Waste Policy Act Related Litigation}

Supreme Court refuses to hear Nevada's appeal; lets stand Ninth Circuit decision favoring DOE. ("Notice of Disapproval Case")

In a petition in the U.S. Court of Appeals for the Ninth Circuit filed on Jan. 5, 1990 , the State of Nevada challenged the DOE decision to conduct scientific investigations at Yucca Mountain, as a potential site for the location of a national high-level radioactive waste repository, pursuant to the Nuclear Waste Policy Act of 1982, as amended (NWPA). Nevada asserted that Congress' selection of Yucca Mountain was not constitutional, and that actions by the Nevada State Legislature constituted a valid and effective "notice of disapproval" pursuant to the NWPA. Nevada finally contended that the Secretary of DOE must promulgate regulations that govern the timing of site disqualification decisions. On Sept. 19, 1990 , the Court held that Nevada's attempted legislative veto of the Secretary's site characterization activities is preempted by the NWPA, and that the decision to continue site characterization is not contrary to law.

On Dec. 17, 1990, the State of Nevada petitioned the U.S. Supreme Court for a writ of certiorari from the Ninth Circuit Court's decision. On Mar. 4, 1991, the Court denied certiorari and, by so doing, rejected Nevada's legal challenges to DOE's efforts to conduct scientific evaluations of the Yucca Mountain site.
In commenting on the Supreme Court's decision, Secretary of Energy Watkins stated, "The public interest requires that we promptly turn to the task of conducting the scientific evaluation of the Yucca Mountain site, as the law mandates...We would welcome a cooperative and constructive approach with officials at all levels in the State of Nevada."

Complaint by DOE that the State of Nevada has unlawfully refused to act on DOE's environmental permit applications. ("Permits Case")

On Jan. 25, 1990, the Department of Justice, at DOE's request, filed a suit in theU.S. District Court,District of Nevada, contending that Nevada has prevented DOE from carrying out necessary scientific investigations to determine the Yucca Mountain site's suitability for a nuclear waste repository by unlawfully refusing to act on DOE's environmental permit applications. On May 23, 1990, the District Court granted a State motion to stay the proceeding pending resolution of the "notice of disapproval" case described above. After the U.S. Court of Appeals decision in the "notice of disapproval" case, DOE permit applications were returned to the State on Oct. 1, 1990, and DOE filed a motion for summary judgment on Oct. 4, 1990. Nevada filed a motion to maintain the stay on Oct. $2 \dot{3}, 1990$, on the basis of its petition for certiorari to the U.S. Supreme Court.
Following the Supreme Court decision in the "notice of disapproval" case, the Nevada Division of Environmental Protection requested, in a letter dated Mar. 12, 1991, that DOE resubmit applications for surface disturbance and

(Continued on page 2)

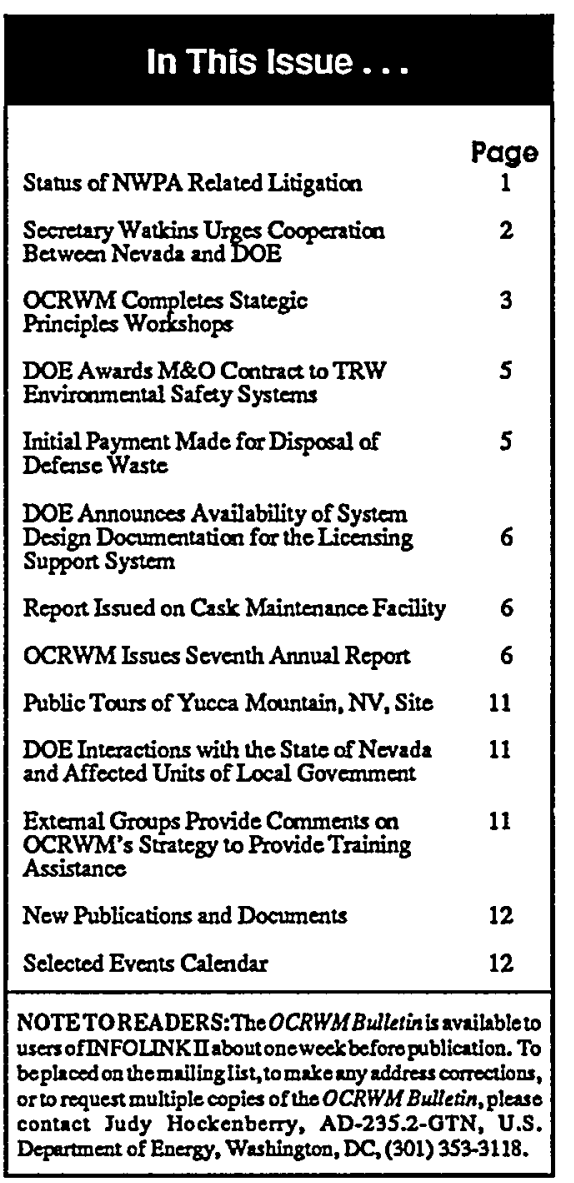

Publlshed by the U.S. Department of Energy (DOE), Office of Civillan Radioactlve Waste Management (OCRWM)

For further information about the national program or for copies of new OCRWM publications and documents listed in the OCRWM Bulletin contact the U.S. Department of Energy, OCRWM, Office of External Relations, Mail Stop RW-5.1, 1000 Independence Avenue, S.W., Washington, DC 20585, (202) 586-5722. The OCRWM Information Services Directory is available to provide sources of program information. 


\section{Secretary Watkins Urges Cooperation Between Nevada and DOE}

On Mar.4, 1991, the U.S. Supreme Court denied Nevada's request that the Court review last September's decision by the U.S. Court of Appeals for the Ninth Circuit. This decision rejected Nevada's legal challenges of DOE's efforts to conduct scientific evaluations of the Yucca Mountain site as a potential nuclear waste repository (see page 1 of this Bulletin for more details of this case). Subsequent to thatdecision, Secretary of Energy Watkins wrote the following letter to Governor Bob Miller of Nevada to urge cooperation between Nevada and DOE.

"Now that the United States Supreme Court has let stand the decision of the Ninth Circuit Court of Appeals in Nevadav. Watkins, the way is clear for us to join in ensuring the fulfillment of Congress' mandate to objectively evaluate the suitability of the Yucca Mountain site as a potential location for a high-level waste repository. I am writing tourge cooperation between the
State of Nevada and the Department of Energy in this process.

"In response to prior recommendations from the State of Nevada and others, the Department has prioritized its plans for scientific evaluation activities in order to determine as rapidly as possible if the site is qualified or disqualified as a potential repository location. The Department has also established its readiness to proceed expeditiously in this process; has put into place both policy and capability to make raw data available to the State of Nevada and others as soon as possible; has committed to a policy of open, external review of technical plans and findings by expert groups such as the Nuclear Waste Technical Review Board; and has begun development of the bases for ultimately making a suitability evaluation, using a policy of external reviews.

"The Department has taken significant steps upon which a strong and effective partnership with your State in the Yucca Mountain site evaluation process can take place. We have established a community of professional expertise and critique which, through national and international oversight activities, draws on worldwide personnel of the highest capabilities in all relevant disciplines to help assure that our environmental, technical, and socioeconomic work is sound. We would welcome the input of the professional resources of the State of Nevada as a partner in this process.

"I firmly believe that expeditious action to move forward with evaluation of the Yucca Mountain site is not only the Department's mission as established by law but will serve the best interests of the State of Nevada. I stand ready to work with Nevada, and I look forward to your joining mein seeing to it that the objective evaluation of the Yucca Mountain site is successfully completed." 文

\section{Status of Nuclear Waste Policy Açt Related Litigation (continued from page 1 )}

underground injection control (UIC) permits. DOE resubmitted the permit applications on Mar. 20, 1991.

In a hearing held on Mar. 20, 1991, the U.S. District Court in Las Vegas, NV, ordered that:

1) The State and the DOE should submit a stipulation (mutual agreement) by Apr. 22, 1991, providing that the pending applications will be expeditiously processed in accordance with State law on the merits, and will not be denied for any reason disposed of by the U.S. Court of Appeals of the Ninth Circuit.

2) Final action on the air quality permit application and final action on the UIC permit application will take place by June 3,1991 .
3) A hearing will be held on July 17,1991 , to report on processing of the water appropriation permit application.

Request by County of Esmeralda, $N V$, and County of Inyo, CA, for designation as affected units of local government

OnFeb. 20,1991, theU.S.Court of Appeals for the Ninth Circuit, in consolidated cases filed by Inyo County, CA, and Esmeralda County, NV, vacated the decision by the Secretary of Energy not to designate the counties as "affected units of local government" under the NWPA and remanded the cases to DOE for further action.

The NWPA provides that the Secretary of Energy has discretion to designate counties that are contiguous to the Yucca Mountain siteas "affected units of local government."
The funding provisions of the NWPA require DOE to make grants to affected units (see article on page 11 about Clark, Nye and Lincoln Counties in this Bulletin). In its decision, the Court ruled that it could review whether DOE "meaningfully consider(ed) the possibility and extent of the suggested impacts of repository operations at Yucca Mountain upon the counties at issue and made a reasoned decision based upon such consideration."

The Court found merit to the Counties' arguments that DOE did not adequately consider the possibility of groundwater or airborne contamination in Inyo County, and transportation by rail and highway of wastes through Inyo and Esmeralda Counties to the repository. $t$ 


\section{OCRWM Completes Strategic Principles Workshops}

On Apr. 3-4, 1991, in Denver, CO, OCRWM held its third workshop on waste management policies and strategic principles. In the first workshop, convened in Salt Lake City, UT, on Dec. 4-5, 1990, the discussion focused primarily on strategic principles related to ensuring public safety and protecting the environment. The second workshop, held in Washington DC, on Jan. 15-16, 1991, dealt with the stewardship of resources and effectiveness of operations.

The Denver workshop concentrated on the approach that OCRWM plans to take regarding the issues discussedat the earlier workshops. The results of these workshops will be considered in preparing an amended Mission Plan to be issued later this year. The amended Mission Plan, currently under development, will be based on policies and strategic principles that, when adopted in final form, will be used to guide program implementation.

Strategic principles discussed at the workshops and suggested by the participants are presented below. These principles will provideaguidé fordecision making and development of more detailed plans and studies needed by OCRWM to successfully conduct waste management activities.

\section{Management Principles}

Maintain the focus of the program on permanent disposal.

Disposal is the primary objective, it is the DOE's principal responsibility under the law, and success in achieving it is vital to maintaining the nuclear energy option. All program activities must be'conducted in a manner that supports and facilitates permanent disposal.

\section{Providefacilitiesfor the timely acceptance} of spent fuel.

Thisprincipleiscritical toachieving timely and adequate waste acceptance and obtaining the system development and operational benefits that have been identified for a Monitored Retrievable Storage (MRS) facility, including the flexibility essential for spent fuel management.

\section{Maintain strictenvironmental compliance programs.}

Preliminary analyses indicate that the development of facilities and waste management and disposal operations are not likely to result in significant environmental impacts. Nonetheless, this principle is important because its implementation will ensure that we give environmental protection priority and that we closely monitor field activities for compliance with all applicable environmental protection standards.

Ensure that funds are spent in a cost effective manner.

Given that standards of excellence are established and applied, we must maintain effective means for controlling the costs of the program. This principle will be based on optimizing the use of resources over the long term, recognizing potential impacts on the waste-management efforts of the utilities, and evaluating potential impacts on public confidence.

\section{Maintain standards of excellence.}

Technical excellence has always been a fundamental requirement of the program, and its importance increases with the increasingly difficult challenges as the program moves forward. It is essential for success in licensing, establishing scientific consensus, increasing public confidence, and the prudent management of resources. We will apply standards of excellence to all aspects of the program, including institutional activities, outreach, and management.

Ensure that all quality assurance requirements are met.

Quality assurance comprises the planned and systematic actions necessary to provide adequate confidence that the product or result of an activity covered by the quality assurance program will meet its intended purpose and/or function; it is a prerequisite for licensing. The extent to which quality assurance and procedural controls will be applied to particular items and activities will depend upon their relative importance to safety, waste isolation, or program objectives.

\section{Consider public trust and confidence in} program decisions.

In making management, technical, and institutional decisions for the program, we must recognize the importance of public concernsand consider the potential implications for building and maintaining public trust and confidence.

Assign equal importance to institutional and technical activities.

The history of the program has shown that institutional challenges are as difficult as the technical ones, and we must recognize their importance in program plans, activities, and resource applications.

Diminish uncertainties related to spentfuel management by utilities.

We will identify system parameters that may affect utility efforts or plans for spent fuel management as early as practicable. We will maintain effective channels of communication with the utilities.

\section{Provide alternatives and contingency} plans.

We need this principle to ensure success despite the inevitable surprises and unexpected problems that will arise in a complex, first-of-a-kind enterprise. It requires that we analyze in parallel, alternatives to key components of the system so that if the primary candidate site encounters difficulties, we can come up with a workable alternative with minimal delay. It also requires that we anticipate the difficulties which might be encountered, and that we develop, in advance, plans for minimizing their effects. While the provision of backups (Continued on page 4) 


\section{OCRWM Completes Strategic Principles Workshops \\ (Confinued from page 3)}

'and contingency planning increase the initial costs of the program, they are insurance against unforeseen problems that could otherwise lead to delays and real or perceived programmatic failure.

Coordinate the technical, institutional, and management activities of the program.

Implementation of this principle should enhance the integration of technical and institutional activities, contribute to the control of program schedules, and enhance theprospects for the success of the mission.

Assess our own performance rigorously. It is notenough to havepolicies, objectives, and strategic principles to guide decisionmaking; they have to be used. To objectively determine the adequacy of our performance and how it can be improved, we will maintain an assessment program. We will apply performance measures systematically and periodically to determine how we can remedy inadequacies and further strengthen our efforts.

\section{Technical Principles}

Apply the concept of defense-in-depth in waste management and disposal.

We will emphasize safety in the design and planning for all operations involving waste handling, including backup safety systems and fail-safe designs where appropriate, and use multiple barriers against waste migration. This approach should facilitate licensing and help to establish public confidence in safety.

Use state-of-the-art systems engineering techniques in developing and designing waste-management facilities and operations.

Systemsengineering is an orderly process for the development of complex systems. It consists of defining objectives and requirements, developing a design that meets the requirements, evaluating the design against the requirements, revising the design as needed, and repeating the process with increasing detail to ensure that the requirements are complete and satisfied by thesystem and its components. Important features of the process are its emphasis on ensuring that all the components work together, on special studies of the entire system's ability to meet requirements, and on rigorous control of the technical information used in the process. Systems engineering is essential for the success of the program because it provides the means for identifying, controlling and coordinating the many interfaces among the elements of the system, coordinating the multiple scientific and engineering disciplines involved in the program, and optimizing the design and operation of the system.

Use simple and proven designs and technologies.

The use of simple and proven technologies, particularly those already licensed by the Nuclear Regulatory Commission, and the use of designs that approximate those of licensed facilities should facilitate licensing and increase cost effectiveness. This principle is applicable to a Monitored Retrievable Storage (MRS) facility, a repository, and a transportation system.

\section{Provide for outside review.}

The purpose of this principle is to ensure that, in resolving important issues and making important decisions in the program, we have the benefit of appraisal by outside experts. Such appraisal, which includes peer reviews, is important in verifying orvalidatingassumptions, plans, results, or conclusions critical to the success of aprogram. It bolsters technical confidence, and may also generate fresh ideas and approaches to problems. Further, the useofrecognized independent authoritiesstrengthens our credibility. We will not limit the outside reviews to technical issues; we will extend them to institutional and managerial issues as well.

\section{Institutional Principles}

Provide for the involvement of affected governments and interested parties in the decisionmaking process.

As the organization charged with the development of the waste management system, we have certain responsibilities that cannot be shared. One of these responsibilities is making technical and programmatic decisions. However, the views of affected governments and interested parties are essential to the decisionmaking process and will be actively solicited. The involvement of affected governments and interested parties early in the decisionmaking process will help us identify emerging issues and formulate appropriate alternatives. This will make issueresolution moreproductive and will also allow the program to benefit from the knowledge and experience of the affected parties.

Work cooperatively with affected governments and interested parties.

To foster productive links with affected governments and interested parties, we will consult and cooperate with them and will seek to exchange information and ideas. We will use cooperative agreements to bring additional groups into the program, both for technical advice and for the dissemination of information to their members.

\section{Share information and data.}

We will share technical information and data on a timely basis and in an appropriate form.

\section{Provide support to educational programs.}

Greater understanding of the health, safety, and environmental issues surrounding waste generation and management is key to the success of the program. It is also needed to help develop the skillsnecessary to meet the future human resource needs of the program. We will implement this principle by stimulating the teaching of

(Continued on page 5) 


\section{DOE Awards M\&O Contract to TRW Environmental Safety Systems}

DOE has awarded a management and operating (M\&O) contract to TRW Environmental Safety Systems (TESS) for systems engineering, development, and management of the nuclear waste management system for OCRWM. The contract has a ten-year term. The award to TESS for the first six months is $\$ 15.8$ million. After the initial ten-year period, the contract is subject to DOE's review of contractor performance. A decision whether to renew the contract for up to five additional years will be made at that time. The negotiations and award of this contract are in accordance with a ruling of the U.S. Claims Court (see OCRWM Bulletin, July/August 1990).

In announcing this award, OCRWM Deputy Director Franklin G. Peters stated, "A management and operating contract is needed to consolidate and improve integration and direction of the OCRWM program resources and to proceed with program priorities. The $\mathrm{M} \& \mathrm{O}$ contractor

will provide the additional expertise that is necessary to implement this complex program. The contract will facilitate the implementation of the restructured OCRWM program as announced by Admiral Watkins in his Report to Congress in November 1989. Having an M\&O contractor on board will allow us to effectively respond to previous Congressional concerns about lack of integrated contractor efforts, and industry concerns about duplicative contractor support and the need to selcct contractors

\section{Inifial Payment Made for Disposal of Defense Waste}

The Nuclear Waste Policy Act of 1982 (NWPA) required the President toevaluate whether high-level wastes generated by atomic energy defense activities should be disposed of in a geologic repository along with commercial nuclcar wastes. In February 1985, the Sccretary of Energy

\section{OCRWM Completes Strategic Principles Workshops}

\section{(Confinued from page 4)}

science at the secondary, undergraduate, and graduate levels and by developing curricula and instructional materials-both print and electronic - for primary, secondary, and undergraduate studies. A related effort will be to foster undergraduate and graduate studies for the public policy aspects of waste management.

Evaluate socioeconomic issues in cooperation with affected governments.

We will apply standards comparable to those applied to environmental and technical issues, including independent review, to socioeconomic effects. And we will seck the cooperation of affected governments to ensure that we consider significant local issues.
In siting, designing, and constructing waste-management facilities, consider potential benefits to the host States and communities.

The Nuclear Waste Policy Act of 1982 as amended (NWPA) requires the Secretary of Energy, in siting Federal research projects, to give special consideration to proposals from States where a repository is located. Italso authorizes the Secretary of Energy toenter intoa bencfitsagreement with the State of Nevada concerning a repository or with any State or Indian Tribe conceming an MRS facility. Such a benefits agreement would include specific benefits, including enhanced program participation, identified in the NWPA. Other benefits to jurisdictions willing to hostarepository orMRS facility could be developed through the Nuclear Waste Negotiator. who have successfully integrated very complex programs in the past. The TESS team, which includes Babcock \& Wilcox, Duke Engineering, Flour Daniel, INTERA, Morrison-Knudsen, Woodward-Clyde Consultants, RDA, E.R. Johnson Associates, and J.K. Associates, willalsoprovide the requisite contractor capability to proceed with advanced design of a Monitored Retrievable Storage facility. This resource was not previously available in the OCRWM program."

sent a report (An Evaluation of Commercial Repository Capacity for the Disposal of Defense High-Level Waste, DOE/DP/0020/1, June 1985) to the President recommending that defense wastes be commingled with commercial nuclear waste rather than building separate repositories. The President, on April 30, 1985, advised the Secretary of Energy that defense waste and commercial spent nuclear fuel should be disposed of in the same repository.

As directed by the NWPA, the costs resulting from the disposal of defense high-level waste (DHLW) must include "the allocation of costs of developing, constructing, operating and decommissioning" the repository or repositories where $D H L W$ is placed. The principle underlying this statutory direction is that users of a repository, whether civilian or federal, pay for that use. Neither the taxpayer paying for DHLW disposal nor the ratepayers of nuclear utilities paying for disposal of spent nuclear fuel are intended to subsidize one another.

DOE issued a final notice in the Federal Register, on August 20, 1987 (51 FR 43566), which stated that the cost allocation methodology for calculating defense high-level waste fees will be fullcost recovery based on facility usage and activities performed. Therefore, the total

(Continued on page 6) 


\section{DOE Announces Availability of System Design Documentation for the Licensing Support System}

Final computer system design documentation for the Licensing Support System (LSS) is now available to the public in the DOE's Freedom of Information reading rooms at the $\mathrm{DOE}$ Headquarters Building at 1000 Independence Avenue, S.W., Washington DC, and at the Nevada Operations Office in Las Vegas, NV.

The LSS will be used to support the Nuclear Regulatory Commission's process for review of DOE's license application for construction of a geologic repository for high-level radioactive waste. It is an electronic information system intended to contain the documentary material of the license applicant, DOE, its contractors, and documentary material of all other parties, interested governmental participants and potential parties and their contractors. The ISS will provide a mechanism fordocument discovery during the licensing proceedings, a means for electronic submission of filings by the parties, and for the dissemination of findings of the Commission and its

OCRWMIssues seventh Annuall Report

A description of OCRWM activities and expendinures during the Fiscal Years 1989 and 1990 is contained in. the seventh Annital Report for the OCRWM prograñ

Because the Balance sheets tor the OCR WM p nogram have not yet been published in the ockW Bulletin they are presented on pages 7.10 . For copies of the fill report contact the US.Departmentof chetgy, OQRWM office of External Relations Mail Stop RW 5,01 , 10001 Independence avenue. $\mathrm{SW}$ Washingtón $\mathrm{DC} 20585$ or call (202)586-5722 adjudicatory boards during the proceedings.

The system design documentation responds to preliminary conceptual design developed for $D O E$ for continued detailed design efforts. The documents available for public review include: the Licensing Support System Search and Image Design Document:VolumesIandII: the Licensing Support Communication System Design Document, and the Licensing Support Capture System Design Document. In addition, two volumes which discuss assumptions made in the design, the Licensing Support System-System Level Requirements Document and a series entitled White Papers for the Licensing Support System, will be made available. No procurement actions by the DOE, based on these design documents are anticipated.

For further information, contact Daniel J. Graser, U.S. Department of Energy, Office of Civilian Radioactive Waste Management, RW-12, Washington, DC 20585 , or call (202) 586-4589.

\section{Report Issued on Cask Maintenance Facility (CMF)}

Oak Ridge National Laboratory, under contract with OCRWM, recently issued a report, Feasibility Study for Transportation Operations System Cask Maintenance Facility (ORNL/TM-11019). The report discusses the role of a CMF within the transportation system as well as preliminary costs, design specifications and schedules. This study provides a basis for initiating the conceptual design of a CMF.

A CMF would be an integral part of the OCRWM program. The design and siting of a CMF will be integrated with other elements in the OCRWM program, including the monitored retrievable storage (MRS) facility, the geologic repository, and the components of the

transportation cask system. The CMF could be co-located with an existing DOE facility, located as part of the repository or MRS, or developed as a stand-alone facility.

A CMF would centralize maintenance operations for casks used to transport spent nuclear fuel and high-level radioactive waste to a geologic repository or an MRS facility. Primary CMF functions listed in the report include inspecting, servicing, testing, and repairing cask components. The CMF could also provide for the reconfiguration of casks to accommodate different spent fuel baskets. ACMFcould also be used to prepare casks or cask components, that are no longer fit for service, fordecommissioning and disposal.

(Continued on page 11)

\section{Inifial Payment Made for Disposal of Defense Waste (Continued from page 5)}

cost of developing a disposal system will be shared between the defense and commercial sectors, with common variable repository costs allocated on the basis of the following cost sharing factors: (1) areal dispersion and (2) piece count.

Discussions are under way to develop a Memorandum of Agreement between OCRWM and DOE's Office of
Environmental Restoration and Waste Management detailing the specific terms and conditions for accepting and paying for the disposal of $\mathrm{DHLW}$. Prior to finalizing that agreement, however, DOE has now made an initial payment of five million dollars into the Nuclear Waste Fund for the disposal of defense nuclear waste. 
NUCLEAR WASTE FUND

OFFICE OF CIVILIAN RADIOACTIVE WASTE MANAGEMENT UNITED STATES DEPARTMENT OF ENERGY

Balance Sheets

September 30, 1989 and 1988

(Dollars in thousands)

Assets

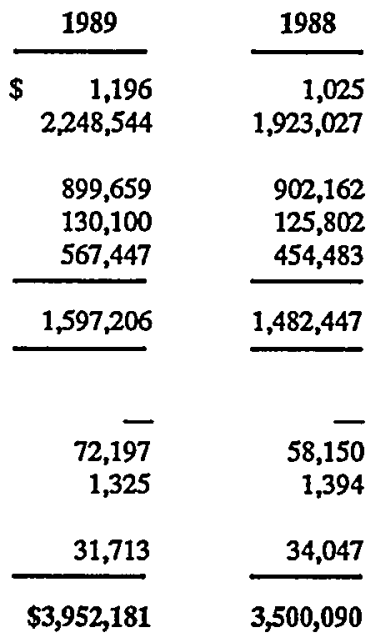

\section{Cash}

U.S. Treasury securities

Receivables from utilities:

One-time spent fuel fees

KWH fees

Interest on one-time spent fuel fees

Receivable from Department of Energy for defense

high-level waste disposal costs

Accrued interest on U.S. Treasury securities

Other receivables and advances

Capital equipment, less accumulated depreciation of $\$ 20,019$ in 1989 and $\$ 16,495$ in 1988

Liabilities

Accounts payable and accrued expenses

Estimated payable to utilities on overpayment of KWH fees

Deferred revenue

Total liabilities

\begin{tabular}{rr}
67,508 & 42,706 \\
200,000 & - \\
$3,684,673$ & \\
\hline $3,952,181$ & $3,557,384$ \\
- & \\
\hline 3 3,952,181 & $3,500,090$
\end{tabular}

Fund balance

Contingencies

$3,500,090$ 
NUCLEAR WASTE FUND

OFFICE OF CIVILIAN RADIOACTIVE WASTE MANAGEMENT

UNITED STATES DEPARTMENT OF ENERGY

\section{Statements of Operations}

Years ended September 30, 1989 and 1988

and cumulatively from January 7,1983 , date of inception

to September 30, 1989

(Dollars in thousands)

\begin{tabular}{|c|c|c|c|}
\hline & 1989 & 1988 & Cumulative \\
\hline \multicolumn{4}{|l|}{ Revenue: } \\
\hline \multicolumn{4}{|l|}{ Fees: } \\
\hline One-time spent fuel fees & 一 & (196) & $2,334,777$ \\
\hline KWH fees & 317,186 & 515,724 & $2,508,535$ \\
\hline \multicolumn{4}{|l|}{ Interest: } \\
\hline One-time spent fuel fees & 116,490 & 84,450 & 583,215 \\
\hline U.S. Treasury securities & 169,304 & 141,586 & 608,697 \\
\hline \multicolumn{4}{|l|}{ Gain (loss) on sale of U.S. Treasury } \\
\hline & 602,848 & 745,258 & $6,067,405$ \\
\hline \multirow[t]{2}{*}{ Less amount deferred } & $(227,289)$ & $(357,227)$ & $(3,684,673)$ \\
\hline & 375,559 & 388,031 & $2,382,732$ \\
\hline \multicolumn{4}{|l|}{ Expenses: } \\
\hline First repository & 237,306 & 294,695 & $1,761,618$ \\
\hline Second repository & 989 & 8,126 & 108,610 \\
\hline Monitored retrievable storage & 1,567 & 1,374 & 39,766 \\
\hline \multicolumn{4}{|l|}{ Transportation and systems } \\
\hline integration & 38,269 & 31,432 & 116,380 \\
\hline Program management & 93,395 & 44,741 & 334,362 \\
\hline Interest & 45 & 7,663 & 18,008 \\
\hline \multirow[t]{2}{*}{ Transfer appropriation } & 3,988 & - & 3,988 \\
\hline & 375,559 & 388,031 & $2,382,732$ \\
\hline Excess of revenue over expenses & $\$$ & - & 一 \\
\hline
\end{tabular}


NUCLEAR WASTE FUND

OFFICE OF CIVILIAN RADIOACTIVE WASTE MANAGEMENT UNITED STATES DEPARTMENT OF ENERGY

\section{Statements of Changes in Financial Position}

Years ended September 30, 1989 and 1988

and cumulatively from January 7,1983 , date of inception

to September 30, 1989

(Dollars in thousands)

Cash provided from:

Revenue received

Expenses paid

Cash provided from

operations

Borrowings from U.S. Treasury

Proceeds from sales and maturities of U.S. Treasury securities

Borrowings from DOE for capital equipment

Total cash provided

Cash used for:

Capital equipment

Repayment of borrowings . from $D O E$ for capital equipment

Repayment of borrowings from U.S. Treasury

Purchase of U.S. Treasury securities

Purchase of accrued interest on U.S. Treasury securities Increase (decrease) in advances

Total cash used

Increase (decrease) in cash

\begin{tabular}{|c|c|c|}
\hline 1989 & 1988 & Cumulative \\
\hline $\begin{array}{rr}\text { S } 733,368 \\
(337,840)\end{array}$ & $\begin{array}{r}694,796 \\
(399,779)\end{array}$ & $\begin{array}{r}4,789,529 \\
(2,270,602)\end{array}$ \\
\hline 395,528 & 295,017 & $2,518,927$ \\
\hline - & 一 & 264,964 \\
\hline 181,112 & 388,579 & $2,265,410$ \\
\hline$=$ & 二 & 9,739 \\
\hline 576,640 & 683,596 & $5,059,040$ \\
\hline 10,450 & 12,369 & 76,202 \\
\hline - & - & 9,739 \\
\hline 一 & 一 & 264,964 \\
\hline 552,416 & 669,679 & $4,689,611$ \\
\hline $\begin{array}{r}13,672 \\
(69)\end{array}$ & $\begin{array}{l}1,126 \\
(307)\end{array}$ & $\begin{array}{r}16,003 \\
1,325\end{array}$ \\
\hline 576,469 & 682,867 & $5,057,844$ \\
\hline 171 & 729 & 1,196 \\
\hline
\end{tabular}




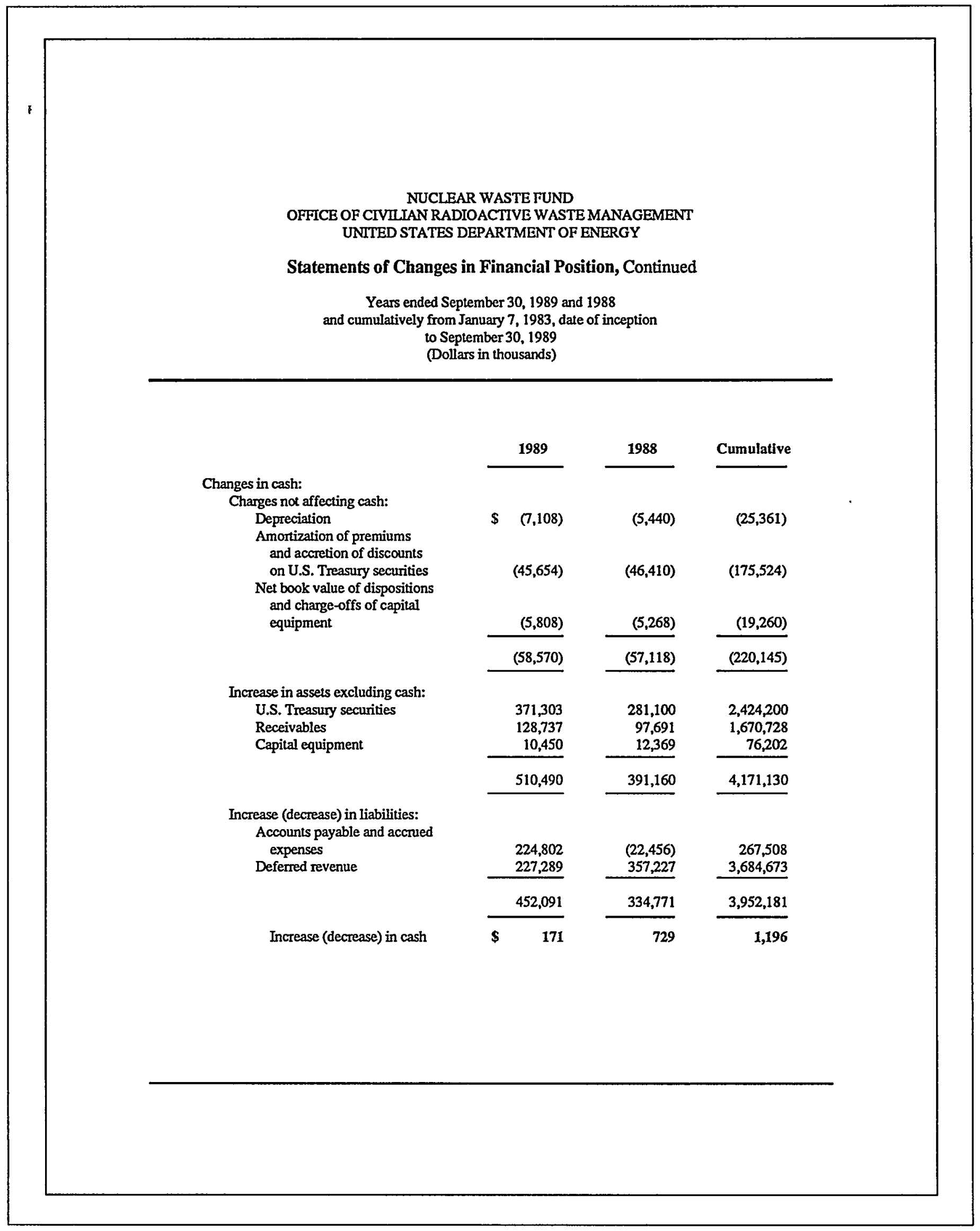




\section{Public Tours of Yucca Mountain, NV, Site}

More than 325 people toured the Yucca Mountain, NV, area on March 23, 1991, as guests of the DOE's high-level nuclear waste repository site characterization project. The tour and open house featured stops at the newly-remodeled Facility OperationsCenter, where management of new field work will be headquartered; and at Yucca Mountain itself, where Project scientists told visitors about the studies that will be conducted to determine the suitability of the Yucca Mountain site as a repository. Other stops included a hydrology laboratory and a facility for housing rock and environmental samples, as well as the actual location where new field work will begin.

Buses picked up visitors in Las Vegas and two locations in Nye County where the site is located, for the day-long event. Guests were members of the public who had asked to take the tour. The tour was advertised in local newspapersand through DOE mailing lists, and more than 1,200 calls were received in one week. Because of the overwhelming public response, a second open house was conducted on Apr. 20, and subsequent tours will take place on May 10 and June 8, 1991 .

\section{Report Issued on Cask Maintenance Facility (CMF) (Continued from page 6)}

In additiontocask service and maintenance, a CMF could also be used to maintain an inventory of equipment, tools, and handling devices, and spare parts, and also provide for the temporary storage of unloaded casks. Maintenance equipmentand facilities to perform basic services such as the decontamination and repainting of transport vehicles such as trailers and railcars could also be incorporated at the facility.

Copies of the Feasibility Study for a Transportation Operations System Cask Maintenance Facility are available by contacting: Office of Scientific and Technical Information, U.S. Department of Energy, P.O. Box 62, Oak Ridge, TN 37831, (615) 576-1301.

\section{DOE Interactions with the State of Nevada and Affected Units of Local Government}

Financial Assistance Grants

Pursuant to the Nuclear Waste Policy Act of 1982 as amended, DOE has recently awarded $\$ 3,006,000$ to the State of Nevada, $\$ 2,637,000$ to Clark County, and $\$ 395,779$ to Lincoln County for the conduct of oversight of the scientific investigationsat the Yucca Mountain, NV, candidate site. The funding request for Nye County is under review.
Framework for Formal Interactions Between Nye County and DOE Signed

Representatives of Nye County and DOE have developed a "framework" document, effective April 2, 1991, for improving and formalizing interactions between the two institutions. This document is the first step in defining the manner in which Nye County and DOE will formally address issues of concern thathavearisen and may arise in the future.

\section{External Groups Provide Comments on OCRWM's Strategy to Provide Training Assistance}

Participants at the Transportation Coordination Group (TCG) meeting held in Albuquerque, NM, Dec. 4-5, 1990, were encouraged to provide comments to DOE on its preliminary draft Strategy to Provide Training Assistance as Required by Section 180(c) of the Nuclear Waste Policy Act of 1982 as Amended. Section 180(c) of the NWPA states that "the Secretary [of Energy] shall provide technical assistance and funds to States for training for public safety officials of appropriate units of local government and Indian Tribes through whose jurisdiction the Secretary plans to transport spent nuclear fucl or high-level radioactive waste..."

Eight institutional groups provided comments on the preliminary strategy. These groupsincluded the Southern States Energy Board; the Western Interstate Energy Board; the National Conference of State Legislatures; the Association of American Railroads; the States of Illinois and Nevada; Lincoln County, NV; and Esmeralda County, NV.

The majorcategories that were addressed in the comments include: defining the scope of the assistance; transportation route designation; the working group; state, local, and industry involvement; Hazardous Materials TransportationUniform Safety Act of 1990; implementation effects; coordination with existingprograms; resolution ofidentified issues; recommendations on actual implementation such as program flexibility, equipment, funding, and course development and contingency planning.

OCRWM is currently revising the preliminary draft strategy. The new draft will reflect the written commentsreceived, input received at the TCG meeting, and information on the inter-agency planning activities under way for the implementation of Section 117a of the Hazardous Materials Transportation Uniform Safety Act of 1990.

No formal response to the comments received on the preliminary draft is planned. Announcement of the next draft will be issued in the Federal Register, and formal comments will be requested. Responses will be prepared for comments received regarding the formal draft. Announcement of the Federal Register notice will be sent to TCG participants. For more information on the status of Section 180(c) planning contact Christopher A. Kouts at (202) 586-9761 or FTS 896-9761. 


\section{New Publications and Documents}

DQE's Yucca Mountain Studies: What are they? Why are they being done?, DOE/RW-0293P, December 1990.

This booklet is about the disposal of high-level nuclear waste in the United States, and is intended for readers who do not have a technical background. It discusses why scientists and engineers think that high-level nuclear waste may be disposed of safely underground. It also describes why Yucca Mountain, $\mathrm{NV}$, is being studied, and provides basic information about those studies. Copies may be obtained by contacting the Yucca Mountain Site Characterization Project, P.O. Box 98608, Las Vegas, NV 891938608, (702) 794-7900.
Information Services Directory, DOE/ RW-0302P, March 1991.

This report is a reference document that lists sources of program information available to States, Indian Tribes, and the public. This is the third update since the Information Services Dircctory was first issued in August 1986.

1990 OCRWM Bulletin Compilation and Index, DOE/RW-0303P, March 1991.

This document is a compilation of OCRWM Bulletin issues for the 1990 calendar year. A table of contents and index have been provided to assist in finding topical information.
Feasibility Study for Transportation Operations System Cask Maintenance Facility, ORNL/TM-11019.

This report discusses the role of a Cask Maintenance Facility within the transportation system as well as preliminary costs, design specifications and schedules. For further description see article on page 6 of this Bulletin.

\section{Selected Events Calendar}

May 20-21 Nuclear Waste Technical Review Board, Risk and Performance Analysis Panel meeting. Arlington, VA. Contact Paula Alford, (703) 235-4473.

End of May Western Interstate Energy Board, High-Level Waste Committee meeting. Location to be announced. Contact Lori Friel, (303) 573-8910.

June 2-5 American NuclearSociety, Annual Meeting, Orlando, FL, Marriott's Orlando World Center. ContactJohn DeMastry, (407) 694-3613.

June 6-7 National Academy of Sciences, Board on Radioactive Waste Managementmeeting, Albuquerque,NM. Contact Betty King, (202) 334-3066.

June 12-13 Licensing Support System Advisory Review Panel Mceting, Bethesda, MD. Contact Marilee Rood, (301) $492-4030$.

June 19-21 Nuclear Regulatory Commission, Advisory Committee on Nuclear Waste meeting, Bethesda, MD. Contact Barbara Jo White, (301) 492-7288.

June 25-27 Nuclear Waste Technical Review Board, Hydrogeology and Geochemistry/Structural Geology and Geoengineering Joint Panel meeting, Arlington, VA. Contact Paula Alford, (703) 235-4473.

July 15-16 Nuclear Waste Technical Review Board, Structural Geology and Geoengineering/Hydrogeology and Geochemistry Joint Panel meeting, Arlington, VA. Contact Paula Alford, (703) 235-4473.

July 16-18 Nuclèar Waste Technical Review Board meeting, Arlington, VA. Contact Paula Alford, (703) 235-4473.

July 24-26 Nuclear Regulatory Commission, Advisory Committee on Nuclear Waste meeting, Bethesda, MD. Contact Barbara Jo White, (301) 492-7288.

For details on DOE/NRC meetings call (1/800) 368-2235 for a recorded message. In the Washington, DC, area call 479-0487.

A telephone recording service has been established for the announcement of upcoming meetings related to the waste management program of the NRC. The number is (1/800) 368-5642, ext. 20436. Washington, DC, area residents should call $492-0436$.

For information on meetings and events occurring between issues of the OCRWM Bulletin use OCRWM INFOLINK II, a computerized data base containing information about the OCRWM program. The OCRWM Bulletin is also available online through INFOLINK II. 


\section{OCRWM Bulletin}

United States Department of Energy

Office of Civilian Radioactive Waste Management

Washington, $D C 20585$

May/June 1991

\section{Secretary of Energy Extends Affected County Status}

Secretary of Energy James D. Watkins has notified Esmeralda, Eureka and White Pine Counties, NV, and Inyo County, CA, that they have been designated as affected units of local government under provisions contained in the Nuclear Waste Policy Act of 1982, as amended. These counties now join Nye, Clark, and Lincoln Counties in Nevada as affected units of local government.

In addition, Dr John Bartlett,

O C R W M

Director, has

not ified

Churchill,

Lander, and

Mineral Counties

in Nevada that they

may wish to request

that the Secretary

designate them as

affected units of local

government in the future.

All of these designated counties are contiguous to Nye County, the local government with jurisdiction over the Yucca Mountain candidate site. This site was chosen by Congress in 1987 for scientific studies to determine its suitability as a potential high-level radioactive waste repository for spent fuel from commercial reactors and highlevel radioactive waste from the Nation's defense programs activities.
The decision by the Secretary of Energy follows a ruling by the Ninth Circuit Court of Appeals in February 1991, concerning extension of affected county status to Esmeralda and Inyo Counties. As designated affected units of local government, Esmeralda, Eureka, Inyo, and White Pine Counties will be eligible to receive financial assistance to oversee the DOE's activities at the Yucca
Mountain candidate site and to mitigate impacts of the scientific investigative activities or potential development of the repository.

\section{In This Issue}

Secretary of Energy

Extends Affected County Status

EPA Presents Views on Legislation to

Permit DOE Site Characterization Without Obtaining State or Local Permits

Litigation Update

DOE and the Office of the Nuclear Waste Negotiator Issue Announcements Regarding the Monitored Retrievable Storage Facility

OCRWM Releases Third Site Characterization Progress Report for Yucea Mountain, NV

Secretary of Energy Writes to Readers of Las Vegas Newspaper

First Meeting Held by the Secretary of Energy Advisory Board Task Force on Civilian Radioactive Waste Management

Financial Statements from OCRWM's Seventh Annual Report

DOE Issues Draft Acceptance Priority Ranking

Nuclear Waste Technical Review Board Releases Its Third Report to the U.S. Congress and the U.S. Secretary of Energy

Selected Events Calendar

Reader Response Card

NOTETO READERS:The OCRWM Bulletin is available to users of INFOLINK about one week beforo publication. To be placed on the mailing list, to mako any address corrections, or to request multiple copies of the OCRWM Bulletin, please contect Judy Hockenberry, AD-235.2-GTN, U.S. Departmeat of Energy, Washington, DC 20545 (301) 353-3118. 


\section{EPA Presents Views on Legislation to Permit DOE Site Characterization Without Obtaining State or Local Permits}

In testimony before the Senate Committee on Energy and Natural Resources on May 13, 1991, the Deputy Administrator of the U.S. Environmental Protection Agency (EPA), F. Henry Habicht II, presented the views of EPA on Section 511 of Senate bill 570 , the Administration's National Energy Strategy Act of 1991. His statement is excerpted below:

"Section 511 amends the Nuclear Waste Policy Act of 1982 to facilitate the Department of Energy's site characterization activities for a high-level radioactive waste repository at Yucca Mountain, Nevada. This section would allow DOE to conduct site characterization activities at Yucca Mountain without the need to obtain permits for such activities from the State of Nevada, a local government, or an Indian Tribe.

\section{Lifigation Upalate}

On May 13,1991 , the U, S District Cout for the District of Nevada ordered that the state fully process the \%oOL applications for underground injection contrôl (UIG) and surfacto disturbance air quality permits by July 17 , 1991 \% The Court has also scheduled a hearning for July $17_{1}$ at which time the state must report on its progiess in processing the DOE wafer appopopriation permit applicationt

On fune 12, 1991, the state issued the atr quality permit, subject to various: restrictions, and also anmounced its. intentionts to issue the tulc permit following a public tearing on this permitscheduled for tuly 16,1991 , in rasyegas

At a conference held in Carson City on fune 13 , 991 ,he State Engined scheduled a heaning concerning the $\mathrm{DOE}$ water appropriation permit applicationto be field Sept 24, 1991, in tas Yegas
"Specifically, Section 511 would withdraw approval under Federal environmental statutes for the State of Nevada to exercise enforcement and administrative authority over site characterization activities. Such authorities would now be exercised directly by EPA under Federal law. The Section would also preempt, in favor of Federal law, all State, Tribal and local laws which impose requirements for permits, rights-of-way, licenses, certifications and approvals.

"Mr. Chairman, EPA endorses this provision because it provides a workable solution to a very difficult and important problem.

"As a matter of general policy, the Bush Administration supports and strongly defends programs of cooperative federalism, whereby Federal and State authorities enforce parallel regulatory schemes. Under such programs, once the State and Federal authorities reach agreement on the substance of the regulatory requirements, the Federal government will look to the State to be principally responsible for enforcement under State law. We believe that the States, in many instances, are better equipped and more capable to carry out public policy programs, particularly environmental protection programs, than the Federal government.

"In fact, it is a fundamental assumption underlying all three Federal environmental statutes most likely to be affected by Section 511 - the Clean Water Act, the Clean Air Act and the Resource Conservation and Recovery Act - that the States will assume principal responsibility for enforcing, as part of State law, all or part of the regulatory program delegation of the States. This is a principle which the EPA and the Administration strongly endorse.
"Nevertheless, the Administration has concluded, in this very limited situation, that the requirement to proceed with site characterization studies at Yucca Mountain mandated by Congress in the Nuclear Waste Policy Act outweighs the general presumption in favor of State administration and enforcement of laws to protect the environment.

"I would note the approach envisioned by Section 511 is analogous to provisions found in all Federal environmental statutes which authorize the President to exempt unilaterally Federal agencies from the requirements of those statutes when he determines it to be in the paramount interest of the United States to do so. The Administration believes that it is in the paramount interest of the United States to proceed on site characterization work at Yucca Mountain as directed by Congress in the Nuclear Waste Policy Act. However, rather than take unilateral action to waive all environmental requirements, Section 511 simply modifies the process through which those requirements are enforced. The legislation ensures that the substantive requirements of our Nation's environmental laws will be met.

"As DOE has testified, the State of Nevada has consistently and effectively thwarted efforts to conduct the scientific investigations mandated by the Nuclear Waste Policy Act. In the absence of a provision such as Section 511, it is possible that those investigations will never occur. Failure to move toward identification of an appropriate site for deep geologic disposal of spent nuclear fuel and high-level radioactive waste means an indefinite continuation of the undesirable practice of storage of such waste at multiple sites.

(Continued on page 3) 


\section{DOE and the Office of the Nuclear Waste Negotiator Issue Announcements Regarding the Monitored Retrievable Storage Facility}

Section 406(b) of the Nuclear Waste Policy Act of 1982, as amended, authorizes the Secretary of Energy to make grants of financial assistance to any State, Indian Tribe or affected unit of local government to assess the feasibility of siting a Monitored Retrievable Storage (MRS) facility at a site under their jurisdiction. On June 5, 1991, OCRWM issued a notice of availability of a restricted eligibility solicitation inviting the submission by eligible States, Indian Tribes and affected units of local government of applications for such grants for studies in order to assess the feasibility of siting an MRS facility under their jurisdiction.

On the same date, the Office of the Nuclear Waste Negotiator published a notice of operating procedures, a notice of intent to coordinate with the DOE on the review and evaluation of financial assistance feasibility grants, and a notice of intent to negotiate agreements with potential host jurisdictions. Requests for more information should be addressed to the Office of the Nuclear Waste Negotiator, 1823 Jefferson Place, N.W., Washington, DC 20036.

The DOE solicitation provides for two types of feasibility study grant applications: Preliminary (Phase 1) and advanced (Phase 2). Preliminary study grants will be for a maximum of $\$ 100,000$ and be based upon conformance with eligibility requirements set forth in the solicitation document. There is no predetermined limit on the amount of an advanced study grant, but such grants as may be awarded will be based upon and determined by the eligibility requirements prescribed in the solicitation.

Applications will be accepted through Dec. 31, 1991, will be processed and acted upon in the order received, if complete, and will be subject to the availability of funds for such purpose at the time of decision on the application. DOE currently has available $\$ 1.097$ million for the purpose of such grants.

Requests for more information and for copies of the solicitation should be made in writing to: Office of Placement and Administration, Attn: Ms. Kristin Wright/PR-322.2, 1000 Independence Avenue, S.W., Washington, DC 20585. Ms. Wright can be reached on (202) 586-4285.

Las Vegas, NV. The PR will be distributed to recipients of the SCP and others expressing interest in receiving it, rather than by automatic distribution to recipients of the OCRWM Bulletin. If you would like to receive copies of the Progress Report, please send a card or brief note to the U.S. Department of Energy, Yucca Mountain Site Characterization Project Office, P.O. Box 98608, Las Vegas, NV 891938518 , so that yournameand address may be added to the distribution list of the Office of Geologic Disposal.
The overall style and format of the third edition of the $P R$ has changed from that of the first two. A description of the status of each Site Characterization Plan (SCP) study activity, and design/performance from Chapter 8 of the SCP is provided. There is also a section on preparatory activities to discuss elements of progress not tied to Chapter 8. Brief discussions of important information or conclusions resulting from site characterization activities are included in the PR, but the PR's main role is to reference where this information can be found in the literature. The PR also reports changes in site characterization planning from the baselined program outlined in the SCP.
The PR is not the mechanism for controlling changes to the SCP's technical baseline, it is intended only to report when a change has been made.

When OCRWM reorganized in November 1990, the responsibility for producing and distributing the $\mathrm{PR}$ was transferred to the Office of Geologic Disposal. As a result, distribution is taking place from the Yucca Mountain Site Characterization Project Office in

\section{EPA Presents Views on Legislation to Permit DOE Sife Characterization Without Obtaining State or Local Permits (Continued from page 2)}

"In light of this situation, EPA endorses Section 511 as the appropriate response. As we ask to support this provision, we want to assure the Committee that there will be no relaxation or minimization of enforcement of Federal environmental statutes and regulations which govern DOE's site characterization activities at Yucca Mountain. The Administration is committed to ensuring thatEPA has all of the necessary authority and capability to oversee DOE's activities and to ensure that such activities comply with both the letter and spirit of the federal law protecting human health and the environment. We also believe that this provision should not establish a precedent for future activities at Yucca Mountain or elsewhere. The Administration remains committed to State preeminence in administration and enforcement of environmental statutes." 


\section{Secrefary of Energy Wrifes to Readers of Las Vegas Newspaper}

On Mar. 22, 1991, the Review-Journal of Las Vegas, NV, published a letter to its readers from Secretary of Energy James D. Watkins. In his letter, Secretary Watkins stated:

"The National Energy Strategy introduced by the President in February represents more than two years of planning for a balanced approach to meet America's future energy needs. However, I am concerned that citizens of Nevada may have been deliberately misled by reports and statements that Nevada may have no more oversight authority for Yucca Mountain if the National Energy Strategy becomes law. This is simply wrong.

"The State of Nevada has already spent more than $\$ 40$ million in Federal funding for oversight activities connected with the Department of Energy's Yucca Mountain program, and will continue to receive funding in the future. The Department of Energy welcomes Nevada's scientists to oversee the conduct and evaluation of all phases of this complex geotechnical research project.
“The National Energy Strategy's proposal for Yucca Mountain deals with the narrow issue of which agency would review environmental permits. Like any other construction project in Nevada that disturbs the surface of the land, the Department of Energy must comply with Federal and State requirements that apply to air quality, water usage and other environmental considerations. As a consequence, the Department of Energy will, under any circumstance, fully comply with Federal and State environmental requirements. Nevada, to date, has refused even to process the necessary permits.

"Yet, the Department of Energy is required by law to completean exhaustive series of studies to determine whether Yucca Mountain is a suitable site to isolate high-level radioactive waste from the environment. In fact, the 1987 amendments to the Nuclear Waste Policy Act make it very clear: 'The Department of Energy must determine the suitability of Yucca Mountain before Congress will consider alternatives.'
"The National Energy Strategy proposal only allows the permitting process to go forward without the burden of endless litigation. The safety and health of workers, the citizens of Nevada, and protection of the environment will continue as our highest priority during the entire scope of the Yucca Mountain project.

"I have repeatedly asked for cooperation from Nevada's elected leaders and regulatory agencies. Had State officials been willing to consider options to proceed, we would not now be at the brink of congressional intervention.

"The time has come to begin the important research work at Yucca Mountain. If itrequires the designation of a Federal instead of a State agency to allow the Department of Energy to comply with all State and Federal environmental requirements, then this is a course of action I must urge Congress to endorse.
Financial statements from OCRWM's Seventh Annual

$$
\text { Report }
$$

In the preyouous lssue of the OCRWM Bullêtin, audited financial statements for Eiscal Years 1988 and 1989 were publistied Although the auditors report fơ Fiscal Year 1990 was not avaliabte for nolusiontin the Seventh Annual Report ${ }^{2}$ the unandted financial data were inclưded in the reportandare shown on pages 7 and 8 . The audited financial statements will be included in the nex annuat repont

\section{Secrefary of Energy Advisory Board Task Force on Civilian Radioactive Waste Management}

First Meefing Held by the

(Continued on page 5)
The Department of Energy recognizes that the resolution of outstanding institutional issues is as critical to the ultimate success of the civilian radioactive waste management program as the resolution of outstanding technical issues. No institutional issue commands as much attention and is as widely regarded and far reaching as the question of public trust and confidence.

The objective of the Secretary of Energy Advisory Board Task Force on Civilian Radioactive Waste Management, which held its first meeting on May 14, 1991, is to suggest approaches for establishing public trustworthiness so as to facilitate progress toward the Department's achieving its statutory obligations. Among the questions that the Task Force will consider are:

\section{The Meaning and Development of Public Trust and Confidence}

- Whose trust and confidence is most critical? Why?

- What are the most important factors affecting the level of public trust and confidence in the program?

(Continued on page 5) 


\section{First Meefing Held by the Secretary of Energy Advisory Board Task Force on Civilian Radioacfive Waste Management}

\section{(Continued from page 4)}

- What lessons has the program leamed from the past? What can be done to build on past successes and avoid past failures?

\section{Opportunities for Ensuring Public Trust and Confidence}

- How can the challenges that tend to make public trust and confidence in the radioactive waste management program problematic be addressed?

- Under what circumstances, if any, can alternative financial, organizational, and regulatory arrangements for the program promote public trust and confidence?

- Can the organizational structures and processes adopted for similar programs in other nations provide models for increasing the perceived trustworthiness of the U.S. program?

Consequences of Ensuring Public Trust and Confidence

- To what degree would additional efforts to foster public trust and confidence disrupt established program routines and organizational interactions?

- How would efforts to ensure high levels of public trust and confidence influence the timeliness and the cost of the radioactive waste management program?

- To what extent would initiatives to increase public trust and confidence affect or be affected by the regulatory regime for developing and licensing a repository?

When the Task Force has assessed alternative approaches for ensuring public trust and confidence, and has considered in general terms what the central advantages and disadvantages of each might be, it anticipates presenting its recommendations to the Secretary of Energy. These recommendations would also include guidance on whatsteps can be taken to implement them.
Members of the Task Force include:

Dr. William Bishop

Vice President

Desert Research Institute

Las Vegas, NV 89120

Mr. William Eichbaum

Vice President

Resources for the Future

Washington, DC 20037

Mr. Robert Fri

President

Resources for the Future

Washington, DC 20036

Ms. Kristine Gebbie

Secretary of Health

State of Washington

Olympia, WA 98504

Dr. John Landis

Senior Vice President

Stone and Webster Engineering Corp.

Boston, MA 94720

Dr. Todd La Porte, Chair

Professor, Political Science

University of Califomia

Berkeley, CA 94720

Dr. David Lester

Executive Director

Council of Energy Resource Tribes

Denver, CO 80202

Dr. Alfred Schneider

Professor, Nuclear Engineering

Georgia Institute of Technology

Atlanta, GA 30338

Mr. Mason Willrich

Chief Executive Officer

PG\&E Enterprises

San Francisco, CA 94106

Mr. Michael Wilson

Member

Florida Public Service Commission

Tallahassee, FL 32399
Dr. Mayer Zald

Professor of Sociology and

Social Work

University of Michigan

Ann Arbor, MI 48019

For further information on the Task Force, contact Dr. Daniel Metlay, Director, Secretary of Energy Advisory Board Task Force on Civilian Radioactive Waste Management, U.S. Department of Energy, AC-1, Washington, DC 20585, or call (202) 586-3903.

\section{Secrefary of Energy Writes to Readers of Las Vegas Newspaper (Continued from page 4)}

"This process of evaluation cannot be done by snap judgments, press releases or scientists debating theories. It can only be accomplished through years of thorough, painstaking tests of the mountain itself. Numerous independent scientists, including those employed by Nevada, are involved in fully reviewing the order and methods for conducting the scientific studies. Independent oversight groups such as the National Academy of Sciences and the Nuclear Waste Technical Review Board will join Nevada's scientists and those employed by the Department of Energy in analyzing the data from the studies. Only then will it become clear whether the site is suitable.

"Some Nevadans already feel convinced that Yucca Mountain is unsuitable for isolating high-level radioactive waste. It is surely, therefore, in their best interest to allow the scientific studies to proceed as a means to confirm their beliefs. A scientific determination of the suitability of Yucca Mountain is also vitally important to the Department of Energy, since we are required to carry out the mandate of Congress." 


\section{Nuclear Waste Technical Review Board Releases Its Third Report to the U.S. Congress and the U.S. Secrefary of Energy}

The Nuclear Waste Technical Review Board (the Board), as part of its congressional mandate to provide an independent review of the DOE program to manage the disposal of the Nation's high-level radioactive waste, has released its Third Report to the U.S. Congress and the U.S. Secretary of Energy. The Board makes 15 recommendations on technical aspects of DOE's program, which includes evaluating a site at Yucca Mountain, NV, as a possible location for a repository for the permanent disposal of spent fuel and high-level radioactive waste. The report also outlines the Board's future plans and reviews observations the Board made during its visit to research sites in Sweden and the Federal Republic of Germany in June 1990. The Third Report primarily covers Board activities from Aug. 1, 1990, to Jan. 31, 1991.
The report recommends that DOE reexamine its test plans to ensure an adequate evaluation of the saturated zone of the Yucca Mountain candidate site, which was determined in recent DOE studies to contribute to long-term waste isolation. The Board also recommends assigning higher priority to studies on developing a more robust engineered barrier system (EBS). The Board believes that much of the research on developing an EBS can be carried out simultaneously with sitecharacterization activities.

Other recommendations include seeking clarification of some regulations from the Nuclear Regulatory Commission, scheduling a workshop on ways to minimize handling of waste during the management cycle, improving the quality assurance grading process, and addressing the applicability of laboratory measurements in geochemistry and hydrology to site characterization.

Also included in the Board's Third Report is the Department of Energy's response to recommendations made in the Board's Second Report of November 1990. The responses address the seven broad areas of the Board's recommendations.

The Board's Third Report (Stock No. $061-000-00762-8$ ) is available for $\$ 5.50$ from the Superintendent of Documents, Government Printing Office, Washington, DC 20402; (202) 783-3238 Purchases can be made by check, money order, Visa or MasterCard.

\section{DOE Issues Draft Acceptance Priority Ranking}

The Standard Contract for Disposal of Spent Nuclear Fuel and/or High-Level Radioactive Waste requires that DOE issue an Acceptance Priority Ranking (APR) beginning on Apr. 1, 1991. The APR details the order in which DOE will allocate Federal acceptance capacity to the owners and generators (Purchasers) of spent nuclear fuel. As required by the Contract, the priority ranking is based on the age of permanently discharged fuel with owners of the oldest spent nuclear fuel given the highest priority.

The publication of the APR begins the formal waste acceptance process. Since the APR will become the basis for allocating waste acceptance capacity, as well as for approving Delivery Commitment Schedules, DOE is offering, until July 1, 1991, the Purchasers a final opportunity to verify the accuracy of the information in the rankings, by issuing a Draft APR prior to issuance of the first annual APR. The first annual APR will be issued after July 1,1991 , and will incorporate Purchaser comments.

Although DOE has previously indicated that the 1990 issue of the Annual Capacity Report (ACR) would be the final issue published, (see $O C R W M$ Bulletin, February/March 1991), DOE has elected to continue publication of the ACR for planning purposes. The ACR will use the APR as the basis for the allocation of waste acceptance capacity to the Purchasers.

For further information, contact Alan Brownstein at the Department of Energy, OCRWM, RW-43, 1000 Independence Avenue, S.W., Washington, DC 20585 or (202) 586-4973. 
NUCLEAR WASTE FUND

OFFICE OF CIVILIAN RADIOACTIVE WASTE MANAGEMENT UNITED STATES DEPARTMENT OF ENERGY

\section{Balance Sheets}

September 30,1990 and 1989

(Dollars in thousands)

Assets

Cash

U.S. Treasury securities

Receivables from utilities:

One-time spent fuel fees

KWH fees

Interest on one-time spent fuel fees

Receivable from Department of Energy for defense

high-level waste disposal costs

Accrued interest on U.S. Treasury securities

Other receivables and advances

Capital equipment, less accumulated depreciation of $\$ 24,209$ in 1990 and $\$ 20,109$ in 1989

Total Assets

Liabilities

Accounts payable and accrued expenses

Estimated payable to utilities on overpayment of KWH fees

Deferred revenue

Total Liabilities

\begin{tabular}{|c|c|}
\hline $\begin{array}{c}\text { (Unaudited) } \\
1990 \\
\end{array}$ & 1989 \\
\hline $\begin{array}{r}2,489 \\
2,630,169\end{array}$ & $\begin{array}{r}1,196 \\
2,248,544\end{array}$ \\
\hline $\begin{array}{r}896,875 \\
131,600 \\
685,707 \\
1,714,182\end{array}$ & $\begin{array}{r}899,659 \\
130,100 \\
567,447 \\
1,597,206\end{array}$ \\
\hline
\end{tabular}

\begin{tabular}{rr}
92,264 & $-72,197$ \\
586 & 1,325 \\
31,238 & 31,713 \\
\hline$\underline{4,470,928}$ & $\underline{3,952,181}$ \\
\hline
\end{tabular}

$31,352 \quad 67,508$

$280,000 \quad 200,000$

$4,159,576 \quad 3,684,673$

$\overline{4,470,928} \quad \overline{3,952,181}$ 
NUCLEAR WASTE FUND

OFFICE OF CIVILIAN RADIOACTIVE WASTE MANAGEMENT UNITED STATES DEPARTMENT OF ENERGY

\section{Statements of Operations}

Years ended September 30, 1990 and 1989

and cumulatively from January 7,1983 , date of inception

to September 30,1990

(Dollars in thousands)

\begin{tabular}{|c|c|c|c|}
\hline & $\begin{array}{c}\text { (Unaudited) } \\
1990\end{array}$ & 1989 & $\begin{array}{l}\text { (Unaudited) } \\
\text { Cumulative }\end{array}$ \\
\hline \multicolumn{4}{|l|}{ Revenue: } \\
\hline \multicolumn{4}{|l|}{ Fees: } \\
\hline One-time spent fuel fees & - & - & $2,334,777$ \\
\hline KWH fees & 551,512 & 317,186 & $3,060,047$ \\
\hline \multicolumn{4}{|l|}{ Interest: } \\
\hline One-time spent fuel fees & 121,503 & 116,490 & 704,718 \\
\hline U.S. Treasury securities & 199,428 & 169,304 & 808,125 \\
\hline \multicolumn{3}{|c|}{ Gain (loss) on sale of U.S. Treasury } & 32,198 \\
\hline & 872,460 & 602,848 & $6,939,865$ \\
\hline \multirow[t]{2}{*}{ Less amount deferred } & $(474,903)$ & $(227,289)$ & $(4,159,576)$ \\
\hline & 397,557 & $\mathbf{3 7 5 , 5 5 9}$ & $2,780,289$ \\
\hline \multicolumn{4}{|l|}{ Expenses: } \\
\hline First repọsitory & 203,304 & 237,306 & $1,964,922$ \\
\hline Second repository & 249 & 989 & 108,859 \\
\hline Monitored retrievable storage & 2,109 & 1,567 & 41,875 \\
\hline \multicolumn{4}{|l|}{ Transportation and systems } \\
\hline integration & 39,875 & 38,269 & 156,255 \\
\hline Program management & 61,191 & 93,395 & 395,553 \\
\hline Interest & 60,000 & 45 & 78,008 \\
\hline \multirow[t]{2}{*}{ Transfer appropriations } & 30,829 & 3,988 & 34,817 \\
\hline & 397,557 & 375,559 & $2,780,289$ \\
\hline Excess of revenue over expenses & 一 & - & $r$ \\
\hline
\end{tabular}




\section{Selected Events Calendar}

July 15 Nuclear Waste Technical Review Board, Structural Geology and Geoengineering Panel, Stouffer Concourse Hotel, Alexandria, VA. Contact Paula Alford at (703) 235-4473.

July 16-17 Nuclear Waste Technical Review Board, Full Board Meeting, StoufferConcourse Hotel, Alexandria, VA. Contact Karyn Severson at (703) 235-4473.

July 17-18 - Licensing Support Systems Advisory Review Panel Mceting, East-West Towers, Bethesda, MD. Contact Marilee Rood at (301) 492-4030.

July 24-26 Nuclear Regulatory Commission, Advisory Committee on Nuclear Waste Meeting, Bethesda, MD. Contact Barbara Jo White at (301) 492-7288.

August 11 National Conference of State Legislatures Annual Meeting, Orlando, FL. Contact NCSL Meetings Office at (202) 624-5400.

August $15 \quad$ Nuclear Waste Technical Review Board, Transportation and Systems Panel Public Hearing on Transportation Issues, Denver, CO. Contact Paula Alford at (703) 235-4473.

August 28-29 Nuclear Regulatory Commission, Advisory Committee on Nuclear Waste Meeting, Bethesda, MD. Contact Barbara Jo White at (301) 492-7288.

For details on DOE/NRC meetings call (1/800) 368-2235 for a recorded message. In the Washington, DC, area call 479-0487. A telephone recording service has been established for the announcement of upcoming meetings related to the waste management program of the NRC. The number is (1/800) 368-5642, ext. 20436. Washington, DC, area residents should call 492-0436.

For information on meetings and events occurring between issues of the OCRWM Bulletin use OCRWM INFOLINK, a computerized data base containing information about the OCRWM program. The OCRWM Bulletin is also available online through INFOLINK.

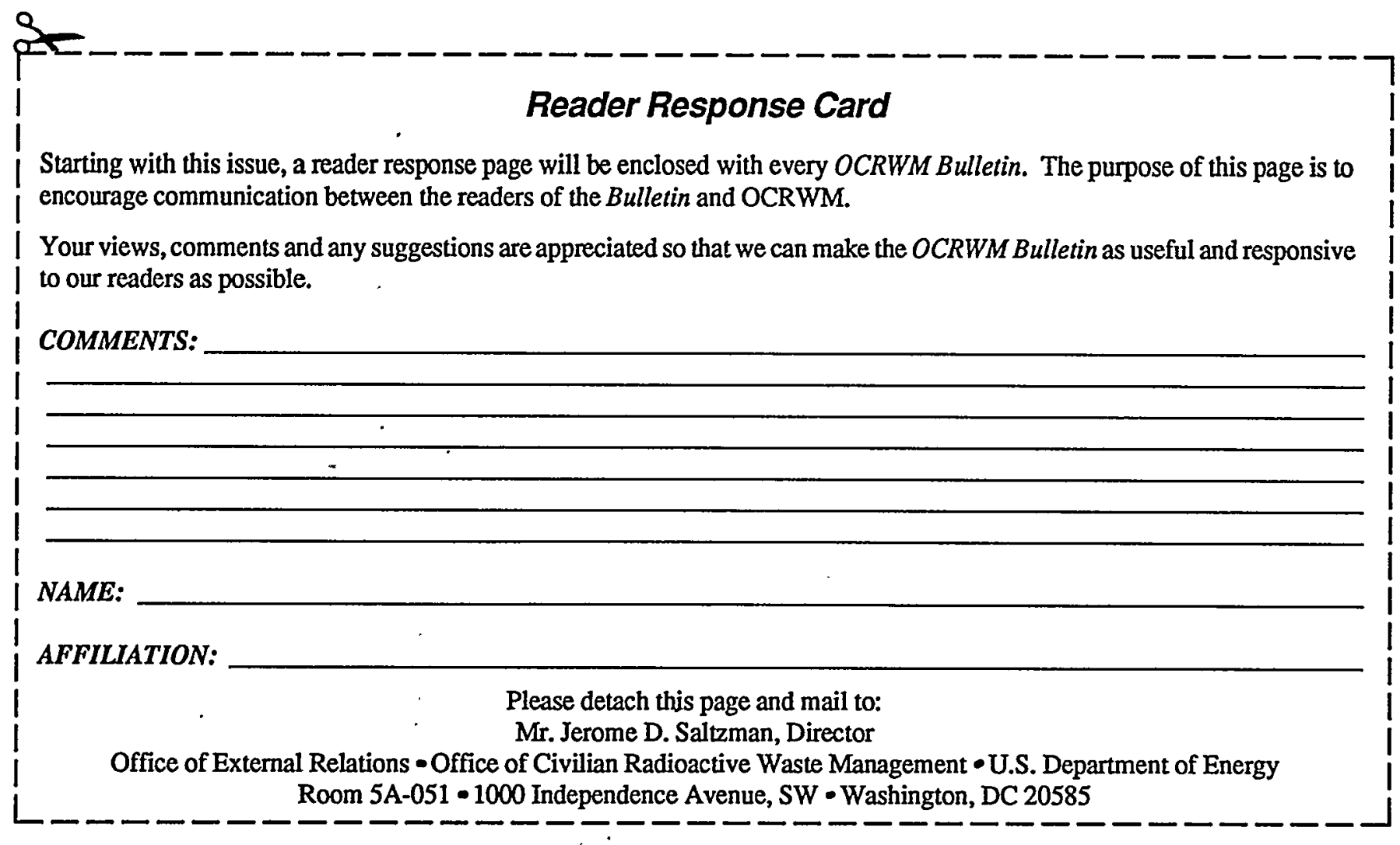




\section{OCRWM Bulletin}

United States Department Of Energy • Office Of Civilian

Radioactive Waste Management

Washington, DC 20585

July/August 1991

\section{DOE Initiates New Site Characterization Studies At Yucca Mountain}

As part of an overall site characterization program to determine if Yucca Mountain, Nevada, is a suitable, safe place for a high-level nuclear waste repository, DOE began new surface-disturbing activities in July 1991. These activities were started after the State of Nevada issued an air quality permit on June 12, 1991 (see OCRWM Bulletin, April 1991 and May/June 1991 for discussions of litigation relating to the issuance of permits).

The types of investigations to be undertaken at Yucca Mountain include geology, volcanology, hydrology, tectonics, and geoengineering studies. They will be conducted through a series of drill holes, trenches, geophysical surveys, monitoring stations, and laboratory work. The investigations undertaken in July at the Yucca Mountain site involve trenching work at Midway Valley and Trench 14, and volcanism studies at Crater Flat.

\section{Midway Valley}

The nature of potential faulting and surface materials will be investigated in Midway Valley, the candidate site for potential repository surface facilities. The activities begun in Midway Valley in July included the excavation and mapping of exploratory trenches.

The data from the trenches will be used to help characterize the magnitude and history of past movements on faults throughout the site area that may have been active within the last $2,000,000$ years. An additional objective is to investigate the minerals found in these fault zones.

Seismic hazard studies are being done to ensure that, should the repository be sited at Yucca Mountain, facilities on the surface and underground would not be disturbed by cracks and movement of the rock. At the present, it appears that the risk of damage to underground facilities from earthquakes is small.

\section{Trench 14}

In the early 1980 s, trenches were excavated across the Bow Ridge Fault. The already existing Trench 14 will be deepened to at least twice its current depth of 10 to 12 feet in order to gain more evidence on the origin of the calcite/silica deposits found in the trench. The vein-like deposits of calcite and silica extending to the floor of the trench (see photograph on page 2) have been the subject of considerable scientific debate. The issues of this debate are currently under review by two separate peer review panels -one consisting of 17 members of the $\mathrm{Na}$ tional Academy of Sciences and the other comprising a panel whose 5 members were chosen by proponents of 2 different views.

The debate concerns the origin of the water responsible for depositing the minerals in the veins. Most scientists believe the deposits were formed by downward percolating rain- water that dissolves carbonate minerals and silica as it moves through the soils and redeposits them when the waters evaporate at lower levels. A small number of scientists have asserted that the minerals represent ancient spring deposits and therefore indicate that a water table has been at the current surface in the past. DOE believes it is

Continued on page 3

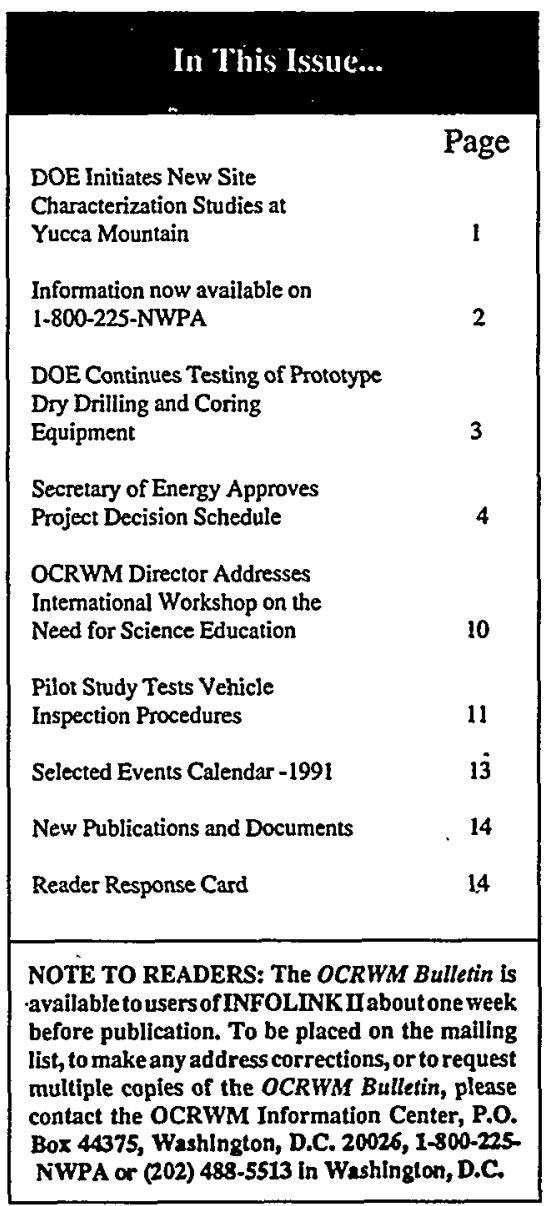

Published by the U.S. Department of Energy (DOE), Office of Civilian Radioactive Waste Management (OCRWM)

For further information about the national program or for copies of new OCRWM publications and documents listed in the OCRWM Bulletin, contact the U.S. Department of Energy, OCRWM, Office of External Relations, Education and Information Division, Mail Stop RW-5.1, 1000 Independence Avenue, S.W., Washington, DC20585, (202) 586-5722 or the OCRWM Information Center, P,O. Box 44375, Washington, D.C. 20026, 1-800-225-NWPA or (202) 488-5513 in Washington, D.C. The OCRWM Information Services Directory is available to provide sources of program information. 


\section{Information Now Available On 1-800-225-NWPA}

In response to increased requests for information, OCRWM will activate an 800 number public information system. This system will provide a convenient, centralized mechanism for all interested parties -- from the general public to educators -- to obtain timely information about the Nation's high-level radioactive waste management program. Printed materials, including fact sheets, brochures, program publications, educational materials, and videotapes will be available to the caller.
The 800 number approach allows the public to access the most up-to-date information about the OCRWM program, and will be a valuable added resource for teachers as well as students studying issues of nuclear waste management.

OCRWM's Office of External Relations, Education and Information Division, will manage the 800 number system. The 800 number system will begin operation on September 16, 1991. This system can be ac- cessed by dialing 1-800-225-NWPA (6972), except in Washington, D.C., where callers may dial 488-5513. Written inquiries and comments may be directed to OCRWM Information Center, P.O. Box 44375, Washington, D.C. 20026. th

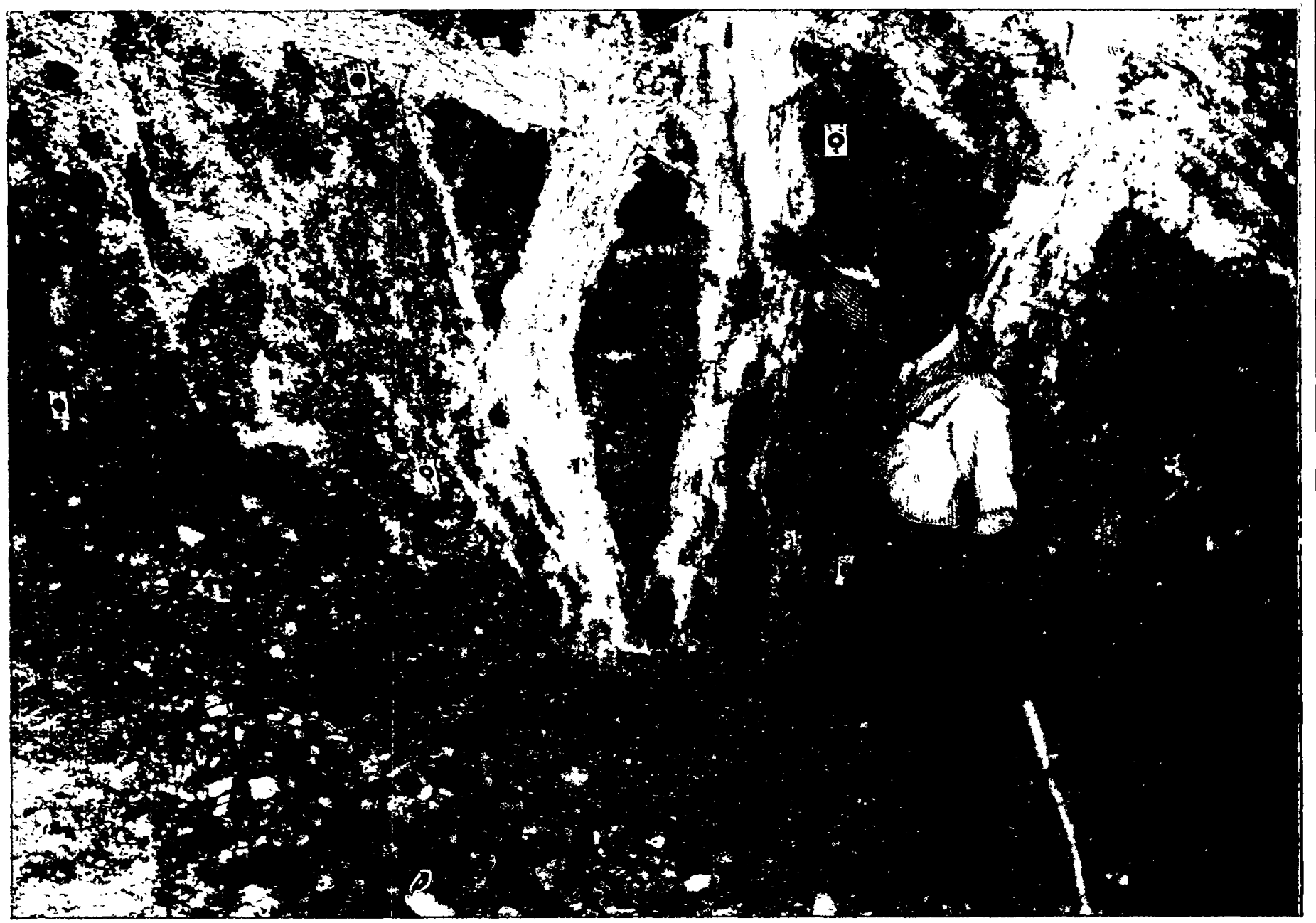

Carl Gertz, Project Manager of the Yucca Mountain Site Characterization Project, points to calcite and silica deposits (light-colored material) in Trench 14 before new trenching activities were undertaken. 


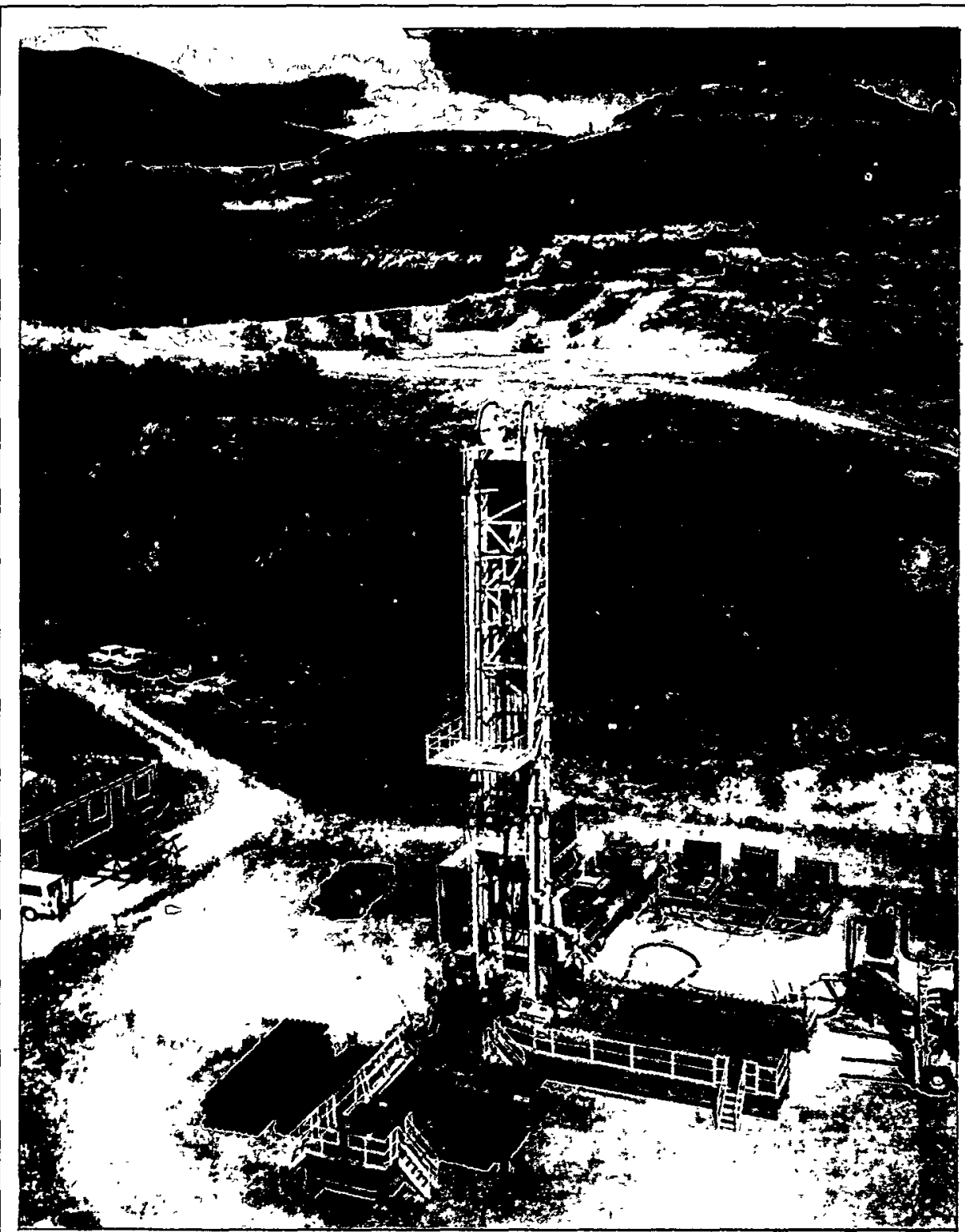

LM-300 Drill Rig with mast raised. This is the largest rig of this type in existence - with a capacity over 3 times greater than the largest' commercial rig.

\section{Continued from page 1}

important to study and understand the evidence of past hydrologic conditions at the site because credible release mechanisms for a repository involve the dissolution and transport of radionuclides in ground water.

\section{Volcanism Studies}

At Crater Flat, small scale soil pits were dug during July near the Lathrop Wells cone. - This work is necessary to collect samples which will be used to further characterize certain volcanic features such as age, origin, and other features.
Volcanism studies during the past 10 years show that the last eruptions from one of 7 volcanic centers located about 12 miles from Yucca Mountain may have occurred less than 50,000 years ago. Project scientists think another eruption at this volcanic center would not affect the integrity of Yucca Mountain. However, more studies are planned to prove or disprove this conclusion.

Areas of study include examining the possibility of another volcanic eruption within 10,000 years at one of the younger volcanic centers or the formation of a new volcanic

\section{DOE Continues Testing of Prototype Dry Drilling And Coring Equipment}

Performance testing of prototype dry drilling and coring equipment is underway at the BarrickResources Corporation MercurGold Mine about 55 miles southwest of Salt Lake City, Utah. The purpose is to examine elements of the LM-300 Drill Rig and Pipe Handling System, designed and built specifically for DOE at an approximate cost of $\$ 4$ million, for application to future drilling and coring procedures in support of site characterization for the Yucca Mountain Site Characterization Project. The Yucca Mountain Project Office plans to use four of these rigs during site characterization activities.

The LM-300 drilling rig with its dual wall dry drilling and coring system is the key to acquiring scientific samples at depth for the unsaturated zone study program on Yucca Mountain. The overall objective of the current phase of the drill testing is to perform shakedown testing of the equipment on the prototype drill rig for verification of reliability.

The drill site in Utah was selected because of suitable geologic conditions and its close proximity to the manufacturing facility in case repairs might be needed. The rocks at the site are sedimentary, primarily massive bedded limestones with interbedded sandstone layers.

The 13-inch diameterborehole will be drilled to about 2,000 feet. Samples will be collected every five feet. Limited coring will be accomplished near the surface and at an intermediate depth, but most of the coring will be near and below 2,000 feet.

center. Project scientists now think the probability of a new volcanic center erupting at Yucca Mountain is extremely low.

战 


\section{Secretary Of Energy Approves Project Decision Schedule}

Section 114(e) of the Nuclear Waste Policy Act (NWPA) of 1982 requires that the Secretary of Energy issue and update, as necessary, a Project Decision Schedule (PDS). The purpose of the PDS is to portray the optimum way to attain operation of a geologic repository. The PDS contains a description of activities and deadlines for Federal agencies required to take action to achieve repository deadlines. It serves as a commitment by those agencies to the activities, attendant milestones, and deadlines for taking action in support of OCRWM's repository schedule.

The PDS issued in June 1991 constitutes the first revision of the PDS since the original document was issued in March 1986. Revision of the PDS was initiated following passage of the Nuclear Waste Policy Amendments Act of 1987 (NWPAA), but was delayed pending completion of the Secretary's reassessment of the Civilian Radioactive Waste Management Program and approval of a new Program Schedule Baseline (see OCRWM Bulletin, November/December 1989).

\section{Program Schedule for OCRWM}

The Federal agency activity schedules and milestones in the PDS are based on the OCRWM Program Schedule Baseline developed from the current supporting logic networks used in maintaining that baseline. Figure 1 (page 5) displays the current schedule baseline for development and operation of the waste management system. If significant changes in the schedule baseline are approved that affect PDS milestones for other Federal agencies, OCRWM will, after consultation with affected agencies, issue a revision or amendment to the PDS.

\section{Geologic Repository Site Nomination and Characterization Schedule}

OCRWM is currently in the site characterization phase of the repository project. The passage of the NWPAA designated the Yucca Mountain, Nevada, candidate site as the only site to be characterized. If the site is found to be unsuitable, DOE will terminate all site investigation activities and report to Congress, not later than 6 months aftersuch determination with the Secretary's recommendations for further action. The schedule for the geologic repository site nomination and site characterization phases taken from the PDS is shown in Figure 2 (page 6).

Assuming the scientific investigation process shows the Yucca Mountain candidate site to be suitable, and after approval and designation of the site, OCRWM will submit a license application for a repository to the Nuclear Regulatory Commission. Construction of the repository is scheduled to begin in 2004, which will allow OCRWM to begin accepting spent fuel at the repository in 2010. The schedule for the licensing review and construction phases in the PDS is shown in Figure 3 (page 7).

\section{Monitored Retrievable Storage Summary Schedule}

Schedules for the Monitored Retrievable Storage (MRS) facility (Figure 4, page 8) are included in the PDS to provide an overview of this component of the waste man- agement system. The reference schedule for the MRS facility assumes (1) a volunteer site will be obtained, and (2) the statutory schedule linkages between the MRS facility and the repository will be rescinded. Under these assumptions, it is estimated that waste acceptance at a simple receipt facility could begin, on a limited basis, as early as January 1998; a full capability MRS facility would be available in the year 1999 .

\section{Transportation Schedule}

The transportation system will move waste from designated points of origin and storage locations to the MRS facility and the repository. The schedule for the development of the transportation system has been coordinated with that of the waste management system as a whole, and therefore is to be ready to support MRS and repository operations. Currently, the development of the transportation system has a basic goal of establishing a limited capability to transport spent fuel by 1998 . Figure 5 (page 9) presents the schedule for the transportation system. is 


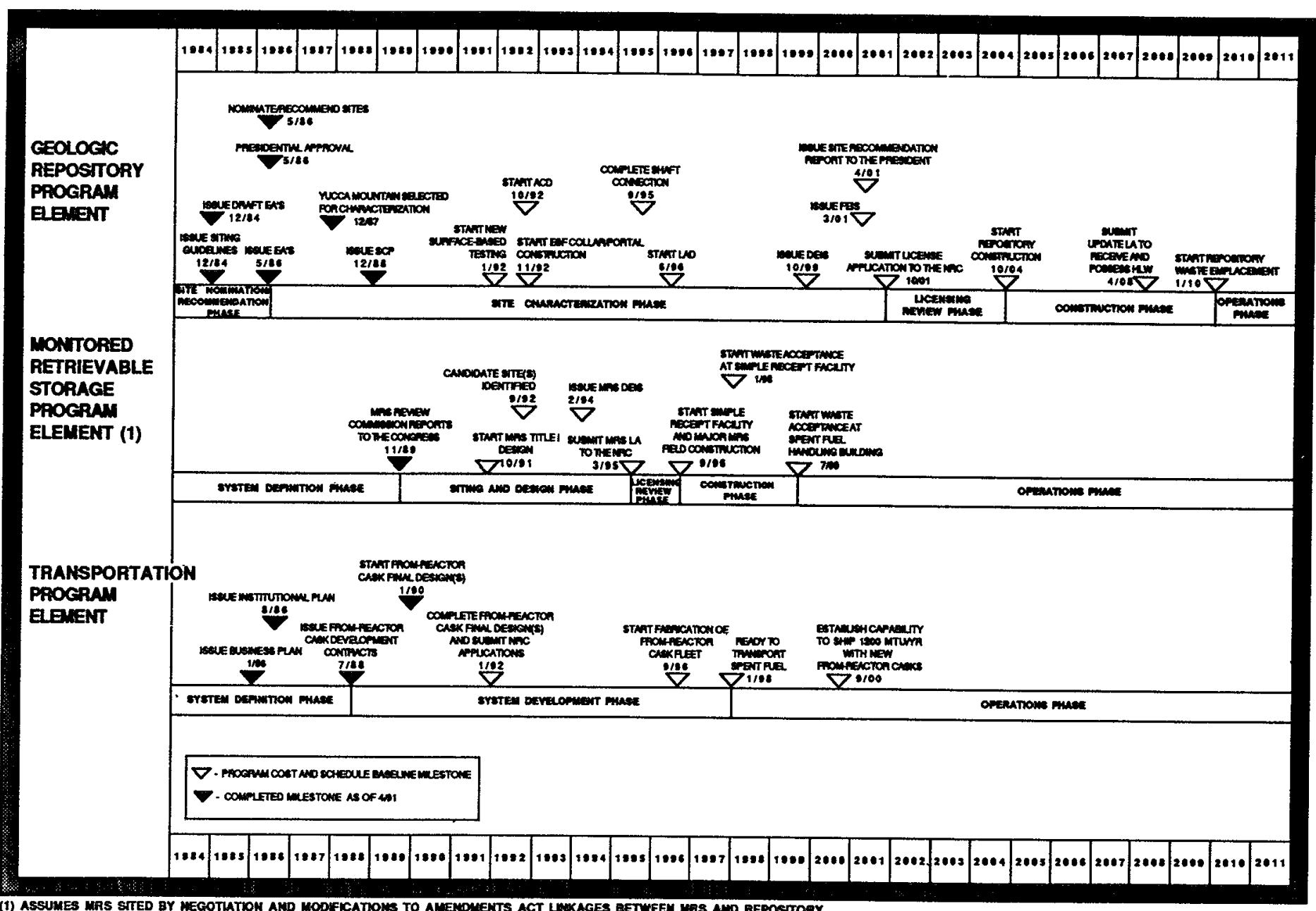

Figure 1

Office Of Civilian Radioactive Waste Management Program Schedule 


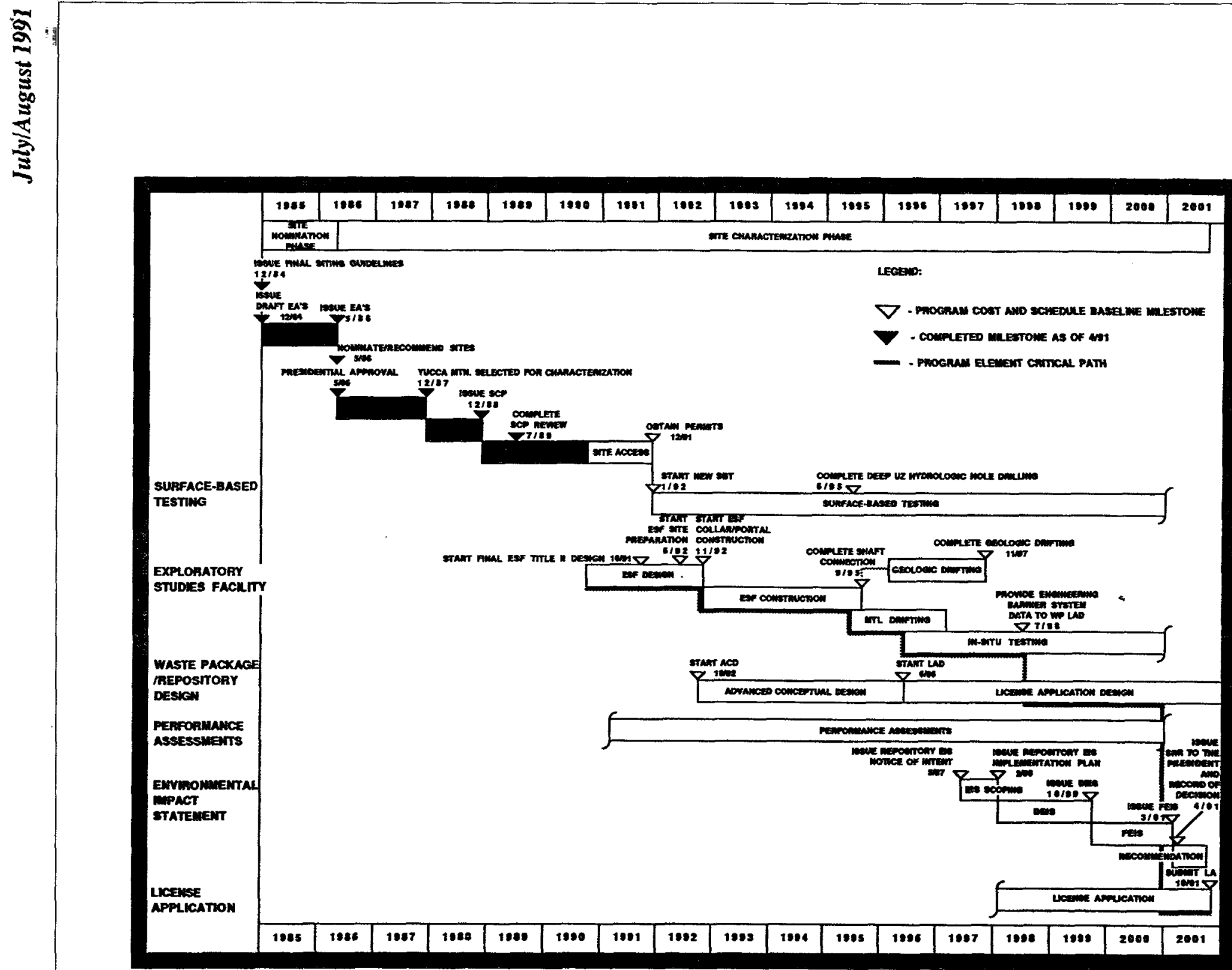

Figure 2

Geologic Repository Site Nomination And Characterization Phases 

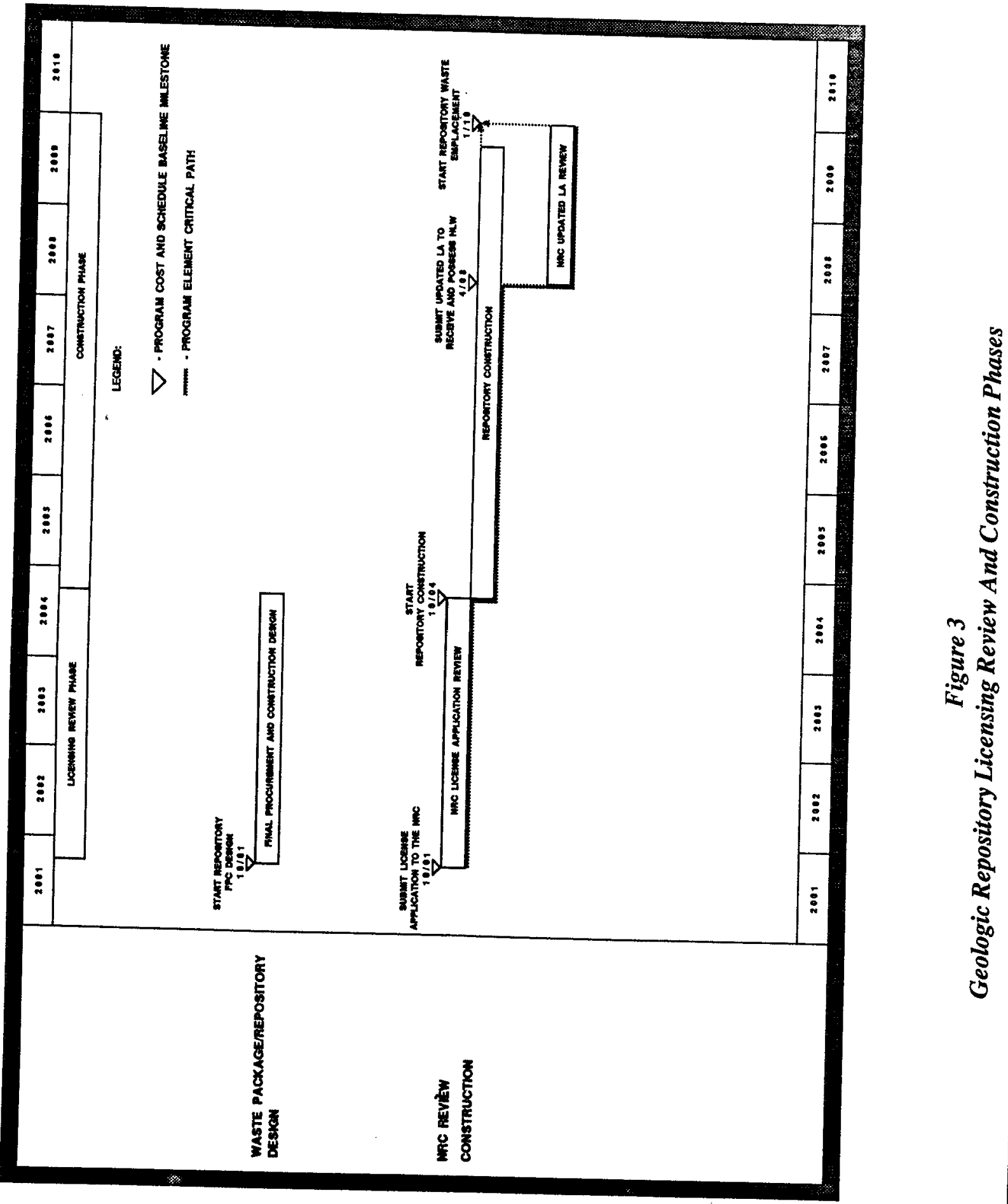


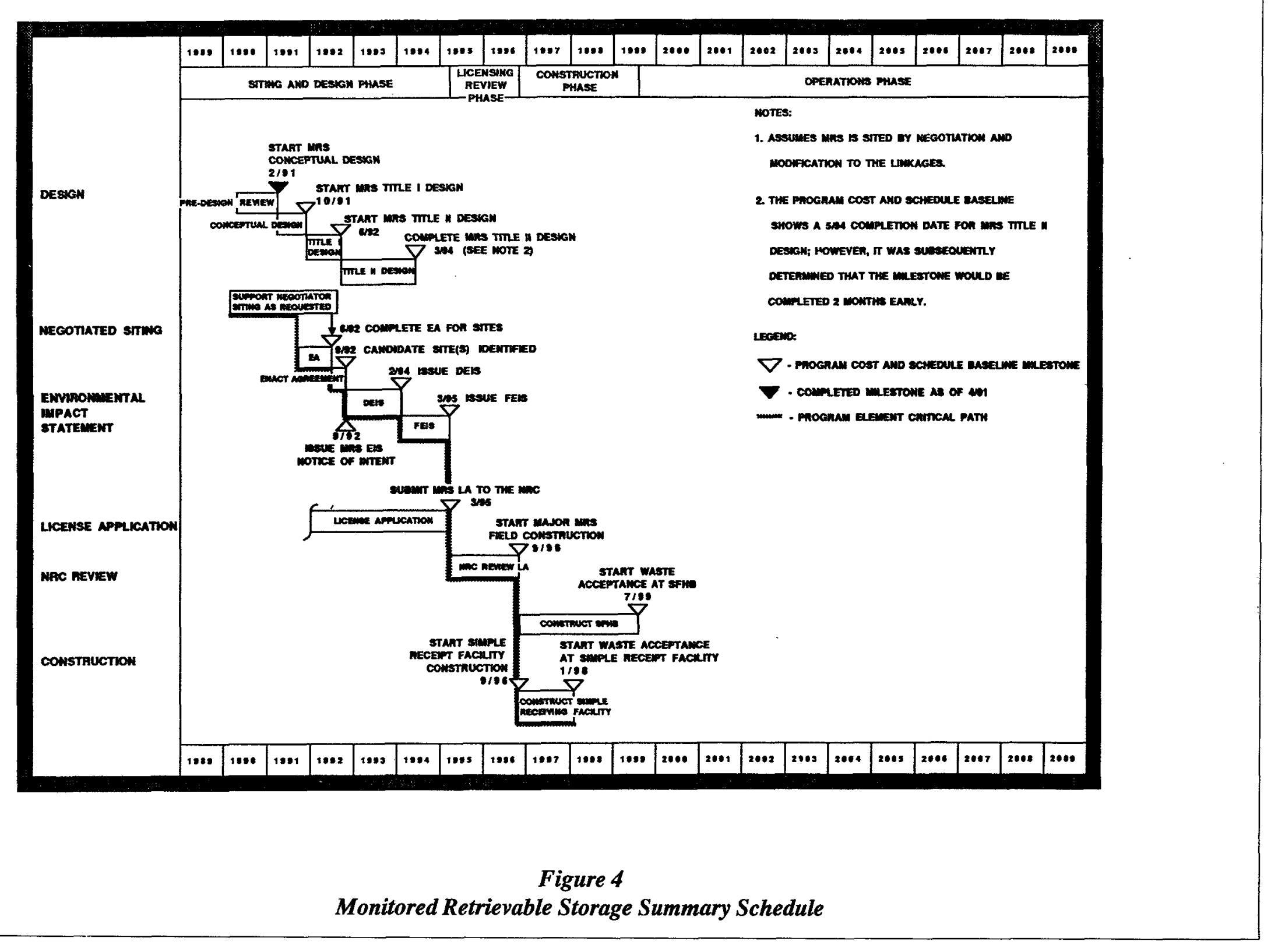




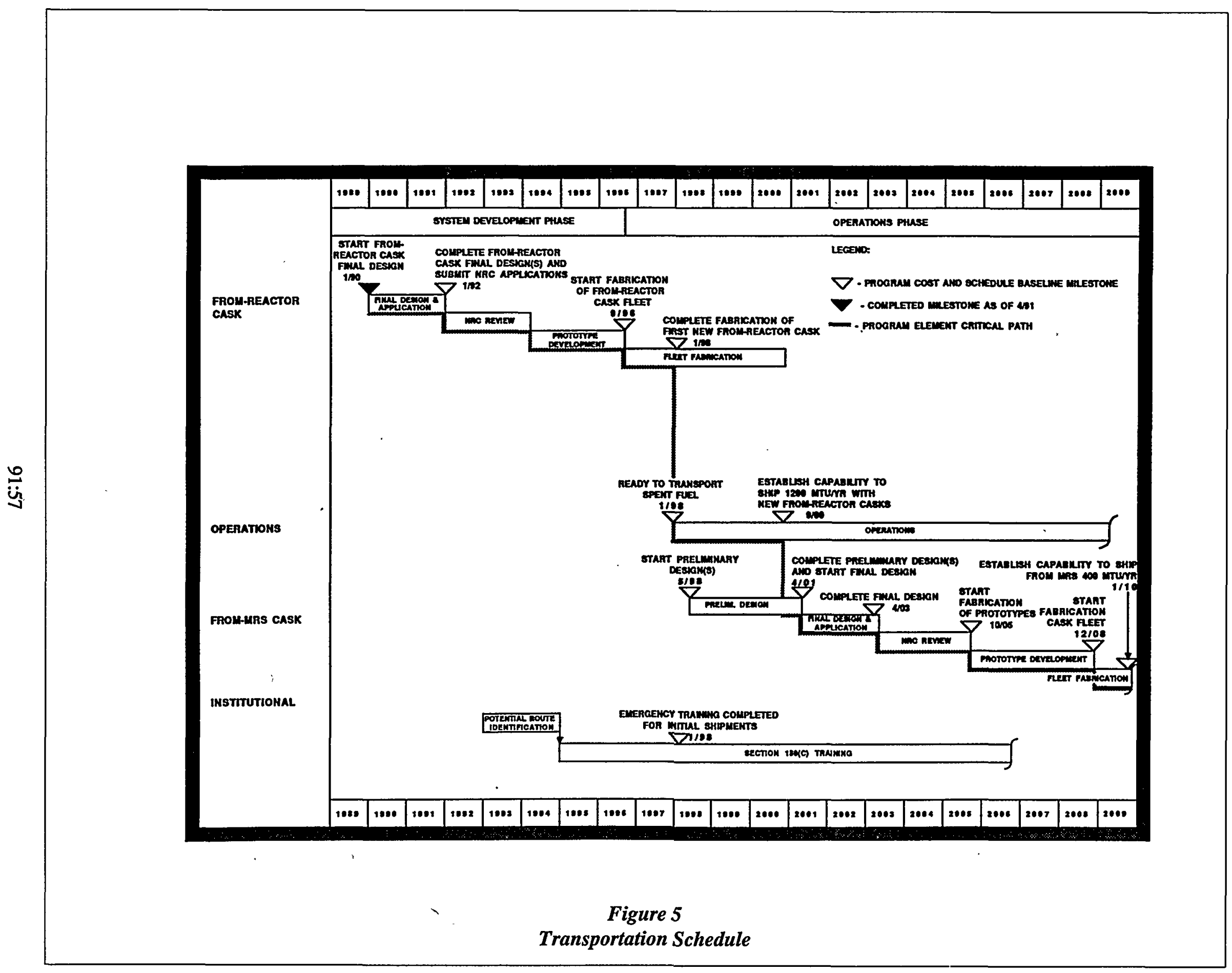




\section{OCRWM Director Addresses International Workshop On The Need For Science Education}

The first International Workshop on Education in the Field of Radioactive Waste Management was held on June 16-20, 1991, in Engelburg, Switzerland. Jointly organized by the Organization for Economic Cooperation and Development (OECD) Nuclear Energy Agency and DOE's Office of Civilian Radioactive Waste Management, in cooperation with the Swiss Cooperative for the Storage of Radioactive Waste (CEDRA) NAGRA), this international workshop was held to address the important issues relating to public education in the field of energy, science, and the environment.

The objectives of the workshop were to contribute to an information base for education systems on global aspects of radioactive waste management and to achieve an international consensus on the basic tools and methods required to develop this information base. All of the 12 OECD countries involved in this workshop are dealing with the serious problem of educating the public about nuclear energy in general and nuclear waste in particular. The workshop provided a better understanding of common educational needs to help nations develop curriculum and instruction in nuclear energy that meets the needs of contemporary society in the various countries.

Dr. John W. Bartlett, the Director of DOE's Office of Civilian Radioactive Waste Management and Mrs. Ginger King, Director of OCRWM's Education and Information Division, represented the U.S. waste management program at the International Workshop. Dr. Bartlett, who chaired the Workshop, addressed the opening session and spoke about the need for science education and science literacy and the importance of participation in the international education project. His remarks are excerpted below:

"As the Director of the U.S. program for high-level radioactive waste management, I have a great appreciation for the need for science education and science literacy in today's high tech society. In today's society throughout the world we face many problems of interface between science and society and between energy and the environment. Add to that modern communications systems, such as those which we recently watched on live television the War in the Gulf, and we not only increase our global awareness, but we also magnify global actions and issues.

"We all are impacted by what other nations do. We all are impacted by what we do collectively. The concerns of our respective citizens are the same. We all need energy and electricity production. We need to work together to identify and address the concerns of the public. We need to prepare the youth of today and future generations to make decisions concerning energy and protection of the environment. Exchanges and workshops such as this will contribute significantly to this challenge.

"Energy is a major component of OECD economies, both as an industrial sector in itself and as an essential input to most other economic activities, whether it be agriculture, industries, or services. Energy also plays an important role in everyday life, whether it be for heating or cooling houses or business establishments, supplying power for domestic services, or providing the capacity to travel to one's workplace and business or holiday activities. Energy plays an important economic and political role in the world context. But the locations of major energy resources, such as oil, gas, and coal fields, relative to the large consuming countries, give rise to complex relationships between producers and consumers. And, finally, energy is concerned by worldwide preoccupations with sustainable development and the "greenhouse effect," as well as energy security and economic growth.

"Consumption of total primary energy in the world is projected to grow steadily between now and 2010 spurred primarily by continued economic growth. As with economic growth, energy consumption is projected to grow most rapidly in the developing countries. Overall, the total energy requirements of OECD countries have increased by almost 30 percent over the past 20 years.
"Electricity generation continues to grow. There are now more than 430 nuclear reactors operating in the world in 25 countries and another 100 under construction. Worldwide, these nuclear reactors provide more than 17 percent of the world's electricity; approximately 80 percent of the world's nuclear-generated electricity is produced by OECD countries. Three countries produce more than 50 percent of their electricity from nuclear power -- France (more than 75 percent), Belgium (more than 60 percent), and South Korea (more than 50 percent).

"But prospects for nuclear power vary considerably among even OECD countries. Several European countries are scaling back on plans for future nuclear power development due to concerns about nuclear plant safety and waste disposal. The problems concerning nuclear power center around three main issues: its low level of public acceptance -- particularly since the Chernobyl accident; its economics, especially in the context of low fossil fuel prices; and its own unique environmental problems, the most important of which being the disposal of radioactive waste.

"What is lost in this discussion, however, is the lack of understanding among the publics of our nations of the environmental advantages and disadvantages of each energy source and the consensus among our nations of the solutions for radioactive waste management and disposal.

"Clearly, a key to greater public confidence in radioactive waste management, electricity generation needs, and public consensus is through long-term education by means of global focus and projects that contribute both to greater scientific literacy and increased overall understanding.

"This workshop is a giant step toward education by building an information base and network for education systems between and among our nations on the global aspects of radioactive waste management. This workshop and the subsequent workshops and 


\section{Pilot Study Tests Vehicle Inspection Procedures}

In 1986, OCRWM entered into a cooperative agreement with the Commercial Vehicle Safety Alliance (CVSA) for CVSA to evaluate the vehicle inspection needs of the States, and to develop a model standard for the inspection of highway shipments of spent nuclear fuel and high-level radioactive waste. The CVSA is an association of State and Provincial officials in the United States and Canada who are responsible for the administration and enforcement of motor carrier safety laws for any commercial and hazardous materials shipments within their respective jurisdictions. The CVSA developed the highway inspection procedures known as the North American Standard.

Under its OCRWM cooperative agreement, CVSA developed national draft State in- spection procedures for the transport of spent nuclear fuel and high-level radioactive waste by commercial highway vehicles. Minimum performance standards included inspection procedures for drivers, shipping papers, vehicles, and packages. The Conference of Radiation Control Program Directors, also under cooperative agreement with OCRWM, drafted the radiological inspection procedures incorporated into the CVSA inspection procedures.

With input from cooperative groups, utilities, Waste Isolation Pilot Project (WIPP) and OCRWM Transportation Program personnel, a pilot study was created in 1989 to comprehensively test the procedures (see illustrations on page 12). DOE's WIPP Office has agreed to provide the study a

\section{Continued from page 10}

education programs, which I hope will result from this workshop, will contribute to building the knowledge bases of the sciences and environmental fields required for our citizens to make informed decisions required at the crossroads of energy, science, and the environment.

"As an educator, a scientist, and a global citizen, I have come to realize that science and technology address the problems and provide the solutions, but science and technology do not in themselves ensure that the solutions will be accepted and implemented. It takes society and societal decisions, awareness, and acceptance to decide which solutions to accept and which solutions to implement.

"The objectives of this International Workshop on Education in the Field of Radioactive Waste Management are:

- To contribute to an information base for education systems, on global aspects of radioactive waste management; and

- To achieve an international consensus on the basic tools and methods required to develop this information base.
"This workshop was conceived as a result of information exchanges and collaborative efforts of an informal OECD/NEA Radioactive Waste Public Information Working Group that was established in 1987. The purpose of the Working Group is to exchange information on effective public information programs, to recognize'public concerns and exchange lessons learned, and to provide support and resources among member countries.

"The safe management of radioactive waste is an integral part of the responsibilities of all modern societies with nuclear power, as well as those without nuclear power. Teaching younger and future generations on this subject is an importantelementof energy, science, and environmental education.

"I encourage each of you to learn from each other; to help develop a higher awareness of the global aspects of energy, science, and the environment as it relates to radioactive waste management; and to then take home and use your increased knowledge to expand the knowledge of our young.

$$
\text { 约 }
$$

sample of waste shipments from the Idaho National Engineering Laboratory, Idaho, to the WIPP in Carlsbad, New Mexico. State inspectors will be trained to use the proposed procedures and to supply research data for the pilot test. The Western Governors' Association, under its agreement with DOE's WIPP Office, monitors developments and participates in the planning process. While the study plans to focus on WIPP shipments, other shipments of spent fuel and high-level radioactive waste may be included.

The pilot study is expected to validate CVSA's final inspection procedures and help establish a coordinated Federal/State system to ensure the safety of highway shipments of spent fuel and high-level radioactive waste. For more information, contact Gary Curtis, CVSA Project Manager, at (301) 553-6420 or Christopher A. Kouts, OCRWM Transportation Branch Chief, at (202) 586-9761.<smiles>[Y]1C[Al]1</smiles> 
CVSA Pilot Study Milestones

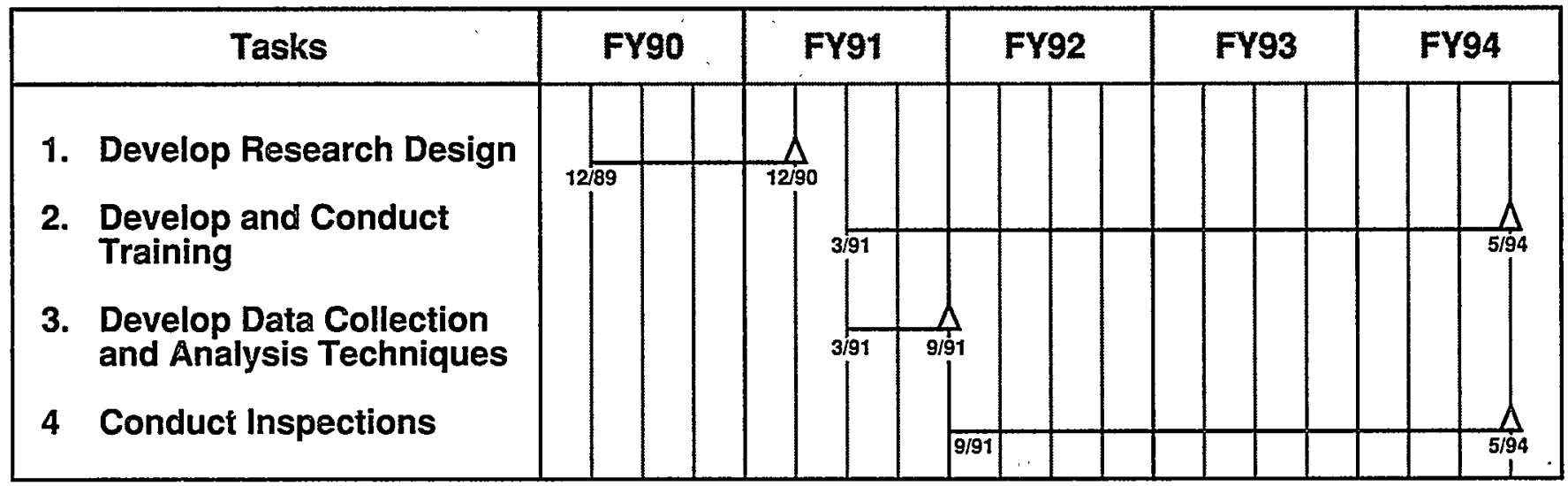

CVSA Pilot Study Participants

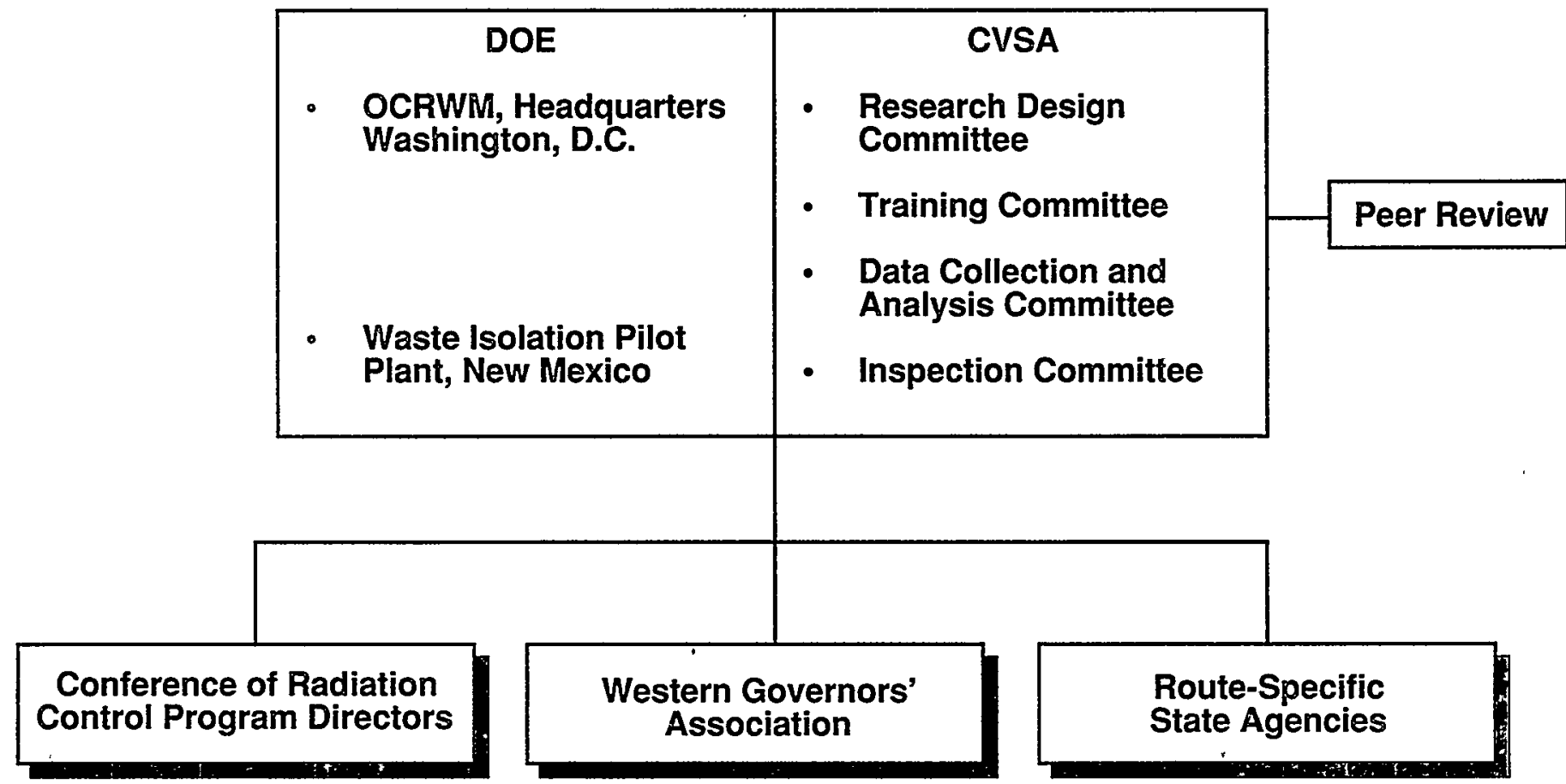




\section{Selected Events Calendar - 1991}

August 11

August 15

August 28-29

September 5-6

September 12

September 16-17

September 18-19

September 25-27

October 8-11

October 29-30

November 12-13

November 19
National Conference of State Legislatures Annual Meeting, Orlando, FL. Contact NCSL Meetings Office at (202) 624-5400.

Nuclear Waste Technical Review Board, Transportation and Systems Panel, Public Hearing on Transportation Issues, Denver, CO. Contact Paula Alford at (703) $235-4473$.

Nuclear Regulatory Commission, Advisory Committee on Nuclear Waste, Meeting, Bethesda, MD. Contact Barbara Jo White at (301) 492-7288.

Nuclear Waste Technical Review Board, Panel on Structural Geology and Geoengineering, Meeting on Seismic Risk, Salt Lake City, UT, Red Lion Hotel. Contact Paula Alford at (703) 235-4473.

DOE/Nuclear Regulatory Commission Meeting on Procedural Arrangements, location to be determined in the Washington, D.C. area. Contact Linda Desell at (202) 586-1462.

DOE/Nuclear Regulatory Commission Meeting on Exploratory Studies Facility/ Design Control, Las Vegas, NV. Contact Priscilla Bunton at (202) 586-9896.

Nuclear Waste Technical Review Board, Panel on Structural Geology and Geoengineering, Meeting on Exploratory Studies Facility Design Review, Las Vegas, NV, St. Tropez Hotel. Contact Paula Alford at (703) 235-4473.

Nuclear Waste Technical Review Board, Panel on Transportation and Systems, Meeting on DOE Update on Transportation Issues. Board Offices, 1100 Wilson Boulevard, Suite 910, Arlington, VA 22209. Contact Paula Alford at (703) 235-4473.

Nuclear Waste Technical Review Board, Full Board Meeting on Thermal Loading/Repository Design, Las Vegas, NV, St. Tropez Hotel. Contact Paula Alford at (703) 235-4473.

DOE/Nuclear Regulatory Commission Meeting on Scenario Development, location to be determined in Washington, D.C. area. Contact Priscilla Bunton at (202) 586-9896.

Nuclear Waste Technical Review Board, Panel on Structural Geology and Geoengineering, Meeting on Technology of Backfill, Sealing, and Openings; Exploratory Studies Facility Design Review. Seattle, WA, Wyndham Garden Hotel. Contact Paula Alford at (703) 235-4473.

DOE/Nuclear Regulatory Commission Meeting on Regulatory Strategy, location to be determined in Washington, D.C. area. Contact Linda Desell at (202) 586-1462. 


\section{New Publications And Documents}

Project Decision Schedule, Revision 1,DOE/RW-0310P, June 1991.

This is the first revision of the Project Decision Schedule (PDS) for the Civilian Radioactive Waste Management Program, replacing the original PDS issued in March 1986. Required by the NuclearWaste Policy Act of 1982, as amended, the PDS is to portray the optimum way to attain the operation of the repository. This document includes a description of objectives and a sequence of deadlines for all Federal agencies that are required to take action in achieving this goal. The activity deadlines included in this issue of the PDS are based on the Nuclear Waste Policy Amendments Act of 1987 and the Office of Civilian Radioactive Waste Management's Program Schedule Baseline.

\section{A Monitored Retrievable Storage} Facility: Technical Background Information, DOE/RW-0311P, July 1991.

This document presents an overview of various aspects of a monitored retrievable storage facility, including the process by which it will be developed. While each section of the document treats a different topic, some sections are closely interrelated, and cross references are provided where appropriate.

\section{色}

\section{Reader Response Card}

A reader response page is enclosed with every OCRWM Bulletin. The purpose of this page is to encourage communication between the readers of the Bulletin and OCRWM.

Your views, comments, and suggestions are appreciated so that we can make the OCRWM Bulletin as useful and responsive to our readers as possible.

\section{Comments:}

Name:

Address:

Affiliation:

Please detach this page and mail to: Mr. Jerome Saltzman, Director Office of External Relations - Office of Civilian Radioactive Waste Management -U.S. Department of Energy Mail Stop RW 5.1 •1000 Independence Avenue, SW $\bullet$ Washington, DC 20585 


\section{OCRWM Bulletin}

United States Department Of Energy • Office Of Civilian Radioactive Waste Management Washington, DC 20585

September/October 1991

\section{DOE Awards First MRS Grant To Mescalero Apache Tribe}

On October 18, 1991, DOE awarded its first grant to study the feasibility of siting an above-ground, monitored retrievable storage (MRS) facility for the temporary storage of commercial spent nuclear fuel. The grant for $\$ 100,000$ was awarded to the Mescalero Apache Tribe of Mescalero, New Mexico, and will be used by the Tribe to gain an understanding of the Nation's nuclear waste management system, including the MRS facility component, and to determine whether it has an interest in pursuing further feasibility studies.

In commenting on the grant award, Dr. John Bartlett, Director of OCRWM, said, "This award is an important step forward for the program and is the result of successful efforts by the Nuclear Waste Negotiator, David Leroy. We will respond to requests from the Mescalero Tribe for assistance in their evaluations as effectively as possible."
The MRS facility that will be studied would be an above-ground storage facility using proven technology to the maximum extent practicable. The facility would receive, temporarily store, and stage spent nuclear fuel for ultimate disposal in a permanent geologic repository. The MRS facility would be subject to licensing by the Nuclear Regulatory Commission and to applicable federal and State environmental, safety, and health regulations.

Grant applications for feasibility studies will be accepted until December 31, 1991. Requests for copies of the solicitation can be made in writing to the Department of Energy, Office of Placement and Administration, Attn: Ms. Kristin Wright/ PR-322.2, 1000 Independence Avenue, S.W., Washington, D.C. 20585, (202) 5864285 .

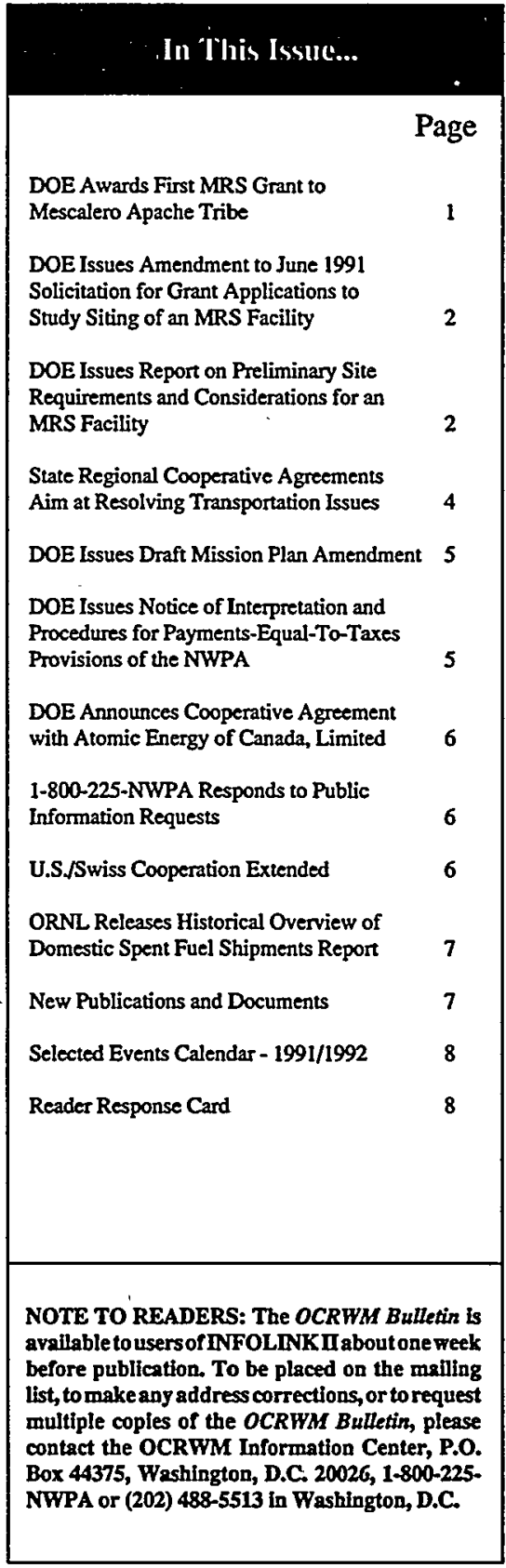

Published by the U.S. Department of Energy (DOE), Omce of Civilian Radioactive Waste Management (OCRWM)

For further information about the national program or for copies of new OCRWM publications and documents listed in the OCRWM Bulletin, contact the U.S. Department of Energy, OCRWM, Office of Extemal Relations, Education and Information Division, Mail Stop RW-5.1, 1000 Independence Avenue, S.W., Washington, D.C. 20585. (202) 586-5722 or the OCR WM Information Center.P.O. Box 44375, Washington, D.C. 20026, 1-800-225-NWPA or (202) 488-5513 in Washington, D.C. The OCRWM Information Services Directory is available to provide sources of program information. 


\section{DOE Issues Amendment To June 1991 Solicitation For Grant Applications : To Study Siting Of An MRS Facility}

The DOE is accepting applications for financial assistance from eligible States, Indian Tribes, and units of local government interested in assessing the feasibility of siting an above-ground, MRS facility for the temporary storage of commercial, spent nuclear fuel.

In response to a number of queries, DOE has issued an amendment to its June 1991 solicitation (see OCRWM Bulletin, July/ August 1991) for grant applications. The amendments clarify several points in the previous notice and broaden the scope of the study activities.

Two types of feasibility assessment grants are available. A preliminary, or Phase I, assessment grant will be for a maximum of $\$ 100,000$, and the advanced, or Phase II, grant will have no predetermined limits. Both phases of assessment grants will be awarded based upon restricted eligibility requirements as specified in the solicitation.

The activities that may be undertaken are intended to be flexible, enabling grantees to study and address specific areas in which they would like additional information, including the potential effects and benefits of hosting an MRS facility.

DOE will view an application for a grant only as an expression of interest in assessing the feasibility of possibly hosting the MRS facility. Acceptance of a grant will not be construed as a commitment on the part of the grantee or the State to host the facility, nor will it prejudice siting of the MRS either in favor of or against the grantee's jurisdiction. The deadline for applications, which will be acted upon in the order received, is December 31, 1991.

Requests for copies of the solicitation and amendment can be made in writing to the Department of Energy, Office of Placement and Administration, Attn: Ms. Kristin Wright/PR-322.2, 1000 Independence Avenue, S.W., Washington, D.C. 20585, (202) 586-4285. 艺

\section{DOE Issues Report On Preliminary Site Requirements And Considerations For An MRS Facility}

In order to provide guidance for assessing the technical suitability of potential sites for a monitored retrievable storage (MRS) facility, DOE has published a document, "Preliminary Site Requirements and Considerations for a MonitoredRetrievable Storage Facility." This document has been reviewed by the staff of the Nuclear Regulatory Commission (NRC) that will license the MRS facility.

The Secretary of Energy has.announced the availability of grants to States, Indian Tribes, and affected units of local government that want to conduct studies to assess the feasibility of hosting an MRS facility (see lead article on page 1 of this issue and OCRWMBulletin, May/June 1991). These studies will help interested States, Tribes, and affected units of local government determine whether they want to proceed to negotiations and, if so, to define the terms of the agreement they want to negotiate.

Examination of the applicable Federal statutes, regulations, executive orders, and
DOE Orders suggests that suitable sites for an MRS facility could be found throughout the contiguous United States. The preliminary site requirements are derived from Federal statutes and regulations (including Subparts E and F of 10 Code of Federal Regulations Part 27); and the preliminary site considerations identify conditions that are preferable. If a site meets the preliminary site requirements, it could then be examined in terms of the site considerations for additional favorable factors.

The preliminary site requirements and considerations are not now part of DOE's technical baseline of requirements and are not intended to cover all regulatory requirements or requirements for the license application that will be submitted to NRC. The purpose of the preliminary site requirements and considerations is to permit a reasonable determination, on the basis of available information without extensive analysis, that a site is potentially suitable for an MRS facility.
The preliminary site requirements and constraints cover the following: colocation with a geologic repository, site size, singleuse protected lands, coastal barriers, critical habitat forendangered or threatened species, and hazardous wastes. The site considerations are divided into five groups: (1). geologic and other hazards, (2) environmental factors, (3) socioeconomic factors, (4) transportation, and (5) cost and development time. A matrix showing the preliminary siting requirements and considerations together with their statutory and regulatory bases appears in Table 1 (page 3). To secure a copy of "Preliminary Site Requirements and Considerations for a Monitored Retrievable Storage Facility," please see page 7 . 


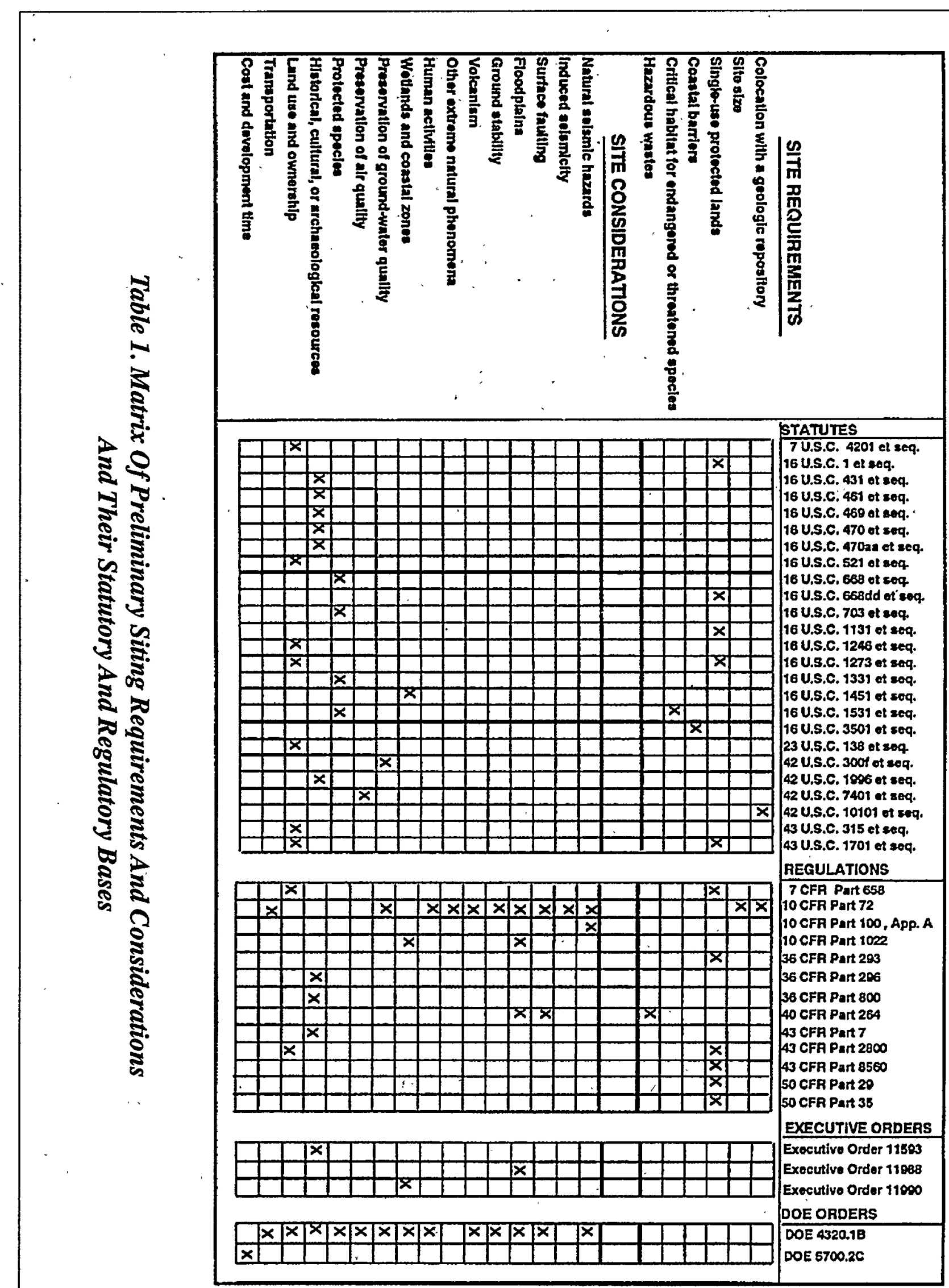




\section{State Regional Cooperative Agreements Aim At Resolving Transportation Issues}

As part of the OCRWM transportation institutional program, regional associations and State policy and agency personnel are participating in identifying and resolving key transportation issues for shipments of spent nuclear fuel and high-level waste (HLRW).

Under the OCRWM Program, cooperative efforts have been ongoing with the Western Interstate Energy Board and the Southern States Energy Board since 1984, and with the Midwestern Office of the Council of State Governments since 1989. A similar agreement with a Northeast organization of States is expected by the end of 1991. (Figure 1 shows the States in the regional groups with HLRW cooperative agreements.)

Each regional group identifies issues of interest to its participants. In the West, emergency response, routing, and rail transport have been emphasized. The Southern States have focused on emergency response, lessons learned in designating alternate highway routes, and transportation related to a monitored retrievable storage facility. The Midwest group has addressed issues such as emergency response, routing, and onsite storage of spent nuclear fuel. Each group has convened a committee of State representatives who meet to discuss the OCRWM transportation program. Committee members range from the Governor's policy staff to State agency people in charge of radiological health or emergency management in the State.

All the regional groups have developed transportation "primers" or reports thatserve as resources to describe the OCRWM program, summarize the key issues, and put the issue resolution activities in regional context for the State members. The committees define the specific issues of interest to the regions and, in conjunction with OCRWM transportation program staff, agree on the mutually-beneficial studies and reports.

Meetings are held approximately twice a year to brief the members of each regional group on the completed work and OCRWM activities, and to discuss items of importance to the States. Two specific activities have helped shape the OCRWM Transportation technical program activities. One activity has been the continued studies and discussion of emergency response planning, training, and assistance needs in relation to the OCRWM program. The other has been the recommendation to initiate a pilot inspection program to test procedures developed by the Commercial Vehicle Safety Alliance under a cooperative agreement with OCRWM. 它

\section{States Represented By Regional Groups Under Agreement With OCRWM Transportation}

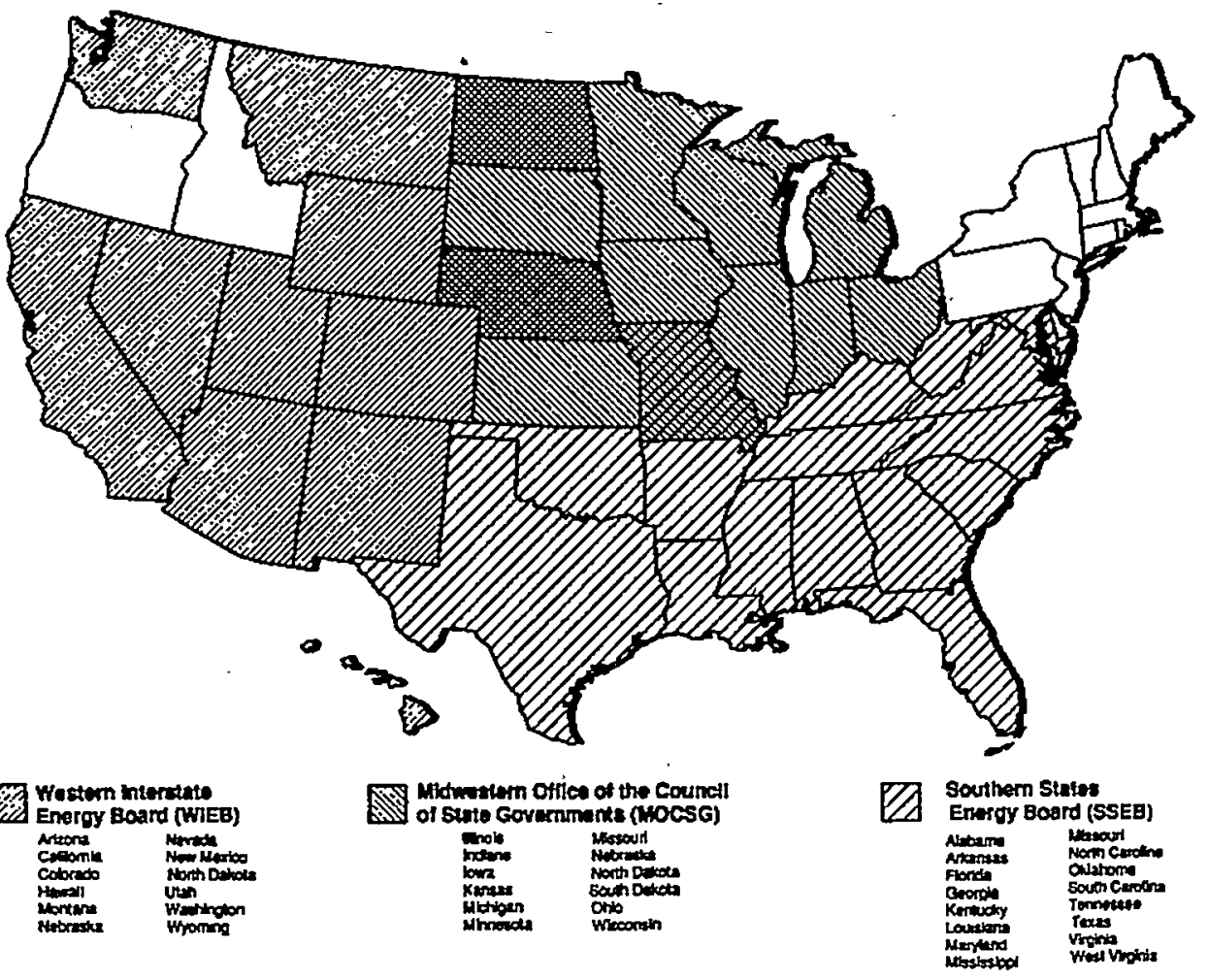




\section{DOE Issues Draft Mission Plan Amendment}

In November 1989, the Secretary of Energy issued the "Report to Congress on Reassessment of the Civilian Radioactive WasteManagementProgram." This report established an action plan that included initiatives to provide waste acceptance in 1998 at a facility formonitored retrievable storage, and waste disposal starting in 2010 in a geologic repository. This report stated that furtherdetails on the Secretary's action plan would be provided in a revised Mission Plan.

In developing the draft Mission Plan Amendment (MPA), DOE adopted an approach that is different from that used for earlier versions of the Mission Plan, and even different from what had been envisioned in November 1989. Specifically, DOE conducted a series of workshops (see OCRWM Bulletin, October/November 1990 and April 1991) with individuals from various affected governments and interested parties on the strategic principles that should guide the program over the coming years. The input of these individuals and the exchange of views at the workshops was informative, stimulating, and productive. In no small part, the shape and content of the draft MPA attest to the impact of these workshops and the contributions of the individuals who attended them.

Because of the importance of these workshops in the development of the draft MPA, a workshop was held on October 2223,1991 , in Denver, Colorado, to build on the dialogue of the previous Strategic Principles Workshops. In particular, the Denver workshop is to secure reactions to the draft MPA and to determine how well OCRWM responded to the comments and concerns expressed at the earlier workshops. This draft MPA workshop will be open to the public and will follow the same ground rules that encouraged diverse parties to express their views freely as in the past.

The draft Mission Plan Amendment is being made available for comment by Federal agencies, States, Indian Tribes, and units of local government; the utilities; the National Association of Regulatory Utility Commissioners; other interested parties; and the public. Written comments on the draftMission Plan Amendment should be submitted by November 8,1991 , after which the formal comment period will be closed. Comments should be addressed to:

Thomas H. Isaacs, Director, Office of Strategic Planning and International Programs, Office of Civilian Radioactive Waste Management, U.S. Department of Energy, RW-4, 1000 Independence Avenue, S.W., Washington, D.C. 20585.

Additional copies of the draft MPA can be obtained by calling (202) 586-5722. Afterall comments on the document have been considered, appropriate revisions will be made to the draft Mission Plan Amendment, and it will be submitted to Congress.

\section{DOE Issues Notice Of Interpretation And Procedures For Payments-Equal-To-Taxes 'Provisions Of The Nuclear Waste Policy Act Of 1982}

The Nuclear Waste Policy Act of 1982 (NWPA), as amended, provides thatDOE will make payments-equal-to-taxes (PETT) to eligible States, affected units of government, and affected Indian Tribes for activities related 'to siting, development, and operation of a repository for the permanent disposal of spentnuclear fuel and high-level radioactive waste, and any monitored retrievable storage (MRS) facility.

The scope of the Notice, issued by DOE on August 27, 1991, is limited to site characterization activities related to the repository or MRS facility. Development and operational phases of the repository and MRS facility will be addressed at a later date. The jurisdictions involved are eligible for payments equivalent to the amount they would receive if authorized to tax the Federal site characterization activities at such site.

The Notice incorporates DOE's response to public comments received on a Proposed Notice issued on March 7, 1990. Based on comments received, and after further consideration, DOE has revised its proposed interpretation and procedures by (1) modifying the proposed geographical basis for determining which site characterization activities are eligible for inclusion in PETT calculations, and (2) giving eligible jurisdictions the opportunity to provide to DOEestimates of PETT, including the basis for such calculations. Because PETT payments are not tax payments but payments made by DOE pursuant to statute, DOE has the responsibility to determine the amount of PETT based on the information provided by the eligible jurisdictions, as well as applicable DOE accounting directives and standards. DOE will document its analysis of this information and calculation of the PETT.

DOE recognizes that a potential exists for differences between the PETT estimates developed by eligible jurisdictions and the amount calculated by the Department. Therefore, DOE has provided for an appeal process through its Office of Hearings and Appeals (OHA) for those jurisdictions having disputes with the DepartmentregardingPETT. While OHA would issue the final determination of DOE on PETT disputes, it is subject to review in the Federal courts. 


\section{DOE Announces Cooperative Agreement With Atomic Energy Of Canada, Limited}

On October 1, 1991, DOE announced that OCRWM has concluded an agreement with Atomic Energy of Canada, Limited (AECL) to cooperate on conducting technical activities for the disposal of spent nuclear fuel and high-level waste. By cooperating with Canada on technical issues related to nuclear waste management, this international project supports President - Bush's National Energy Strategy and will be instrumental in developing technologies to be used in support of the Yucca Mountain Site Characterization Project.

The new project agreement will involve cooperative experimental and analytical activities associated with geoscientific and engineering aspects of a mined geologic repository for high-level nuclear waste. The project agreement will develop new data and improve technologies in a cost-effective fashion, allow for further experience for U.S. personnel, and gain access to additional generic information and exclusive research facilities.
AECL operates unique surface and subsurface facilities not readily available in the United States. Scientists and engineers who support AECL research in Manitoba and the Yucca Mountain Site Characterization Project Office in Nevada will cooperate in performing the technical work.

This agreement is linked to a Master Agreement DOE and AECL signed in 1982 and extended in 1987 establishing general provisions for cooperation on topics associated with the managment of radioactive waste. The United States will benefit from the new agreement by assuring that the appropriate technology, procedures, and instrumentation are available when required during U.S. site characterization activities.

负

\section{1-800-225-NWPA Responds To Public Information Requests}

The OCRWM Information Center has received and responded to numerous telephone inquiries and requests to its new toll-free number, 1-800-225-NWPA, since the startup of the 800 number information system on September 16, 1991. This system provides a convenient, centralized mechanism forall interested parties to obtain timely information about the Nation's highlevel radioactive waste management program. In the past two weeks, 800 number calls have been received from practically every region of the United States, reflecting the interests of educators, students, libraries, federal and State officials, electric utilities, and other members of the public.
Should you have a question about the program or wish to request information or publications, the 800 number system can be accessed by dialing 1-800-225-NWPA (6972), except in Washington, D.C., where callers may dial 488-5513. The OCRWM Information Center's hours are Monday through Friday, 9:00 a.m. to 7 p.m. Eastern Standard Time. Written inquiries and comments are welcomed and may be directed to the OCRWM Information Center, P.O. Box 44375, Washington, D.C. 20026.<smiles>[Y17][3H]</smiles>

\section{U.S./Swiss Cooperation Extended}

On September 23, 1991, DOE and Switzerland's National Cooperative for the Disposal of Radioactive Waste (NAGRA) signed an agreement to extend their umbrella agreement and to establish a new project. The extended umbrella agreement will continue through September 1996 and focuses on exchange of personnel and technical information. NAGRA operates unique facilities not available in the United States, giving DOE the opportunity to test critical instrumentation, computer models, and field methods.

The project agreement deals with the geological, geophysical, geochemical, hydrological, and structural effects from a mined geologic radioactive waste repository. The new project agreement will be very important to U.S. efforts at the Yucca Mountain Project Site, as it will stress the effects of the flow of ground water and radionuclide transport on a repository in a fractured rock formation. The technical publications and data produced from previous agreements are presently being used in U.S. research activities.

$$
\text { 约 }
$$

\section{Continued from page 5}

Copies of the Notice and documents referred to in the Notice are available for public review at DOE Headquarters reading room, 1000 Independence Avenue S.W., Room 1E-190, Washington, D.C. 20585, (202) 586-6020; Nevada Operations Office reading room, 2753S. Highland, Las Vegas, NV 89109, (702) 295-1274; and the Richland Operations Office reading room, 825 Jadwin, Richland, WA 99352, (509) 376-8583. For further information, contact Allen Benson, Office of External Relations, Office of Civilian Radioactive Waste Management, U.S. Department of Energy, RW-5, 1000 Independence Avenue, S.W., Washington, D.C. 20585, (202) 586-2289. 


\section{ORNL Releases Historical Overview Of Domestic Spent Fuel Shipments Report}

The Oak Ridge National Laboratory (ORNL) recently finished compiling data for OCRWM that comprises an historic overview of commercial and research reactor spent fuel shipments made in the United States between 1964-1989. Data collected during the 25-year period include the sources of commercial and research reactor spent fuel shipped, the types of shipping casks used, the number of fuel assemblies shipped, and the number of shipments made: This report, Historical Overview of Domestic Spent Fuel Shipments - An Update (ORNL/Sub/88997962/1), is intended for planning purposes to support program decisions of OCRWM and to inform the interested public and representatives from Federal, State, and local governments; Indian Tribes; and the transportation community.

Analysis of the commercial spent fuel data produced a number of observations. During the period of 1964-1989, approximately 2600 commercial shipments were made, totalling about 1900 metric tons of spent fuel (MTU) shipped. Ninety-one percent of the shipments, which represented only 52 percent of the spent fuel by weight, was carried by truck.

Although the greatest number of fuel assemblies was moved in 1986 , the greatest number of shipments was made in 1974. Due to the greater capacity of the rail casks used in later campaigns as compared with truck casks that were used mostly in the earlier campaigns, the number of cask shipments decreased from 224 in 1974 to 144 in 1986.

The amount of spent fuel shipped reflects 4 periods of major activity: (1) the mid 1960's, (2) the early 1970's, (3) the mid 1970's, and (4) the mid to late 1980's. These periods correspond with the startup of the Nuclear Fuel Services West Valley plant (NFSWest Valley) in New York (1964-1966), additional shipments for commercial reprocessing at NFS-West Valley (19711974), storage at GE-Morris in Illinois (mid 1970 's), and the decommissioning of NFSWest Valley (1984-1986), and GE-Morris contract shipments (1984-1989), respectively. spent fuel for reprocessing until 1976, when reprocessing was discontinued. Decommissioning of the plant meant that all of the commercially owned, spent fuel onsite had to be shipped back to the utilities' own storage pools. A small amount of spent fuel remains in storage at the West Valley facility. Shipment of this spent fuel to a DOE facility is pending. GE-Morris never operated as a reprocessing plant, even though it was designed for reprocessing and did accept spent fuel from 1972-1989.

Three motor carriers participated in the majority of shipping campaigns involving truckshipments: Tri-State Motor Transport, Home Transport, and McGil Specialized Carriers. Spent-fuel shipments have been historically dominated by a few carriers. These carriers have chosen to provide the driver training, specialized equipment, and communications operation needed to support shipments of spent fuel.

Shipments made from reactors used for research and test purposes (reactors from universities and DOE reactors) during the period 1983-1989 were all made by truck with 236 shipments and 20.2933 MTU being transported. The largest number of research reactor fuel shipments took place in 1986 with the largest campaigns occurring between Brookhaven National Laboratory in Brookhaven, New York, to the Idaho Chemical Processing Plant(ICPP) in Idaho, the Oak Ridge National Laboratory High Flux Isotope Reactor (HFIR) in Tennessee, and the Rockwell International Reactor in California to the Receiving Basin for Offsite Fuels (RBOF) at Savannah River in South Carolina.

This report is available to DOE and DOE contractors from the Office of Scientific and Technical Information, P.O. Box 62, Oak Ridge, Tennessee 37831. Copies are available to the public from the National Technical Information Service, U.S. Department of Commerce, 5285 PortRoyal Road, Springfield, Virginia 22161.
NFS-West Valley received shipments of

\section{New Publications And Documents}

Draft Mission Plan Amendment, DOE/ RW-0316P, September 1991.

The DraftMission Plan Amendmentreports plans for the Civilian Radioactive Waste Management that include initiatives to provide waste acceptance in 1998 at an MRS facility and waste disposal starting in 2010 in a geologic repository.

Preliminary Site Requirements and Considerations for a Monitored Retrievable Storage Facility, DOE/RW0315P, August 1991.

This report presents preliminary requirements and considerations for siting a monitored retrievable storage (MRS) facility. Its purpose is to provide guidance for assessing the technical suitability of potential sites for the facility.

NOTE: To order copies of new OCRWM publications and documents listed in the OCRWM Bulletin, contact the OCRWM Information Center, P.O. Box 44375, Washington, D.C. 20026, 1-800-225NWPA or (202) 488-5513 in Washington, D.C. 绝 


\section{Selected Events Calendar - 1991}

November 6-7

November 12-13

November 19

November 20

December 1-6

December 5-7

January $15-17$
Secretary of Energy Advisory Board, Task Force on Civilian Radioactive Waste Management Meeting, Thomas and Mack Center, University of Nevada-Las Vegas, Las Vegas, NV. Contact Dan Metlay (202) 586-7092.

Nuclear Waste Technical Review Board, Panel on Structural Geology and Geoengineering, Meeting on Technology of Backfill, Sealing, and Openings; Exploratory Studies Facility Design Review. Seattle, WA, Wyndham Garden Hotel. Contact Paula Alford (703) 235-4473.

DOE/Nuclear Regulatory Commission Meeting on Regulatory Strategy, location to be determined in Washington, D.C. area. Contact Linda Desell (202) 586-1462.

DOE/Nuclear Regulatory Commission Interactions Meeting, location to be determined in Washington, D.C. area. Contact Linda Desell (202) 586-1462.

National Congress of American Indians 48th Annual Convention, San Francisco, CA. Contact Carol Gipp (202) 546-9404.

National Science Teachers Association Meeting, Reno, NV. Contact Ellie Snyder (202) 328-5800, ext. 44.

\section{2}

Nuclear Waste Technical Review Board, Full Board Meeting, location to be determined in Washington, D.C. Contact Paula Alford (703) 235-4473.

Institute of Nuclear Materials Management, Ninth Spent Fuel Seminar, Loew's L'Enfant Plaza, Washington, D.C. Contact Barbara Scott (708) 480-9080.

\section{Reader Response Card}

A reader response page is enclosed with every OCRWM Bulletin. The purpose of this page is to encourage communication between the readers of the Bulletin and OCRWM.

Your views, comments, and suggestions are appreciated so that we can make the OCRWM Bulletin as useful and responsive to our readers as possible.

Comments:

Name:

Address:

Affiliation:

Please detach this page and mail to: Mr.Jerome Saltzman, Director • Office of External Relations $\bullet$ Office of Civilian Radioactive Waste Management U.S. Department of Energy • Mail Stop RWW 5.1 • 1000 Independence Avenue, SW •Washington, DC 20585 


\section{OCRWM Bulletin}

United States Department Of Energy • Office Of Civilian

Radioactive Waste Management

Washington, DC 20585

November/December 1991

\section{DOE Awards Second MRS Grant To Grant County, North Dakota}

On November 25, 1991, DOE awarded a grant to Grant County, North Dakota, to study the feasibility of siting an aboveground, monitored retrievable storage (MRS) facility for the temporary storage of commercial spent nuclear fuel.

The grant, awarded for nearly $\$ 100,000$, will be used by Grant County to gain an understanding of the Nation's nuclear waste managementsystem, including the MRS facility component, and to determine whether it has an interest in pursuing further feasibility studies. This is the second grant awarded for a feasibility study. The Mescalero Apache Tribe of New Mexico was awarded a grant for the amount of $\$ 100,000$ on October 17,1991 (see OCRWMBulletin, September/October 1991).
The MRS facility will be an above-ground storage facility using proven technology to the maximum extent practicable. The facility will receive, temporarily store, and stage spent nuclear fuel for shipment to a permanent geologic repository for ultimate disposal. The MRS facility will be subject to licensing by the Nuclear Regülatory Commission and to applicable federal and State environmental, safety, and health regulations.

Grant applications for feasibility studies are currently being accepted. Requests for copies of the solicitation can be made in writing to the Department of Energy, Office of Placementand Administration, Attn: Mr. Nick Graham/PR-322.1, 1000 Independence Avenue, SW, Washington, D.C. 20585, (202) 586-9634.

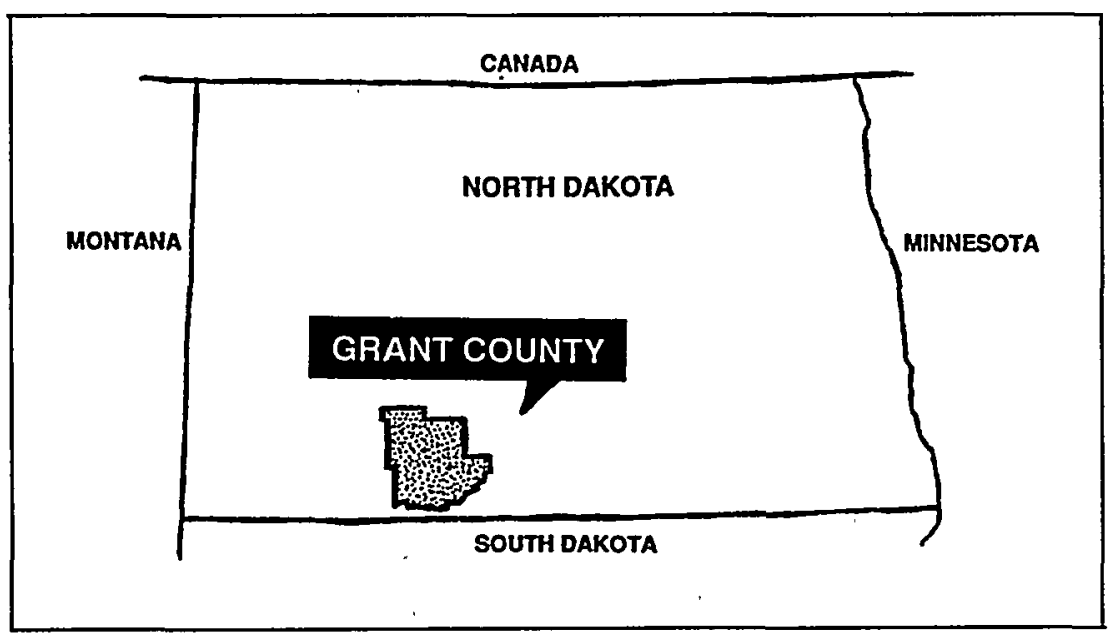

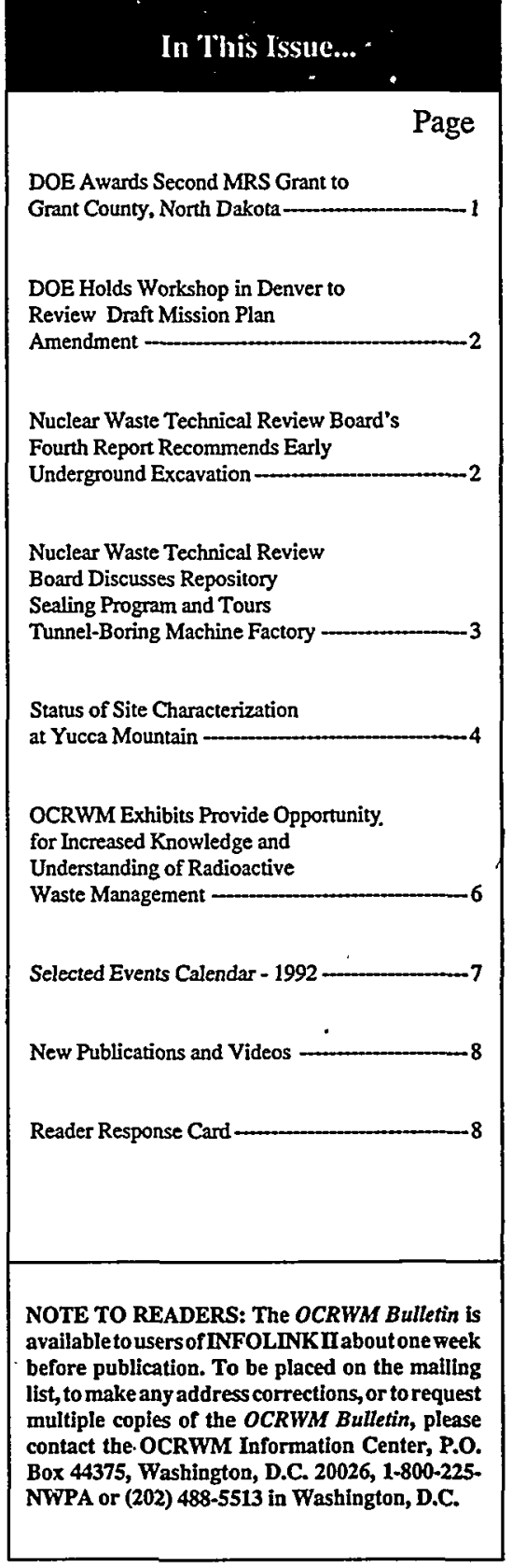

Published by the U.S. Department of Energy (DOE), Office of Civilian Radioactive Waste Management (OCRWM)

For further information about the national program or for copies of new OCRWM publications and documents listed in the OCRWM Bulletin, contact the U.S. Department of Energy, OCRWM, Office of Extemal Relations, Education and Information Division, Mail Stop RW-5.1, 1000 Independence Avenue, S.W., Washington, D.C. 20585, (202) 586-5722 or the OCRWM Information Center, P.O. Box 44375, Washington, D.C. 20026, 1-800-255-NWPA or (202) 488-5513 in Washington, D.C. The OCRWM Information Services Directory is available to provide sources of program information. 


\section{DOE Holds Workshop In Denver To Review Draft Mission Plan Amendment}

On October 22-23, 1991, OCRWM held a workshop in Denver, Colorado, to review the draft Mission Plan Amendment (MPA). Twenty-four individuals from the State of Nevada; local govemments in Nevada and California; the utilities; scientific, public interest, and other groups; and other Federal agencies participated in the workshop.

The final MPA is intended to be the waste management program's guideline and will report on how OCRWM intends to achieve its mission to manage and dispose of the Nation's spent nuclear fuel and high-level waste in a manner that protects the health and safety of the public and of workers and the quality of the environment. OCRWM issued the draft MPA on September 16, 1991, for a 60-day public comment period.

The primary objective of the draft MPA workshop was to enable affected governments and interested parties to discuss and respond to the draft MPA. The workshop was planned as a follow-up to the three previous Strategic Principles Workshops heldearlierin the year to develop management, technical, and institutional principles needed to guide the program (see OCRWM Bulletin, April 1991).

The draft MPA workshop's participants examined how well OCRWM had integrated the strategic principles into the draft MPA and submitted comments on its substantive content. Although the draftMPA did receive criticism and suggestions for improvements, the participants complimented OCRWM for presenting a well-written, organized document and expressed appreciation for the opportunity to participate in the workshop.

In addition, OCRWM presented plans at the workshop for a "Director's Forum" to provide ongoing participation by affected governments, interested parties, and the public. While the concept of a Director's Forum as presented was not fully developed, participants at the workshop responded positively to continuing this kind of interchange. The Forum will meet on an asneeded basis to provide input to significant upcoming program decisions and to evaluate OCRWM's efforts to strengthen public trust and confidence. The initial Forum meeting will be held in the spring of 1992 .

The public comment period for the MPA ended on November 8, 1991. OCRWM plans to incorporate appropriate comments into the revised document, prepare a comment response document, and issue the final MPA in April 1992. 录

\section{Nuclear Waste Technical Review Board's Fourth Report Recommends Early Underground Excavation}

On December 10, 1991, the Nuclear Waste Technical Review Board (the Board) submitted its Fourth, Report to the U.S. Congress and the Secretary of Energy. This report, which represents the Board's most recent scientific and technical review of DOE's civilian radioactive waste disposal program, expresses its concern that DOE's postponement of underground excavation due to funding restrictions will delay the exploration of key geologic features necessary for the early assessment of site suitability. Further, the Board is concerned about the potential effects that postponing underground excavation and evaluation could have on achieving the major milestones of the repository development program, especially meeting key program target dates, assuming that the site is found to be suitable.

The report recommends that DOE revise its program to include earlier underground excavation. The Board feels that early underground access to examine and evaluate key geologic features is critical to determining site suitability, and it believes that these activities should be made an early goal regardless of DOE budgetary constraints.

The Board also recommends that, in light of recent budgetary constraints, DOE should consider developing contingency plans for fiscal year 1993 and beyond. This will enable DOE to proceed with the program even during times of budgetary uncertainty. Such plans would ensure that underground exploration would be given high priority, allowing DOE to progress toward the major milestones of the program in a timely and efficient manner.

Further Board recommendations include:

\section{Structurál Geology and Geoengineering}

- Smaller tunnels. (16- to 20-foot diameters) be considered for the ramps and exploratory tunnels, offering benefits such as reduced excavation volumes, lower ventilation requirements, and smaller surface facilities. Also, smaller, less expensive tunnel-boring machines could be used.

Continued on page 3 


\section{Continued from page 2}

- Using a structured probabilistic approach that can provide useful estimates of volcanic hazard at Yucca Mountain and help discriminate between those differences in input assumptions that have a significant impact on volcanic hazard and those that do not.

- Place an added emphasis on the evaluation of volcanic vulnerabilities and consequences.

\section{Hydrology and Geochemistry}

- Carry out sensitivity studies to determine the effect of limitations in instrument accuracy on estimates of water flux and performance in the unsaturated zone. The results of these studies should be used to refine testing strategies, determine the need for new instrumentation, and provide a realistic estimate of DOE's ability to adequately characterize the unsaturated zone.

\section{Engineered Barrier System (EBS)}

- Studies of the potential contribution of engineered barriers, such as multipurpose canisters, should not be deferred.

- The Department should consider organizing a follow-up meeting of EBS workshop experts plus other selected participants in early 1992 to review and consolidate the recommendations and comments aboutEBS concepts gatheredatDOE's June 1991 workshop.

\section{Environment and Public Health}

- DOE should seek clarification from the Nuclear Regulatory Commisșion (NRC) of the procedures by which alternative levels of subsystem performance could be authorized.

\section{Risk and Performance Analysis}

- The Department should refine its methods for assessing expert judgment, and DOE and NRC should attain agreement on the potential use of experts prior to beginning the licensing process. A workshop should be held in 1992 to examine the use of expert judgment in 'DOE's current performance assessment and in the performance assessment exercises carried out by other organizations such as NRC, the Electric Power Research Institute; and Golder Associates, an to propose improvements.

The Board's Fourth Report to the U.S. Congress and the Secretary of Energy is available for $\$ 5.50$ from the Superintendent of Documents, U.S. Government Printing Office, Mail Stop: SSOP, Washington,D.C. 20402-9328.

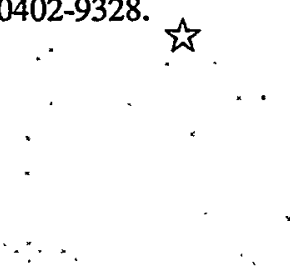

\section{Nuclear Waste Technical Review Board Discusses Repository Sealing Program And Tours Tunnel-Boring Machine Factory}

As part of its congressional mandate to independently review DOE's Civilian Radioactive Waste Management Program, the Nuclear Waste Technical Review Board's Panel on Structural Geology \& Geoengineering met with DOE representatives and its contractors on November 12 and 13, 1991, in Seattle, Washington. During the two-day meeting, panel members reviewed DOE's plans for sealing and backfilling repository boreholes, shafts, tunnels, and underground openings. In addition, panel members toured The Robbins Company, the world's largest manufacturer of tunnel-boring machines.

On the first day, panel members were briefed on the status of the proposed repository sealing program. Presentations focused on the program's history, regulatory requirements, design philosophy, sealing concepts, and the rationale for these concepts. Following discussions concentrated on the technical requirements of sealing and the development of a numerical model of the permeability of the zone surrounding the openings of the proposed repository. The model's purpose is to demonstrate sealing performance in response to potential water flow into the repository, and potential gaseous flow out of the repository or around sealed and backfilled boreholes, shafts, tunnels, and underground openings.

On the second day, following discussions on the materials selection process, seal degradation, and proposed field test efforts, panel members were given a half-day tour of The Robbins Company.

Transcripts of the meeting are available on a library-loan basis from Victoria Reich, librarian, U.S. Nuclear Waste Technical Review Board, 1100 Wilson Boulevard, Suite 910, Arlington, VA 22209. 次 


\section{Status Of Site Characterization At Yucca Mountain}

\section{Surface-Based Testing}

The site characterization program recognizes the importance of making an early evaluation of site suitability at the candidate site for the Nation's first geologic repository for spent nuclear fuel and high-level waste at Yucca Mountain, Nevada. For this reason, and after an initial evaluation of priorities for surface-based and in-situ testing, it has been determined that an early emphasis of investigation at the candidate site will be on

- determining the potential for gaseous releases over the long term, and

- resolving the geologic complexity of the site as related to radionuclide migration by ground-water transport.

To pursue these areas of emphasis through surface-based testing as soon as possible, 12 neutron boreholes, onsite dry drilling, and coring of deep boreholes into the unsaturated zone will begin early in 1992 .

Characterization of rocks and ground water in the unsaturated zone at Yucca Mountain presents considerable challenges. Contamination by drilling fluids of the rocks surrounding the borehole and of samples removed from the borehole must be avoided or minimized. Testing and sampling must be conducted under conditions as close as possible to the original conditions of the rock. To achieve these goals, OCRWM plans to use dry drilling and coring for many boreholes at Yucca Mountain rather than standard drilling techniques that use drilling fluids.

Prototype drilling activities in Utah and Arizona have been conducted (see OCRWM Bulletin, June 1990 and July/August 1991). Results of these activities led to improvements in the design of the LM-300, a larger drilling rig that will be used at Yucca Mountain for drilling deep boreholes. The LM-300 has completed acceptance testing and has been brought to Yucca Mountain to begin site characterization drilling in early 1992. The prototype operations also provided an opportunity for the Sample Management Facility to refine procedures for handling drilling samples.

In addition to the planned drilling, trenching will be undertaken for detailed studies of faults, the characteristics of soils and rocks, and evidence of past climates (see OCRWM Bulletin, July/August 1991). In the area of Yucca Mountain, OCRWM has excavated about 40 trenches and plans to excavate approximately 25 new trenches, the first of which was completed in July 1991 (see photo on page 5). This activity will continue throughtout 1992. Most of these trenching activities are undertaken to determine the timing of the faulting and the amount of fault displacement, and to look for any evidence of recurrent displacement. The study of surface characteristics, investigation of past climates, and volcanic issues will also require new trenches, possibly as many as 40 , but these will be shorter and shallower than those trenches excavated for fault studies. These trench locations will be selected from aerial photographs and field reconnaissance.

Ongoing monitoring activities are continuing, including the monitoring of meteorological conditions, streamflow, seismicity, and ground-water levels.

\section{Exploratory Studies Facility}

In addition to the surface-based testing program, OCRWM plans to construct an exploratory studies facility (ESF) at Yucca Mountain to provide access to the potential host rock for a repository and to evaluate the geologic, hydrologic, geochemical, geomechanical, and thermal conditions in the potential host rock and the surrounding units. Original plans for the ESF were reviewed by the Nuclear Regulatory Commission and the Nuclear Waste Technical Review Board, and their recommendations led to a major review known as the ESF Alternatives Study.

The ESF Alternatives Study was a comprehensive, formal evaluation of configuration and construction alternatives for the ESF that also considered preferred options for interface of the ESF and the repository design. The results of the study indicate that an ESF providing access to both the candidate repository horizon and the underlying Calico Hills unit through mechanically excavated ramps could provide advantages over the original configuration of the ESF that called for two vertical shafts. The ESF will include an underground test facility and horizontal drifts to characterize major geologic features.

The most favorable aspects of the alternatives considered were combined into a revised design concept that has provided the basis for the revised ESF Title I Design Summary Report. This report was completed in September 1991 and accepted by OCRWM Director, Dr. John W. Bartlett. Approval to proceed with limited ESF Title II design has been granted by the Undersecretary of Energy who is responsible for overseeing major program acquisitions for the program.

th 


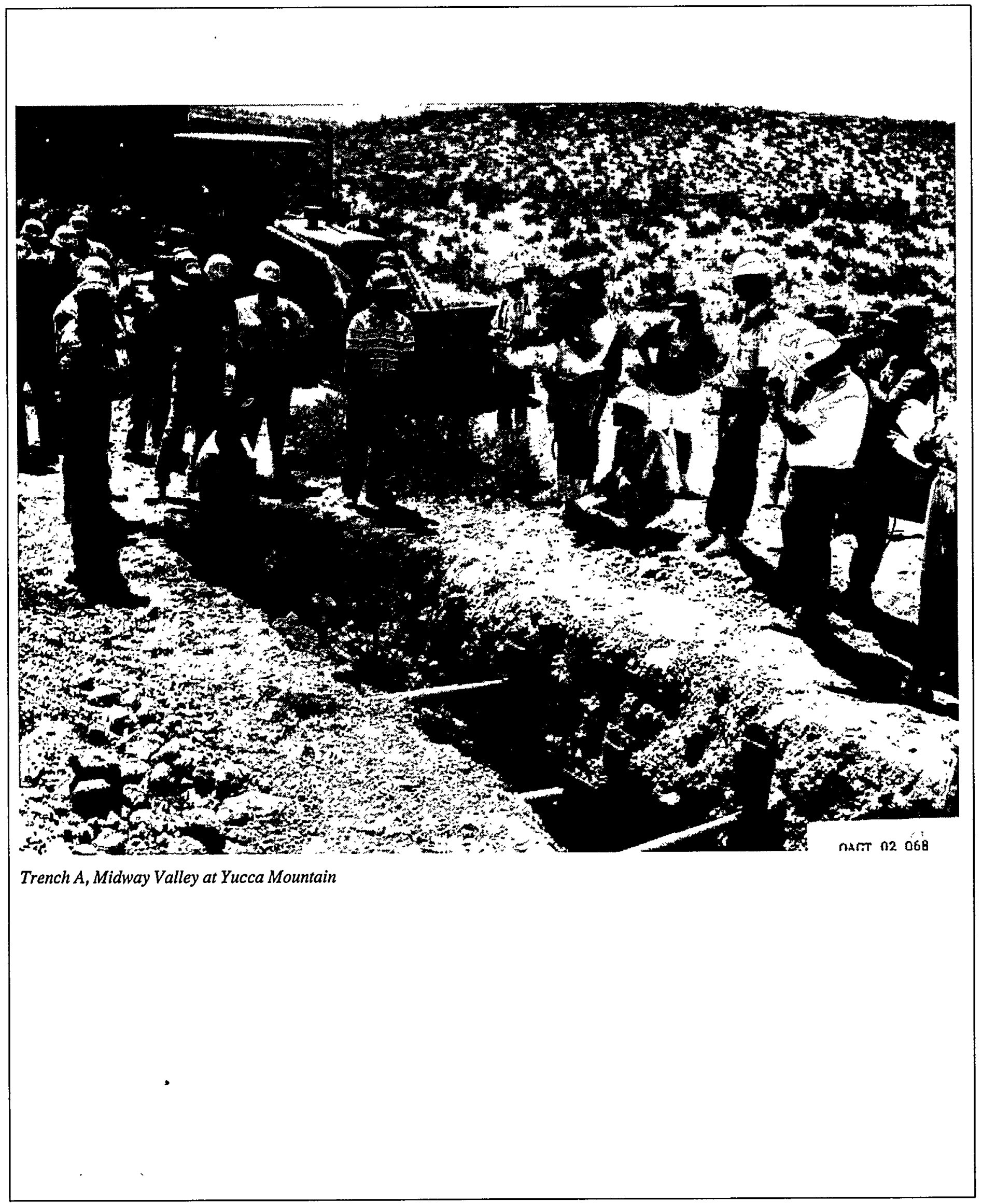




\section{OCRWM Exhibits Provide Opportunity For Increased Knowledge And Understanding Of Radioactive Waste Management}

Science education has long been a critical element in DOE's Civilian Radioactive Waste Management Program. To that end, OCRWM has developed educational programs aimed at improving the science literacy of students from kindergarten through college and post-graduate levels, enhancing teacher skills, encouraging careers in science and engineering, and developing a keener awareness of science issues among the general public. Among these varied educational activities, OCRWM's Education and Information Division, Office of External Relations, has developed specialized travelling exhibits for presentation at technical and non-technical meetings and at national and regional teacher/educator conferences to provide an overview of the integrated waste management system.

The OCRWM exhibits, entitled "Managing the Nation's Nuclear Waste," consist of both full-size and tabletop displays. The full-size exhibit (see photo) has two video

Continuted on page 7

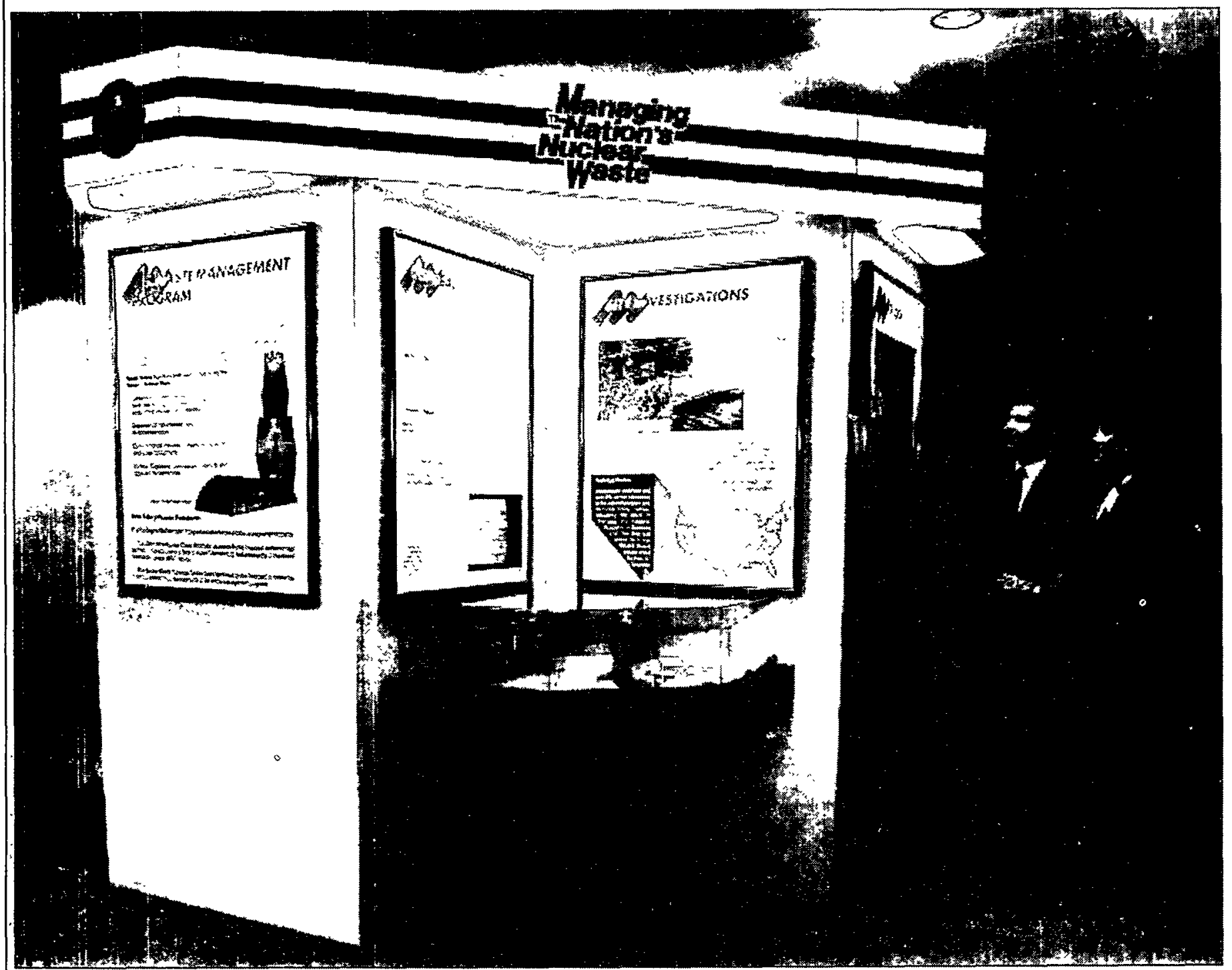

OCRWM Full-Size Exhibit 


\section{Continuted from page 6}

monitors, offers numerous free publications, and describes the U.S. Waste Management Program, types of nuclear waste, site investigations, disposal, storage technology, and transportation. The tabletop exhibit is a five-panel display that also describes the program and offers free publications.

The 1992 schedule for showings of the OCRWM exhibits consists of 41 showings in 26 states - exposing the exhibits to a potential audience of 183,800 . This represents an effort to maintain relationships established in previous years while reaching 52,000 attendees through nine new shows. An emphasis has been made to reach educators, who make up 52 percent of the year's total attendees. The second largest audience, at 19 percent, is the general public, representing 34,800 attendees.
Because the transportation of spent nuclear fuel and high-level waste will receive significant public attention in the future, specialized exhibits and other outreach activities have been developed to enhance the public's perception and understanding of transportation safety and risk. The new transportation exhibit is now available and will be helpful in providing updated information to the public on OCRWM's transportation program. The modular traveling exhibit provides models of the new rail and truck cask initiatives as well as photographs and graphics of transportation activities and developments specific to the Civilian Radioactive Waste Management Program.

The new OCRWM transportation exhibit will be shown at various educational symposia; State, Tribal, and local conferences and meetings; and conventions for professional and technical organizations.

To schedule the "Managing The Nation's Nuclear Waste" exhibit, or to obtain more information on its availability, please contact: Christina Maher, OCRWM Information Center, P.O. Box 44375, Washington, D.C. 20026, 1-800-225NWPA. Scheduling information regarding the OCRWM transportation exhibit may be obtained by contacting: Susan Smith, Office of Storage and Transportation, Office of Civilian Radioactive Waste Management, U.S. Department of Energy, RW-431, 1000 Independence Avenue, S.W., Washington, D.C. 20585, (202) 586-5616. 放

\section{Selected Events Calendar - 1992}

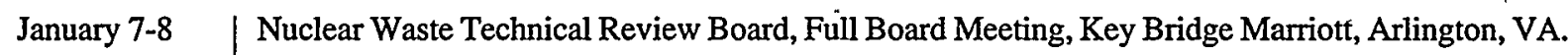
Contact Paula Alford (703) 235-4473.

January $10 \quad$ House Interior and Insular Affairs, Subcommittee on Energy and the Environment (Chairman Kostmayer), Field Hearing on Yucca Mountain permitting provisions in the National Energy Strategy Act, H.R. 1301, University of Nevada - Las Vegas, Las Vegas, Nevada. Contact Subcommittee staff at (202) 226-4085.

January 15-17 Institute of Nuclear Materials Management, Ninth Spent Fuel Seminar, Loew's L'Enfant Plaza, Washington, D.C. Contact Barbara Scott (708) 480-9573.

January 22-23 Nuclear Waste Technical Review Board, Panel on Structural Geology and Geoengineering, Meeting (topic: seismic vulnerabilities), Hyatt Regency, Irvine, CA. Contact Paula Alford (703) 235-4473.

February 10-11 Nuclear Waste Technical Review Board, Panel on Engineered Barrier System Management, Meeting (topic: overview of defense high-level waste management activities), location to be determined in Augusta, GA. Contact Paula Alford (703) 235-4473. 


\section{New Publications And Videos}

\section{NEW PUBLICATIONS:}

Spent Fuel Storage at the Monitored Retrievable Storage Facility, DOE/RW0324P, December 1991.

This fact sheet provides basic information about Monitored Retrievable Storage (MRS) through text and illustration. It describes several possible design concepts for an MRS facility and presents the differences between them by examining the various technologies being considered, including concrete and metal containers, transportable storage containers, concrete modules, and modular vaults.

\section{NEW VIDEOS:}

Monitored Retrievable Storage, 8 minutes, 15 seconds.

A description of a Monitored Retrievable Storage facility, how it might look and operate, andits role in the wastemanagement system.

k:

World Wide Waste Management, 20 minutes.

A look at what other countries are doing in the area of nuclear waste management. This provides a good description of the international consensus for deep geologic disposal and each country's plan to proceed with this issue.

NOTE: To order copies of new OCRWM publications and videos listed in the OCRWM Bulletin, contact the OCRWM Information Center, P.O. Box 44375, Washington, D.C. 20026, 1-800-225NWPA or (202) $488-5513$ in Washington, D.C. 承

\section{Reader Response Card}

A reader response page is enclosed with every OCRWM Bulletin. The purpose of this page is to encourage communication between the readers of the Bulletin and OCRWM.

Your views, comments, and suggestions are appreciated so that we can make the OCRWM Bulletin as useful and responsive to our readers as possible.

Comments:

Name:

Address:

Affiliation:

Please detach this page and mail to: Mr. Jerome Saltzman, Director - Office of External Relations $\bullet$ Office of Civilian Radioactive Waste Management U.S. Department of Energy • Mail Stop RW $5.1 \cdot 1000$ Independence Avenue, SW • Washington, DC 20585 


\section{United States Department of Energy Office of Civilian Radioactive Waste Management Washington, DC 20585 \\ 1991 Index}

\section{Bulletin}

Advisory Committee on Nuclear Waste, 10

Affected units of local government extension of affected county status, 39

American Indian Tribes hosting of nuclear waste facilities, 2 Mescalero Apache Tribe, 63, 71 MRS feasibility grant awarded, 63 National Congress of American Indians, 16 and participation in environmental studies, 3 and potential negotiated MRS site, 41 public participation, 6 Shoshone-Bannock Indian Tribes, 6 training of public safety officials, 37

Atomic Energy of Canada, Limited (AECL), 68

Babcock \& Wilcox, 31

Brookhaven National Laboratory, 69

Clark County, Nevada, 6, 37

Code of Federal Regulations

Subparts 3 and F of 10 CFR 29, 64, figure 65

Commercial Vehicle Safety Alliance (CVSA), $6,49,66$, figure 60 pilot study milestones for inspection procedures, 60

\section{Conference of Radiation Control Program \\ Directors and drafting of radiological inspection procedures, 59}

\section{Conferences}

Second International High-Level Radioactive

Waste Management Conference, 14 , program 15
Cooperative agreements and vehicle inspection procedures, 59

Costs (see Funding)

\section{Counties}

Clark County, Nevada, 6, 37

Esmeralda County, Nevada, 28, 39

Grant County, North Dakota, 71

Inyo County, California, 28

Lander County, Nevada, 39

Lincoln County, Nevada, 37

Mineral County, Nevada, 39

Nye County, Nevada, 37, 39

White Pine County, Nevada, 39

Duke Engineering, 31

\section{E.R. Johnson Associates, 31}

Engineered Barrier System (EBS), 16, 73

Environment

Environmental Program Overview, 13

Environmental Protection Implementation Plan (EPIP), 13

priority during field activities, 29

program, 13

refusal to grant environmental permits, 13

studies of

coordination and integration, 3

desert tortoise, 5

and Yucca Mountain Project, 13

Environmental Protection Agency (EPA), 2 and endorsement of Section 511 amendment, $40-41$

Esmeralda County, Nevada, 28, 39

Eureka County, California, 39

The cited reference numbers represent the page numbers of a compilation of 1991 OCRWM Bulletins. This pagination can be found at the bottom of each page and supplements each issue's notation. 91:79 
Exploratory Shaft Facility, 5

exploratory shaft pending resolution of suit by

State of Nevada, 13

review of quality assurance program, 13

\section{Exploratory Studies Facility, 74}

Federal Emergency Management Agency (FEMA), 6

Fluor Daniel, 31

Funding

amendment to financial assistance funding, 64 benefits agreements with host States and communities, 31

budget request (FY 1992), 9-10, table 9 ,

figure 10

cost containment, 29

costs

of delay in repository operations, 14

of LM-300 Drill Rig and Pipe Handling System, 51

feasibility grant applications for MRS facility, 63,71

financial assistance to affected units of local government, 39

public safety training, 37

State of Nevada and affected counties, 37

financial assistance to affected units of local government, 2

financial statements (unaudited), 42, 45-46

MRS facility feasibility grants awarded

to Grant County, North Dakota, 71

to Mescalero Apache Tribe of New Mexico,

63,71

need for contingency plans, 72

Nuclear Waste Fund, 1

and analysis of fee adequacy, 1

and environmental programs, 3

Balance Sheets for FY 1989, FY 1988, tables 33-36

payment for disposal of defense waste, 31-32

payments-equal-to-taxes (PETT), 67

provisions for appeals in calculations of payments-

equal-to-taxes (PETT), 67

significance of development and evaluation activities on total-system of restructured program, 11, 14, chart 11

\section{Grant County, North Dakota, 71}

Hazardous Materials Transportation Uniform Safety Act of 1990, 37

Health, environment, and safety and site characterization, 42

Hydrology

and international cooperative activities with Switzerland, 68

models, 73

Idaho National Engineering Laboratory (INEL), 59

\section{INTERA, 31}

International cooperation, 14

and bilaterial agreement meeting, 4

DOE and Atomic Energy of Canada, 68

DOE and Switzerland's National Cooperative for the Disposal of Radioactive Waste (NAGRA), 68

International programs

potential use as models for U.S. programs, 43

Inyo County, California, 28, 39

J.K. Associates, 31

Lander County, Nevada

possible request for designation, 39

Licensing

desired criteria for repository, 2

Licensing Support System, 32

process for repository, 52

repository schedule, figures 54,55

schedule, figure 55

\section{Lincoln County, Nevada, 37}

\section{Litigation}

affected units of local government, 28

concerning air quality permit and underground

injection control, 40

environmental permits, $27-28$

and Management and Operating Contract, 31 
"notice of disapproval," 27

partnership with Nevada urged by Watkins, 28

petition by State of NV challenging scientific investigations, 27

rejection of challenges to site characterization efforts, 27

status of decisions, 27-28

Los Alamos National Laboratory (LANL), 5

Management and Operating Contract (M\&0), 31

\section{Meetings}

Radioactive Waste Management Committee and Bilateral Agreement, 4

Secretary of Energy Advisory Board Task Force on Civilian Radioactive Waste Management, $42-43$

Midwestern Office of the Council of State Governments, 66

\section{Mineral County, Nevada}

possible request for designation, 39

Monitored Retrievable Storage (MRS) facility assessment of siting feasibilility, 2

contractor capability, 31

description, 63,71

feasibility assessment grants, 41

and linkages to repository, 12

planned activities, 10

Preliminary Site Requirements and

Considerations for a Monitored

Retrievable Storage Facility, 64

\section{Morrison-Knudsen, 31}

National Academy of Sciences, 43

and origin of calcite/silica deposits, 49

Nuclear Energy Agency of the Organization for Economic Cooperation and Development

(OECD/NEA), 4, 58

National Energy Strategy, 42

Nuclear facilities, 69
Nuclear Regulatory Commission (NRC), 5, 9, $44,64,71,74$

and approval of study plans at the Yucca

Mountain site, 13

and licensing fees, 14

and Nuclear Waste Technical Review Board recommendations, 3

and support role of Licensing Support System, 32

Nuclear Waste Negotiator (see Office of the Nuclear Waste Negotiator)

Nuclear Waste Policy Act

and Nuclear Waste Fund, 1

Sections 114(e), 52

Nuclear Waste Policy Act, as amended, 37 modifications to licensing conditions for MRS facility, 12

payments-equal-to-taxes provision, 67

and Project Decision Schedule, 52

proposed amendment and permitting, 40 and report on scientific investigations, 5 training assistance provisions of Section 180(c), 6

Nuclear Waste Technical Review Board (NWTRB), 2, 5, 10, 28, 43, 74

and recommendations, $2-3,72$

review of DOE plans to seal and backfill underground excavations, 73

review of DOE quality assurance program for ESF, 13

technical recommendations on DOE program, 44

Nye County, Nevada, 37, 39

Office of Civilian Radioactive Waste

Management (OCRWM)

award of Management and Operating Contract, 31

development of alternatives, 29-30

draft strategy for training assistance, 37

institutional principles, 30

joint sponsorship of international workshop, 58

management principles, 29

overview of DOE program presented, 16

program planning, 10 
program requirements of standard contract for disposal, 12

and public trust and confidence, 43

and solicitation provision of MRS feasibility grants, 41

technical principles, 30

terms for acceptance and payment of disposal of defense high-level radioactive waste, 32

toll-free telephone number for information center, 68

\section{Office of Geologic Disposal, 41}

Office of the Nuclear Waste Negotiator

(ONWN), 2

and Memorandum of Understanding with DOE, 2

and Monitored Retrievable Storage (MRS)

facility, 10

negotiated agreements for siting MRS facility, 41

\section{Oversight, 44}

review of scientific studies, 43

role of States in regulatory program delegation, 40

\section{Performance assessment}

and decision-aiding methodology, 2

\section{Program planning, 74}

\section{Program schedule, 74}

\section{Prototype testing}

dry drilling and coring, 51

LM-300 drill rig, 74

Public health, safety, and environment, 71

Public information

available materials, $50,76-77$

800 number established, 50

importance of public education in energy, science, and the environment, 58, 76-77

and public confidence, 58

toll-free information number, 68

Public participation, 5, 6

importance of public concerns and involvement, 29-31 and input on administration of payments-equalto-taxes, 67

input on draft Mission Plan Amendment, 72

public trust and confidence, 42-43

workshop involvement, 14

Quality assurance

definition and application, 29

and site characterization, $5,13,16$

Public laws

Clean Air Act, 40

Clean Water Act, 40

Resource Conservation and Recovery Act, 40

RDA, 31

Reports

Acceptance Priority Ranking Report, 44

Analysis of the Total-System Life Cycle Costs for the Civilian Radioactive Waste Management Program, 11

Annual Capacity Report, 14

Annual Report to Congress, 32

comment period, 67

Draft Acceptance Priority Ranking, 44

importance of workshops in draft development, 67

ESF Alternatives Study, 74

Feasibility Study for Transportation Operations

System Cask Maintenace Facility, 32, 37

Historical Overview of Domestic Spent Fuel

Shipments-An Update, 69

Mission Plan Amendment (MPA), draft, 12, 29, 67,72

Notice of interpretation and procedures for payments-equal-to-taxes provisions, 67

Nuclear Waste Fund Fee Adequacy:

An Assessment, 1

Nuclear Waste Technical Review Board's

Fourth Report to the U.S. Congress and the

U.S. Secretary of Energy, 72

Nuclear Waste Technical Review Board's Third Report to the U.S. Congress and the U.S.

Secretary of Energy, 44

The Potential Use of Lead in the Waste Package for a Geologic Repository at Yucca Mountain, Nevada, 5 
Preliminary Estimates of the Total-System Cost for the Restructured Program: An Addendum to the Total-System Life Cycle Cost for the Civilian Radioactive Waste Management Program, 14

Progress Report on status of site characterization program, third semi-annual, 41

Project Decision Schedule, 52

Report to Congress on Reassessment of the Civilian Radioactive Waste Management Program, 67

Report to Congress on the Reassessment of the Civilian Radioactive Waste Management Plan, response to comments, 12

Second Report of the Nuclear Waste Technical Review Board, 3

Strategy to Provide Training Assistance as Required by Section 180(c) of the Nuclear Waste Policy Act, as Amended (preliminary draft), 6

\section{Repository}

and international studies, 68

\section{Research and Development}

Atomic Energy of Canada, Limited, 68 prototype dry drilling and coring equipment, 51 Switzerland's National Cooperative for the

Disposal of Radioactive Waste (NAGRA), 68

Risk assessment, 73

and performance assessment, 2

Risk communication, 58,76

Robbins Company, 73

Safety

during spent fuel handling and shipment, 3

Safety, health, and environment, 73

Schedule

assumptions for Monitored Retrievable Storage (MRS) facility, 52

baseline for development and operation of waste management system, figure 53

importance, 29

licensing, 52, figure 55

Monitored Retrievable Storage (MRS) facility, 52, figure 56
Project Decision, 52

projected acceptance of spent nuclear fuel, 14, 15 spent fuel receipt at repository, 52

transportation system, 52, figure 57

underground excavation, 72

Science education, 76

and decisionmaking, 58

educational programs and exhibits, 76

importance of institutional support, 30-31

and international workshop, 58

need for scientific literacy, 58

and nuclear power, 58

and public confidence, 58

Secretary of Energy Advisory Board Task

Force on Civilian Radioactive Waste

Management, members, 43

Site characterization, 5

activities planned for FY 1992, 10

Bow Ridge Fault, 49

Calico Hills, 74

challenges, 74

early emphases, 74

and effects of environmental studies, 3

importance of early underground excavation, 72

initiation of surface-disturbing activities, 49

investigations, 49

Midway valley, 49

need to proceed, 40

oversight by affected units of local government, 39

and payments-equal-to-taxes, 67

plan for environmental protection, 13

planned surface-based tests and boring activities, 74

procedures if potential repository site found

unsuitable, 52

Progress Report available, 41

proposed amendment to facilitate, 40

role of dry drilling and coring equipment, 51

and schedule, 72

status, 49,74

Trench 14, 49

trenching activities, 49, 74, figure 75

Site selection, 49

Site suitability

importance of scientific evaluation, 43 


\section{Soil Conservation Service, 3}

Southern States Energy Board, 66

\section{Spokesmen}

DOE Representatives

Bartlett, J.W., 4, 14, 58, 63

Gertz, C.P., 6

Isaacs, T.H., 4

King, G., 58

Watkins, J.W., 28, 42

Environmental Protection Agency

Habicht II, F.H., 40

Florida Public Service Commission

Wilson, M.M., 14

Nuclear Energy Agency

Kunihiko Uematsu, 14

Nuclear Regulatory Commission

Curtiss, J.R., 14

Nuclear Waste Technical Review Board

Deere, D.U., 14

Svensk Karnsbranslehantering

Bjurstrom, S., 14

University of Texas, Austin

Maxey, M., 14

\section{State of Nevada, $5,10,37$}

air quality permit issuance, 49

authority in site characterization activities, 40

financial assistance to, 10

and oversight role, 10

and participation in environmental studies, 3

partnership urged for Nevada and DOE, 28

and refusal to issue environmental permits, 13

\section{States}

Arizona and prototype drilling, 74

California and participation in environmental studies, 3

New Mexico, 71

North Dakota, 71

Utah

and prototype drilling, 74

selection as prototype drill site, 51

Swedish Nuclear Fuel and Waste Management Company, 4

Swiss National Cooperative for the Disposal of Radioactive Waste (NAGRA), 4, 58
Transportation (see also Reports)

Cask Maintainance Facility, 32, 36

cooperative agreements, 10

emergency planning, 66

exhibit available, 76

historical overview of spent nuclear fuel shipments, 69

implementation of Hazardous Materials

Transportation Uniform Safety Act, 37

institutional issues, 6

integrated role of transportation system with repository and MRS, 52

North American Standard for highway

inspection, 59

operational issues, 6

pilot inspection program, 66

pilot study

milestones for inspection procedures, figure 60

participants, figure 60

planned activities, 10

potential impacts on waste acceptance, 6

proposed five-step implementation strategy for

training assistance, 6

regional associations and issues, 66 ,

figure 66

risk perception, 77

schedule for development of transportation

system, figure 57

testing of inspection procedures, 59

training of public safety officials, 37

Transportation Coordination Group

Albuquerque, New Mexico meeting, 6, 37

TRW Environmental Safety Systems, Inc. (TESS), 31

U.S. Fish and Wildlife Service (FWS), 3 and Biological Opinion on desert tortoise, 5

Volcanism, 51,73

Waste Isolation Pilot Plant (WIPP), 16 and testing of vehicle inspection procedures, 59

Waste package

alternative materials research, 3 contribution to waste isolation, 3 and Engineered Barrier System, 3 and heater tests, 3 
Western Governors' Association, 59

Western Interstate Energy Board, 6, 66

White Pine County, Nevada, 39

Woodward-Clyde Consultants, 31

Workshops, 4 and draft Mission Plan Amendment, 14, 67, 72

Engineered Barrier System (EBS), 16

forum for DOE, NRC, and National Congress of American Indians (NCAI), 16

importance of workshops in formulation of draft Mission Plan Amendment, 67

International Workshop on Education in the Field of Radioactive Waste Management, 58 performance assessment workshop planned, 73

Strategic Principles Workshops, 67

waste management

Denver, Colorado, 14

Salt Lake City, Utah, 4

Washington, DC, 4

\section{Yucca Mountain Information Office, 5}

Yucca Mountain Project, 13

Yucca Mountain site, 5

affected units of local government, 39

Bow Ridge Fault, 49 determination of suitabilility impeded, 13

and environmental permitting, 13

and exploratory shaft facility design, 5

Facility Operations Center, 37

faulting studies, 49

and forum on Engineered Barrier System (EBS), 16

hydrology and isolation of waste, 49,51

legal requirement to study, 42

Midway Valley, 49

and origin of calcite/silica deposits, 49

and performance assessment, 2-3

potential sites for repository surface facilitites, 13

progress, 41

quality assurance program approved for new

activities, 13

recommendations

for engineered barrier system, 44,73

for evaluation of saturated zone, 44

seismic studies, 49

site characterization

schedule, 5,52

status, 74

and site suitability, $2,6,49,52$

and study plans for hydrological investigations, 13

tours to, 37

Trench 14, 49

volcanism studies, 51

Yucca Mountain Site Characterization Project Office, 41 